تاريخ الإرسال (10-02-2020)، تاريخ قبول النشر (05-05-2020)

اسم الباحث: ل د. محمد أحمد عبد الكريم الصمادي

وزارة التربية والتعليم -الأردن

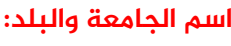

* البريد الالكتروني للباحث المرسل:

E-mail address: moh.abotamem@gmail.com

\title{
الإعلام وتأثيره في الثقافة الإسلامية
}

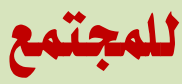

https://doi.org/10.33976/IUGJIS.29.2/2021/4

الملخص:

أعنيت هذه الدراسة بتحديد مصطلحاتها ذات الصلة المباشرة بموضوعها من خلال عرض لأبرز التعريفات عند أهل الفن ومناقشتها في ضوء الواقع، والخروج بتعريفات تعبّر عن حقيقة كلّ مفهوم ومصطلح -كالإعلام، والرأي العام، والثقافة الإسلامية، والمجتمع -بما يضمن وضوح معطيات الدراسة وحدود مادتها. وقد ناقشت أهمية الإعلام ودوره المؤتِر في ال حياة الشعوب, في الصراع بين الحق والباطل ( بين الأنبياء وأتباعهم والطغاة وأتباعهم )؛ من خلال تأثثيره في الرأي العام للجماهير عبر العصور, بما يسهم في تغيير ثقافات الشعوب والثقافة الإسلامية على وجه الخصوص, والتأثير فيها سلباً أو إيجاباً, مما يجعله أداة خطيرة مدمِرة بأيدي العابثين, وسلاحاً قوياً بانياً بأيدي المحسنين الخيّرينين الذين

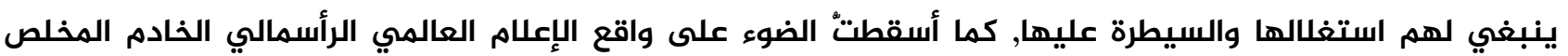
لمصالح الدول الكبرى, والمسيطر حالياً على العالم الإسلامي بما يحدثه من تغيرات خطيرة في الثقافة الإسلامية على مستوى التصوُرات, والقيم والقناعات, والنظم والمعايير؛ مما يستلزه عملاً حقيقياً واهتماماً جادّاً من الإعلاميين وصنّاع القرار المسلمين؛ لمعالجة ما أفسده الإعلام العلماني, وحماية الشعوب المسلمة من شروره, والسعي لتأسيس إعلام إسلاميّ هادف, يأخذ على عاتقه حمل رسالة الإسلام ورحمته للناس كافة.

\section{كلمات مفتاحية: إعلام -تأثير -ثقافة إسلامية -مجتمع -رأي عام}

\section{Abstract:}

This study is meant to determine terms that are directly related to its topic through presenting the prominent definitions by art specialists and discuss them logically. It also comes up with definitions that reflect the essence of each term such as media, public opinion, Islamic culture and society which ensures the clarity and the range of material included. The study discussed the effective role of media on people's life and in the conflict between good and evil. This appears through its influence on changing people's cultures( Islamic culture in particular)which makes it a dangerous and destructive tool if it was in the wrong hands. However, it can be a powerful and constructive weapon if it was implemented properly by the good people. The study also shed light on the truth of the international capitalist media which serves the interests of the major powers in the world that, in turn, controls the Islamic world and makes a lot of dangerous changes in terms of values, believes and standards. As a result, Muslim journalists and stakeholders should work hard to fix what the secular media has corrupted, and to establish a constructive Islamic media that takes the responsibility of spreading the merciful message of Islam.

|key words: Media - Islamic Culture - Society - Public opinion - Influence 
بسم الله الرحمن الرحيم، والصلاة والسلام على المبعوث رحمة للعالمين، سيدنا محمد وعلى آله وصحبه أجمعين،

خلق الله الخلق سبحانه، وخصَّ بني آدم بالتكليف؛ ليبلوهم أيهم أحسن عملاً، وتبعاً لذلك فإن الناس أصبحوا فريقين في

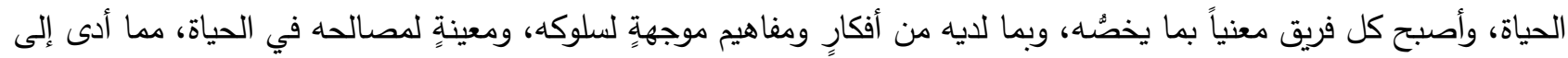
الصراع والنزاع على الأفكار والمصالح. وهذا ديدن البشر على مر العصور، لا فرق في ذلك بين حزب الله وحزب الثيطان، ولا أدل على ذلك من جُهد الأنبياء عليهم السلام في دعوتهم لهداية الناس، وإخراجهم من الظلمات إلى النور، بالدعوة إلى الله تعالى بالجهاد تارة، وبمقارعة الحجة

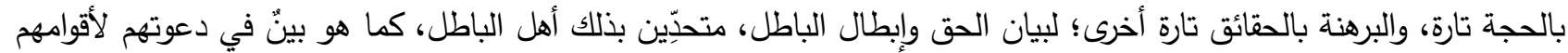

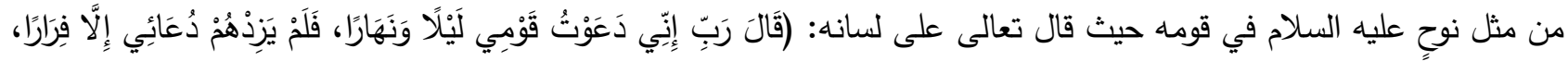

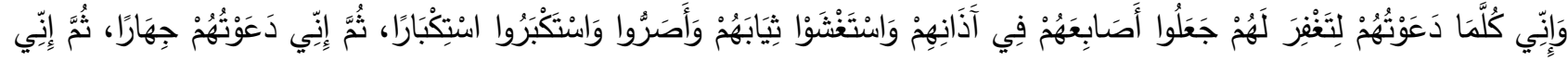

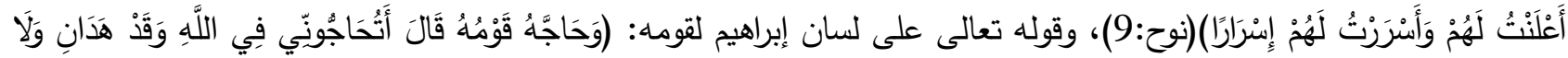

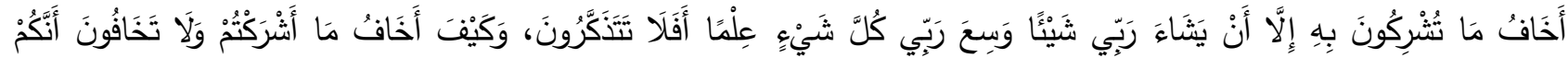

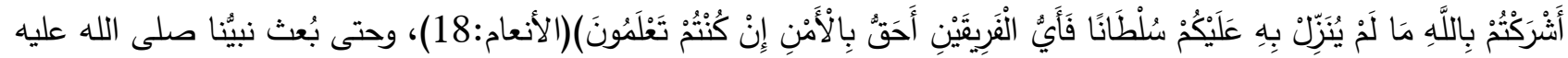

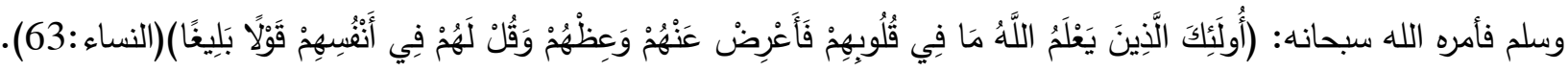
أهمية البحث ومبرراته: 1. تسليط الضوه على أهمية الإعلام ووسائله، ودوره المحوري في تثكيل الرأي العام، وبيان أثره الخطير في حياة الثعوب المسلمة ومجتمعاتها، ودق ناقوس الخطر . 2. هيمنة الدول الغربية الكبرى على الإعلام وتفوقها في تسخيره لتضليل الثعوب واستباحة ثرواتها واستهداف ثقافاتها وموروثاتها الحضارية لاسيما الثعوب المسلمة وحضارتهم؛ مما يستدعي ضرورة كثف وسائل الكفار وأدواتهم في استهدافهم للثقافة الإسلامية

3. الكثف عن طريقة الأنبياء بمخاطبة الجمهور؛ لتغيير الثقافة الفاسدة والأديان الباطلة والتصدي للثبهات المضللة؛ لتكون

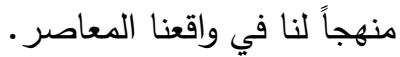
4. لفت أنظار المخلصين من المسلمين لهذه الأداة الخطيرة؛ لعلهم يحسنون تسخيرها في خدمة الحق، ونشر هداية الإسلام في 
6. هل للثقافة على العموم والثقافة الإسلامية على الخصوص تأثير في المجتمع؟

7. ما مدى تأثر المجتمع والتقافة الإسلامية بالإعلام المهيمن؟

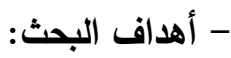
1. تحديد مفهوم الإعلام في الإسلام وفي غيره.

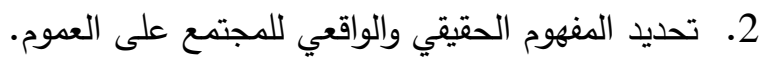

3. تحديد مفهوم الثقافة على العموم، والثقافة الإسلامية.

4. معرفة أثر الإعلام في الثقافة والثقافة الإسلامية على وجه الخصوص. 5. معرفة كيفية تأثير الإعلام في الثقافة والمجتمع لاسيما الثقافة الإسلامية.

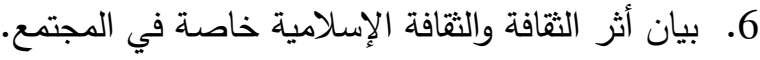
7. بيان مدى تأثر الثقافة الإسلامية وتغير المجتمع بالإعلام.

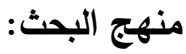

1. المنهج الوصفي الاستقرائي: استقراء تعريفات العلماء في مصطلحات الدراسة الأساسية، ووصف مفاهيمها ومتعلقاتها اللازمة لموضوع الدراسة؛ كمفهوم الإعلام لغة واصطلاحاً وواقعه ووسائله، ومفهوم المجتمع وأركانه وطبيعته، ومفهوم الثقافة والثقافة الإسلامية، ومفهوم الرأي العام.

2. التحليلي النقدي: تحليل التعريفات والمصطلحات والمفاهيم، وتعهدها بالنقد والمناقشة في ضوء واقعها وأقوال العلماء وأدلة الباحثين والمقارنة العقلية سعياً لمعرفة حقيقتها. 3. الاستتتاجي: استقراء أفكار العلماء وأقوالهم ومعلومات الباحثين في التراث وواقع الإعلام، واستتتاج النتائج ورصدها. الاراسات السابقة:

هناك العديد من الدراسات التي تتاقش موضوعات الدراسة أو تتناول بعض موضوعاتها كالكتب الخاصة بالإعلام مثلا، وكتب الإعلام الإسلامي مثل:(العلاقات العامة والإعلام من منظور علم الاجتماع للدكتور حسين رشوان)، (الإعلام السياسي والرأي العام للدكتورة عزيزة عبده)، (منهج الإعلام الإسلامي في صلح الحديبية للدكتور سليم حجازي).

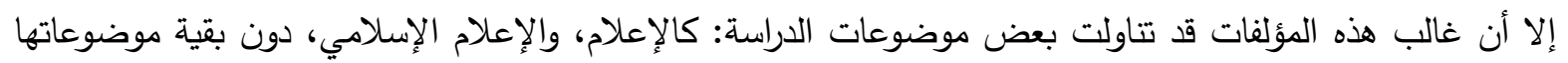
والعلاقات فيما بينها، وهناك الكثير من المقالات والأبحاث العلمية التي تتاولت بعض موضوعات الدراسة مثل: (بحث: الإعلام العربي المعاصر وأثره في ضياع الجيل وهزيمة الأمة للدكتور يوسف العظم)، (بحث: الإعلام العربي الموجَّه للآخر والحوار بين الآني الإسلام والغرب للدكتور محمد قيراط)، غير أنها ناقثت بعض آثار الإعلام على الجيل المسلم على وجه العموم، ولم ترضي

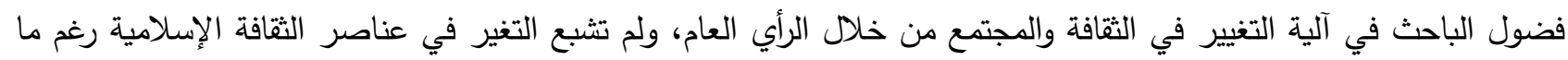
أفادت هذه الدراسات في موضوع الدراسة من فائدة جليلة مقدَّرة. لذا جاءت هذه الدراسة لجمع شتات موضوعاتها في دراسة واحدة، ودراسة ما بين موضوعاتها من علاقات، مع محاولة الإضافة على جها الباحثين بما فيه الإفادة. خطة البحث: قُِّيّتت هذه الدراسة إلى مقدمة، وثلاثة مطالب، وخاتمة على النحو التالي:

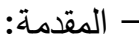
- المطلب الأول: مفهوم الإعلام. - المطلب الثاني: مفهوم المجتمع. 
المطلب الثالث: تأثير الإعلام في الثقافة الإسلامية.

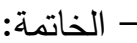

قائمة المراجع والمصادر

المطلب الأول: مفهوم الإعلام.

المسألة الأولى: تعريف الإعلام.

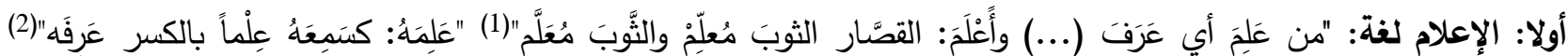

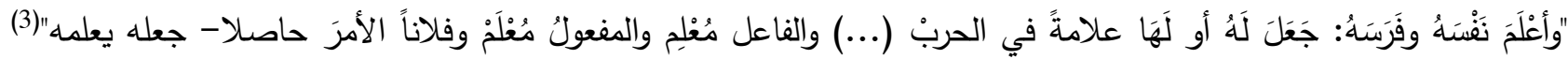

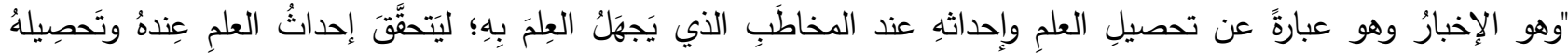

وما يعنينا من هذه المعاني أنها ذات صلة مباشرة بالدلالة الاصطلاحية من معنى الإخبار ، والمعرفة، ووضع علامة دالةٍ

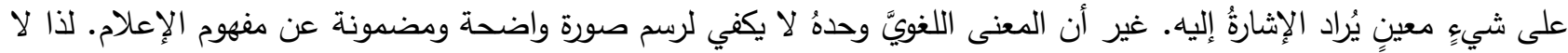

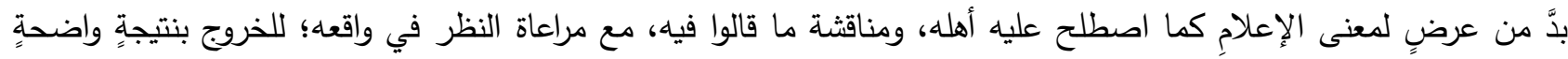
جلية، كما سيأتي في الفرع التالي من المسألة.

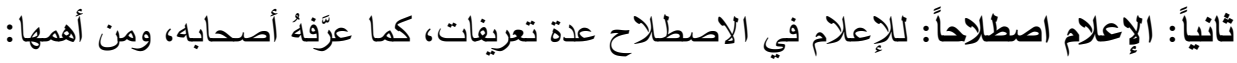

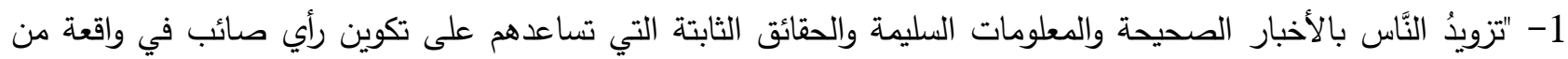

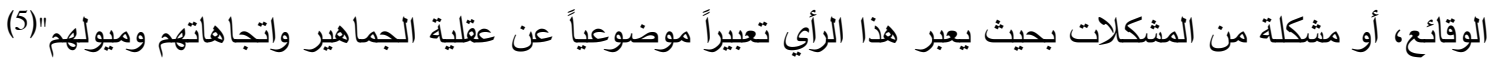

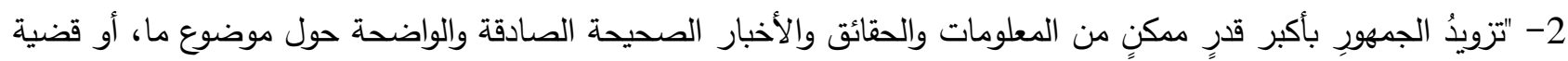
هامة، أو أي أحداث أو أي مجريات تثغل تفكير الرأي العام سواءً على الصعيد الداخلي المحلي أو على الصعيد الخارجي

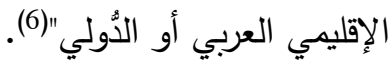

3- "كافة أوجه النشاطات الاتصالية التي تستهدف تزويد الجمهور بكافة الحقائق والأخبار الصحيحة والمعلومات السليمة عن القضايا والموضوعات والمشكلات ومجريات الأمور بطريقة موضوعية، وبدون تحريف؛ بما يؤدي إلى خلق أكبر درجة من المعرفة والوعي والإدرالك والإحاطة الثاملة لدى فئات جمهور المتلقين للمادة الإعلامية بكافة الحقائق والمعلومات الموضوعية الصحيحة عن هذه القضايا والموضوعات؛ بما يسهم في تتوير الرأي العام وتكوين الرأي الصائب لاى الجمهور في الوقائع والموضوعات والمشكلات المثارة المطروحة"(7). 4- "التعبير الموضوعي لعقلية الجماهير ولروحها وميولها واتجاهاتها في نفس الوقتات(8).

$$
\text { 1- ابن منظور . لسان العرب (ص418). }
$$

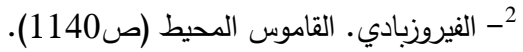

3- مصطفى. المعجم الوسيط (ص 624). 4- الحنفي. المعجم الثامل لهصطلحات الفلسفة (ص279).

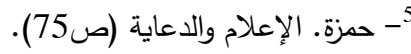

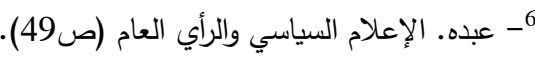
7- سعد. الاتصال والرأي العام (صلئ16). 8- سعد. الاتصال والرأي العام (ص16) العان.

88 IUG Journal of Islamic Studies (Islamic University of Gaza) / CC BY 4.0 
5- "نشر الحقائق الثابتة الصحيحة، والأخبار والمعلومات السليمة الصادقة، والأفكار والآراء، والإسهام في تتوير الرأي العام وتكوين الرأي الصائب لدى الجمهور، أو جماهير المؤسسة الداخلية والخارجية في الوقائع والقضايا والموضوعات والمشكلات المثارة والمطروحة؛ وبحيث يعبر هذا الرأي تعبيراً موضوعياً عن عقلية الجماهير واتجاهاتهم وميولهم"(9).

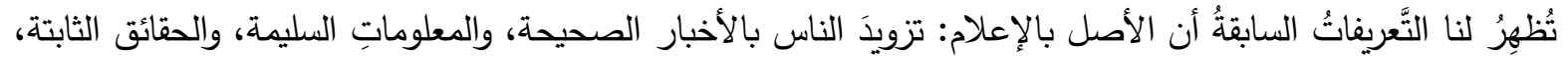

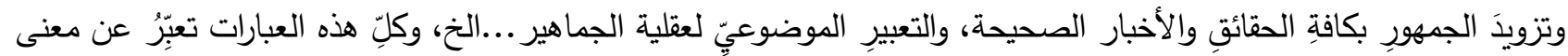
واحد: هو قصد تكوين رأي صائب لدى الجماهير حول الأحداث والوقائع بتجرد من الهوى و تمام الموضوعية والتعبير عن عقلية الجماهير واتجاهاتهم وميولهم. وتفرد بعضها بقصره على القضايا والمجريات التي تثغل تفكير الرأي العام، أو بتثكيل الإعلام أكبر درجة من الوعي لدى الجمهور ...الخ. وبالنظر إلى واقع الإعلام، نجده إن كان موضوعياً ناقلاً للحقائق فهو فقط ناقلٌ لحقائق القائمين عليه، وموضوعيّ بما يفهمون عن الموضوعية، فالموضوعية والصدق صفة للقائمين عليه - إن صح ذلك - لا صفة لله، فهو ينقل ما يريدون من الحقائق، وما يحددون من الموضوعي، بدليل ما ذكره هربرت في كتابه ( المتلاعبون بالعقول) الذي ترجمه عبد السلام رضوان

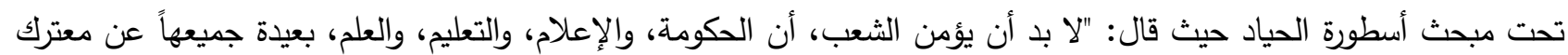
المصالح المجتمعية المتصارعة، وتبقى الحكومة، والحكومة القومية بوجه خاص، بوصفها ركيزة أسطورة الحياد، فهذه الأسطورة تقرض مسبقاً الإقناع الكامل باستقامة وعدم تحزب الحكومة بوجه عام وعناصرها المكونة: الكونغرس، النظام القضائي، والرئاسة.

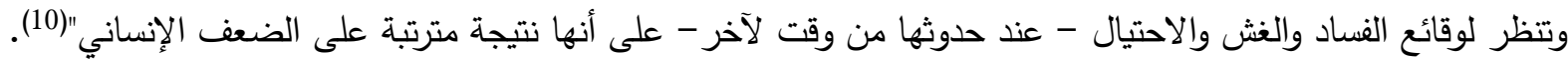

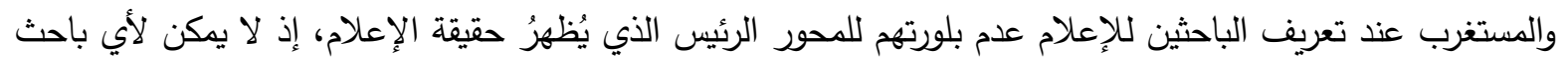

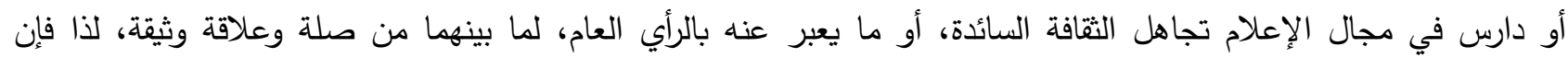

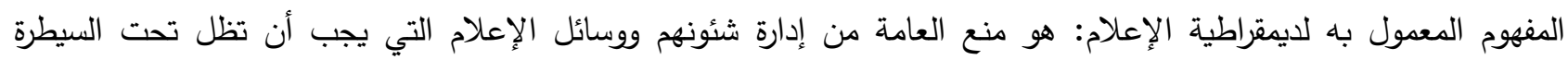

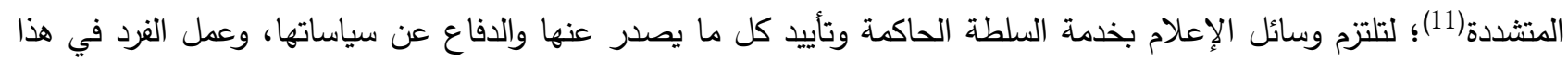

الإعلام امتيازٌ مرتبط بتأييده للنظام الحاكم (12).

وقد ذكر الهاشمي في كتابه: "ولكننا نستخدم مصطلح الإعلام الدولي على اعتبار أن الإعلام يعني الدقة والموضوعية

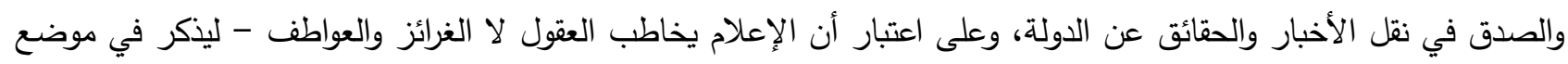

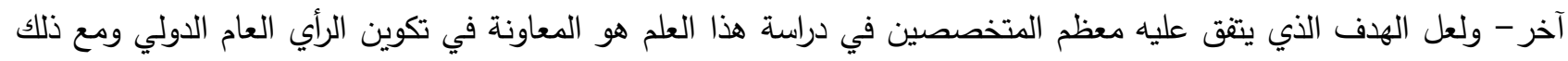

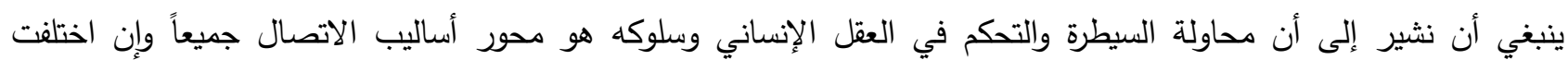

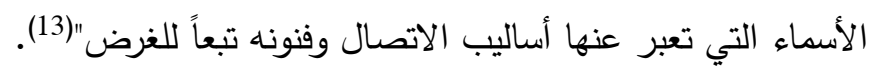

9- رشوان. العلاقات العامة والإعلام من منظور علم الاجتماع (ص 248).

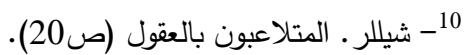

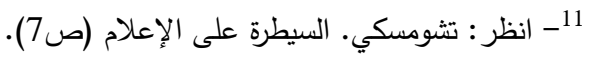
12 12 انظر : أبو زيد. الإعلام والديمقراطية (ص232). 
فكيف يتسنى لنا وصف الإعلام بالموضوعية والمصداقية في نقل الحقائق والأخبار كما تصفه التعريفات السابقة؟ أما

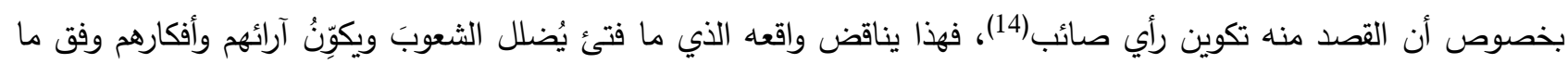
يراه صاحب النفوذ والسلطة، ووفق ما يراهُ القائمين عليه، كما أن واقعه ييرز اهتمام الإعلاميين بالقضايا والأحداث المؤثرة في الرأي العام التي تخدم أهداف الدولة وتطلعات متتفذيها في حين يُغفلون أو يتجاهلون القضايا الهامة، والمجريات المؤثرة التي تخدم حياة الثعوب وتتوافق مع أفكارهم وميولاتهم.

\section{وفي هذا المقام يفترض توضيح إثكالية الإعلام الموجه وغير الموجها تونه}

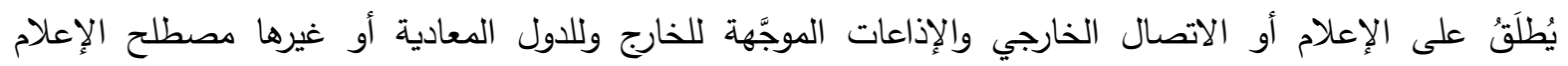

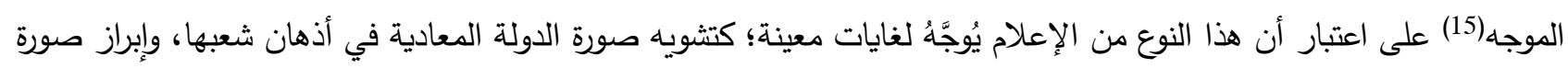

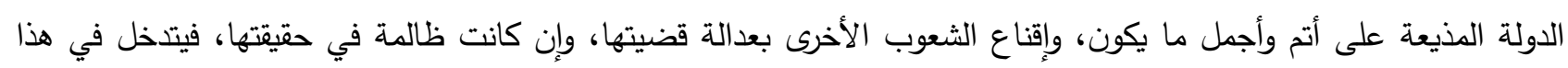

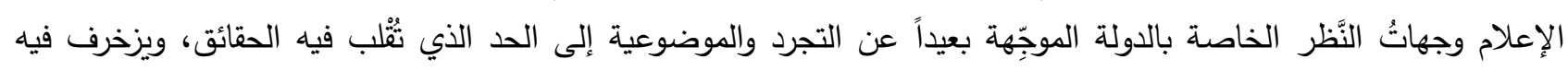
القول؛ للتمويه على الجمهور المستهدف بما يخدم أهداف الدولة في الاتجاه الذي تريد. ويطلق على الإعلام الداخلي الذي يبث برامجه لداخل الدولة وشعبها بالإعلام غير الموجه على اعتبار أنَّهَ إعلام يتسم

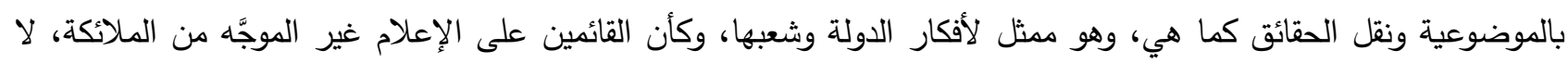

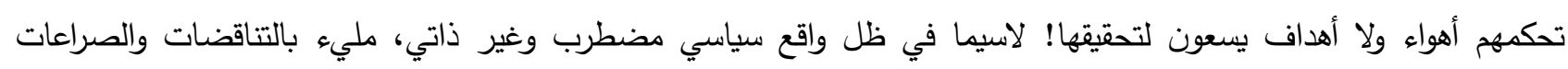
المحلية والعالمية.

من هنا بات من المستحيل وجود إعلام موجه وغير موجَّه، فكل الإعلام موجَّه، لأن القائمين عليه يخضعون للجهة التي

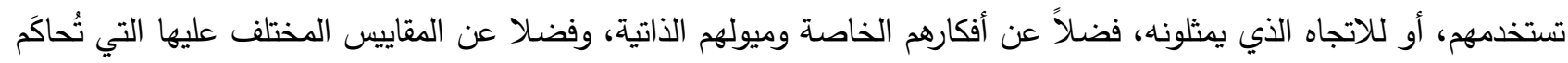

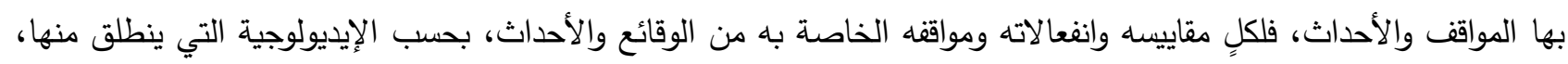

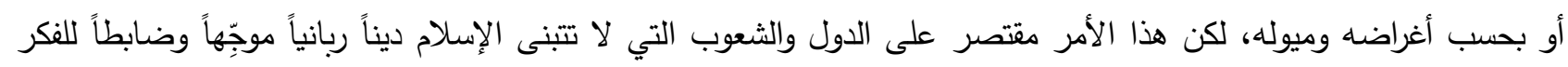

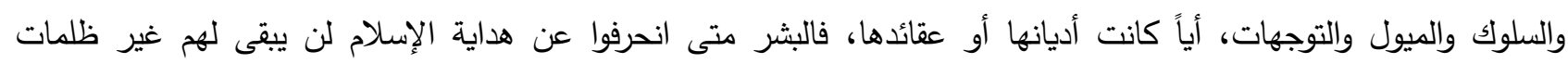
الضلال.

أما في ظل الإسلام فالصدق والموضوعية متحققة لا محالة، في أدنى تصرف من تصرفات الفرد إلى أعلى تصرف من تصرفات المجتمع والدولة بما في ذلك الإعلام؛ لأن الأفكار والتصورات، والميول والتوجهات، والمعايير والأهداف مصدرها لإنهات الواحد

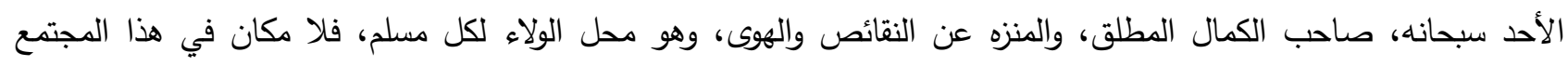
للكاذب أو الدجال، فهو محاسب منبوذ، من القريب قبل البعيد، ومن الفرد قبل المجتمع والدولة، فلا فكرٌ ولا تصور ولا ميول ولا ولان

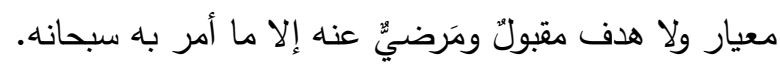


ومن الجدير هنا الإثارة إلى نظرة الإسلام للإعلام، فقد قال الدكتور محيي الدين عبد الحليم: "إذا استعرضنا التعريف

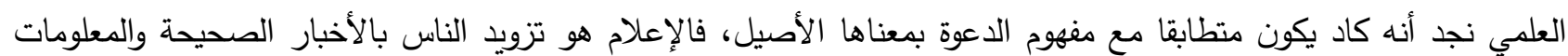
الصحيحة والحقائق الثابتة بهدف تكوين رأي عام وصائب في واقعة من الوقائع وحادثة من الحوادث أو مشكلة من المشكلات" (16)، غير أن الدعوة إلى الله في حقيقتها لا تقتصر على مجرد نقل الأخبار والمعلومات بل هي أعم وأشمل من الإعلام؛ لكونها جهود

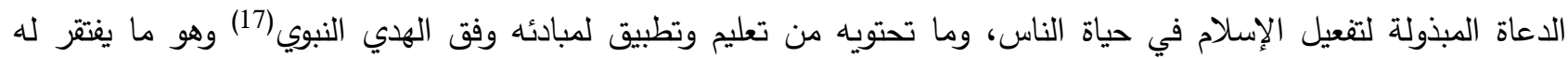
الإعلام ولو اتفتت معه في جانب منها في قصد توجيه فكر الأمم والتأثير في الثقافة السائدة للشعوب كلاً وفئ وفئ أهدافه الخاصة.

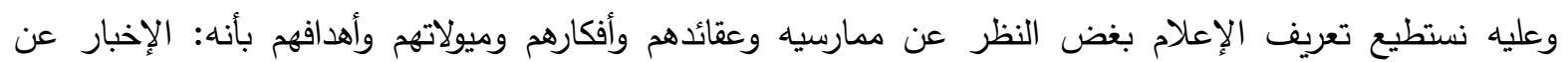

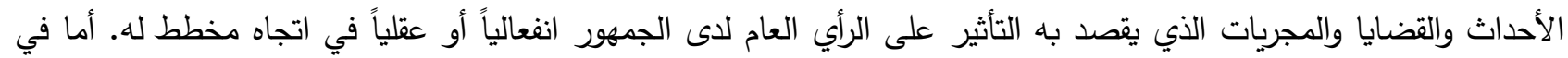
الإسلام: فهو الإخبار عن الأحداث والقضايا والمجريات بمصداقية وموضوعية، الذي يقصد به تصويب الرأي العام لاى الجمهور

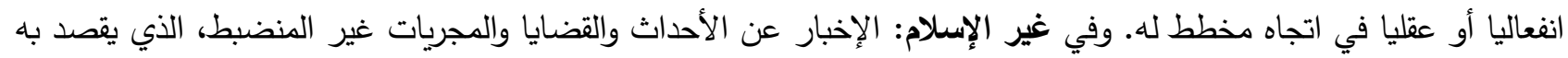
التأثير على الرأي العام لدى الجمهور انفعاليا أو عقليا في اتجاه مخطط لهاه.

المسألة الثانية: الإعلام وأهدافه. أولا: الإعلام في الإسـلام وأهد(فه:

إن الإعلام في الإسلام مبني على قوة الحجة والبرهان، وصدق اللهجة وفلامداحة وفلاحة التعبير وتتوع الخطاب، فلا مكان فيه

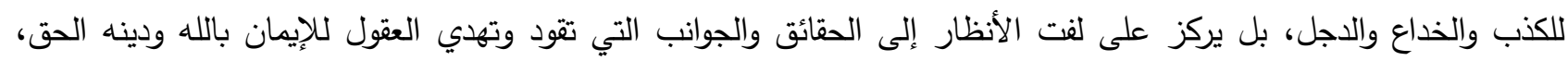
ويتبنى الارتفاع بالمستوى الفكري والنفسي وإثاعة الفضيلة والقيم الرفيعة.

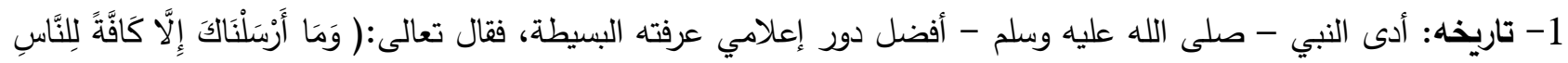

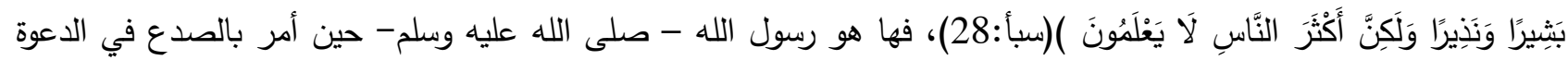

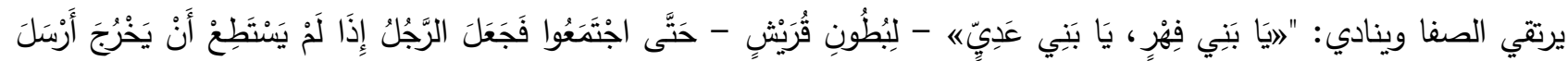

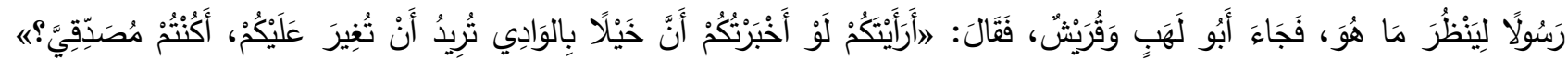

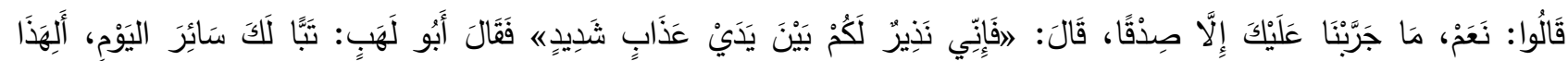

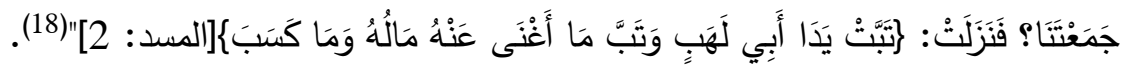

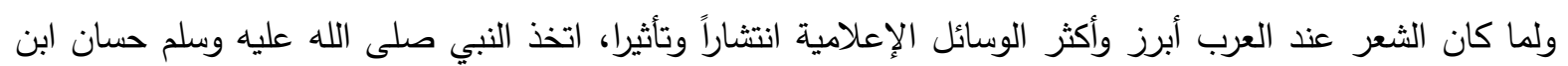

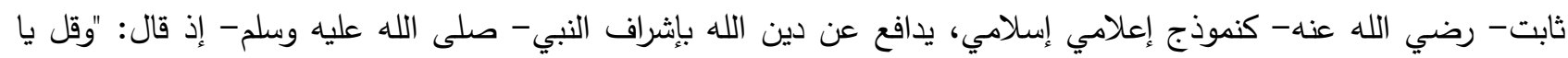

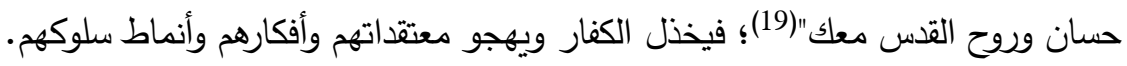
وكذلك أمره صلى الله عليه وسلم لهصعب ابن عمير رضي الله عنه بالهجرة للمدينة- قبيل إقامة دولة الإسلام فيها-

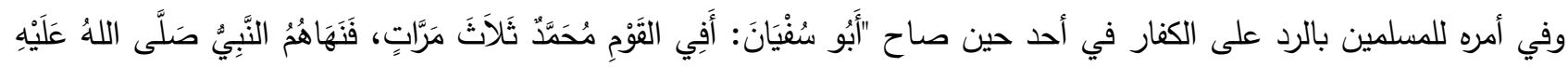

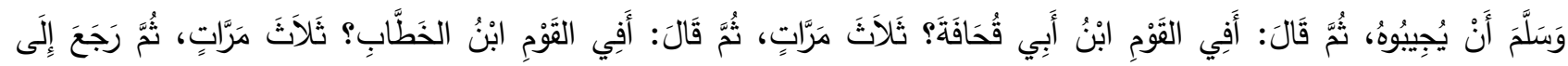

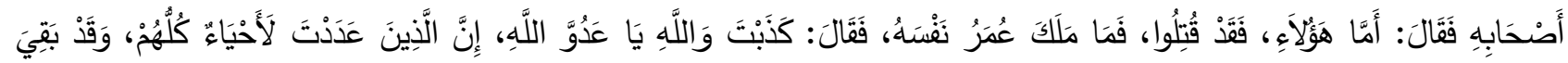

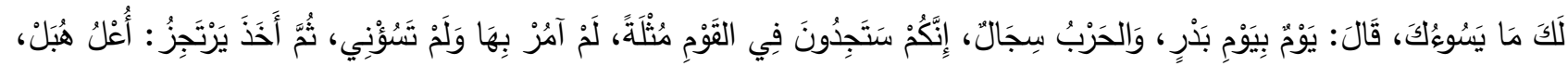




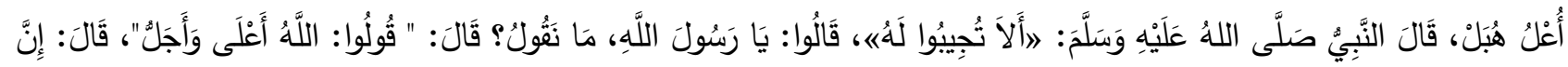

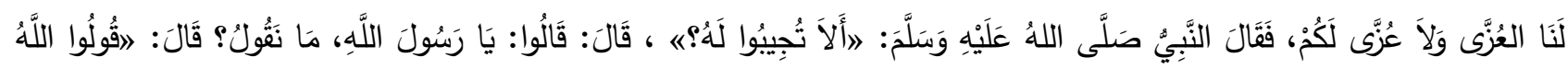

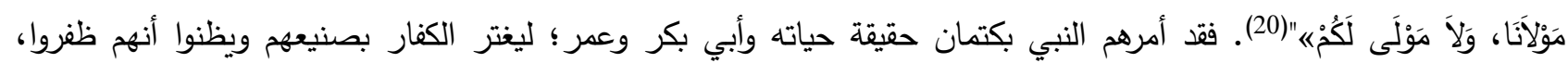
وعندما أراد أبو سفيان غيظهم بقوله؛ أمرهم النبي بالردّ عليه وعدم السكوت على قوله واستغزازه. وقد أرسل النبي صلى الله عليه وسلم الرسل إلى كسرى وقيصر والمقوقس يدعوهم ومن ورائهم للإسلام، وقد بقي النبي - صلى الله عليه وسلم- داعياً إلى الله سبحانه مبلغاً وناشراً لرسالة ربه حتى أتاه اليقين.

2- خصائص وسمات الإعلام الإسلامي(21):

أ. المصداقية: فهي أهم المبادئ التي لابد منها لنجاح العملية الإعلامية؛ ليكون الإعلام ناجحا ومؤثراً وقادراً على التغيير للأفضل

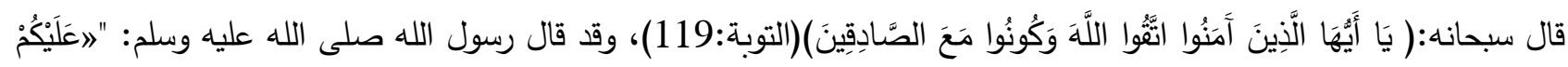

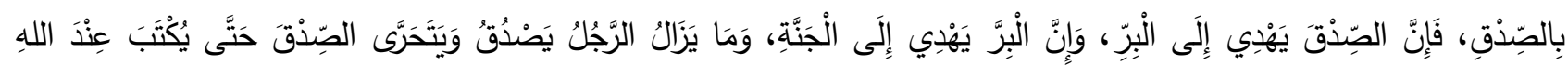

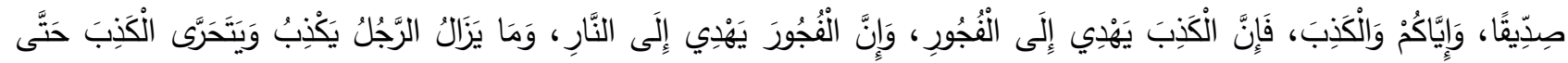

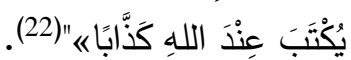
ب. الواقعية: وهي مسألة هامة أيضا لنجاح الإعلام وتأثيره؛ لأن الإعلام إذا لم يكن متتاولاً لقضايا ومشاكل المجتمع أصبح بعيداً

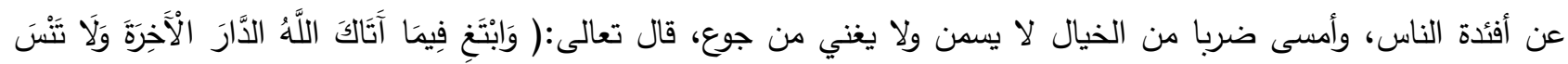

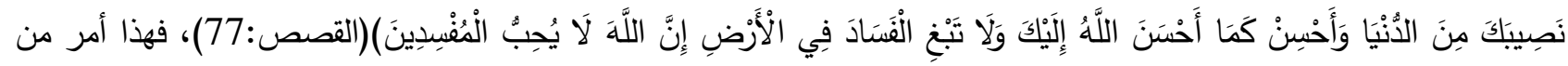

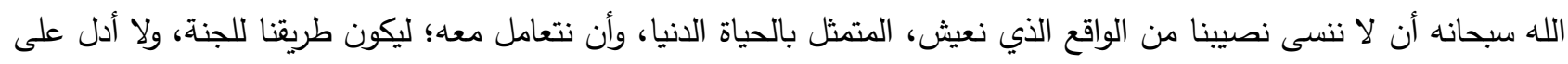

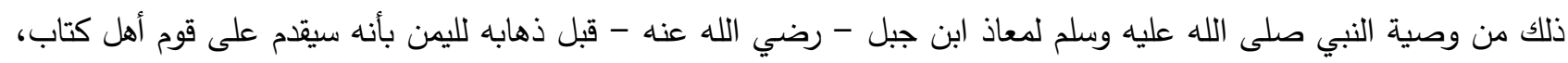
فأول ما يدعوهم إليه هو التوحيد(23). ج. الدعوة للحق: فالحق في الإعلام الإسلامي هو الهدف والمرجع المتمثل بوحي الله تعالى والدعوة للإِسلام، فلا محل لأهواءٍ ولا

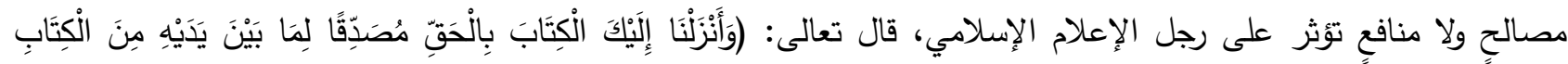

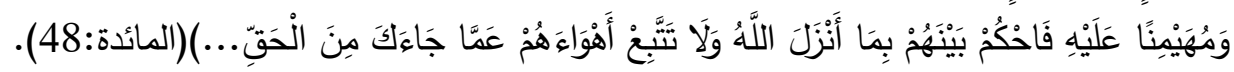
د. الوضوح وعدم الغموض: وهذا لضمان وصول الرسالة للمتلقي لتعمل عملها فيه، وقد برز هذا في تتويع النبي - صلى الله

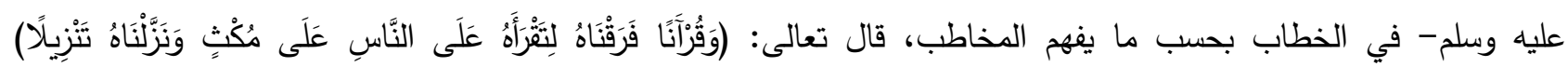

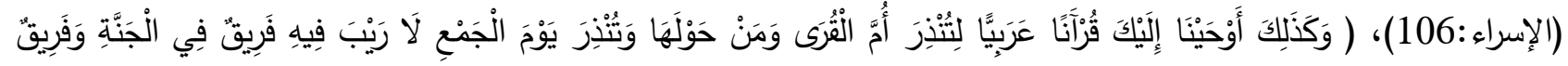

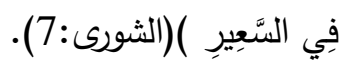
هـ الثمول: فهي تشمل جميع القضايا التي يعيشها الإنسان في السياسة والاقتصاد والاجتماع...الخَ، قال تعالى: (وَيَوَْمَ نَبْعَثُ فِي

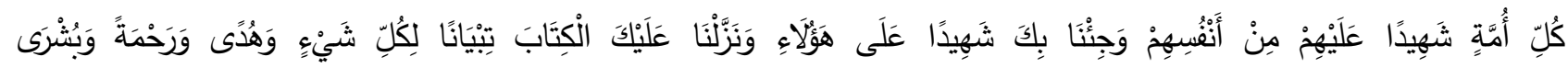

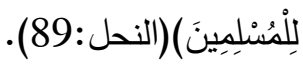

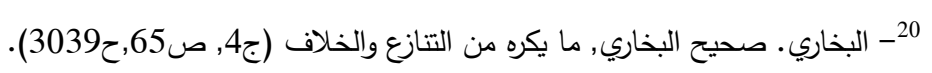

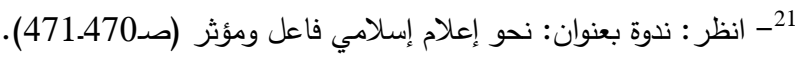

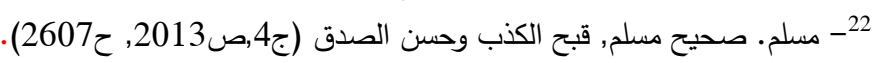

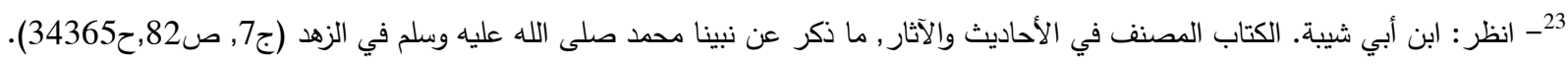
92 IUG Journal of Islamic Studies (Islamic University of Gaza) / CC BY 4.0 
و. عالميته ومراعاته للمسلم والكافر ولجميع شرائح المجتمع وفئاته: فهو يراعي الكبير والصغير، رجالاً ونساءً، مسلمين وغيرهم،

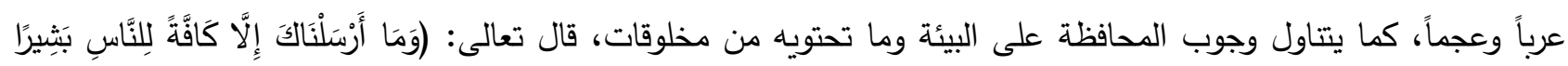

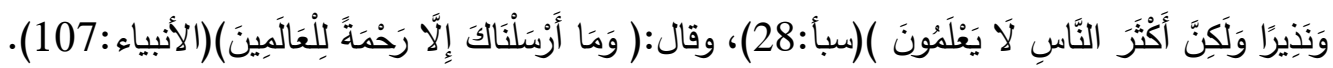

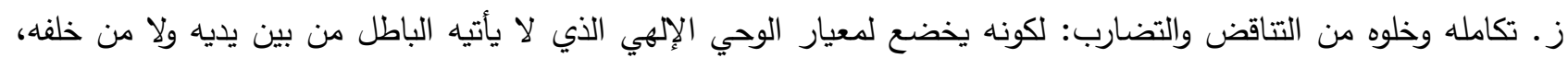

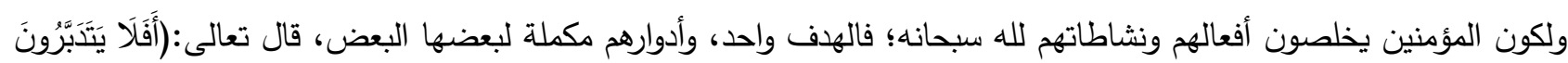

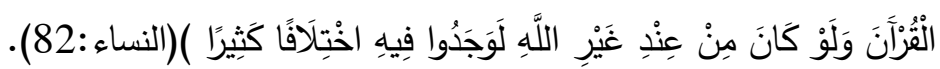

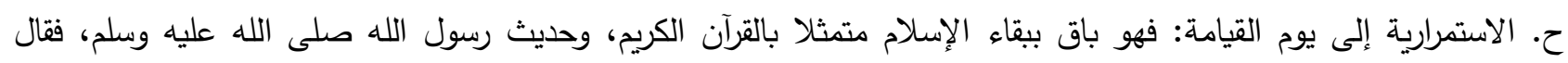

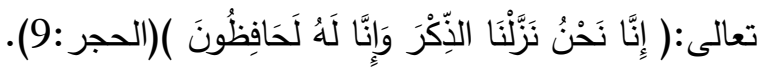
3- أهداف الإعلام الإسلامي: تتلخص أهداف الإعلام الإسلامي بما يلي: أ. نشر الرحمة والخير للعالم، من خلال حمل الدعوة الإسلامية، وبيان حقيقة الإسلام عقيدة وشريعة، قال تعالى: ( وَمَا أََْْلْنَكَكَ

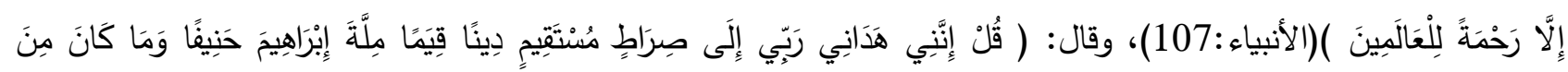

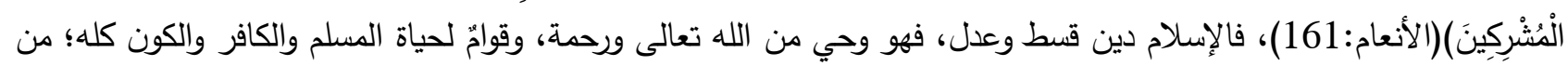
خلال سياسة الأرض بأمر الله وهديه سبحانه. ب. بيان زيف العقائد والأفكار والتشريعات الوضعية، وعجزها عن تحقيق العدالة وحل مشاكل البشرية، قال سبحانه:( أَمِ اتََّذُْوا

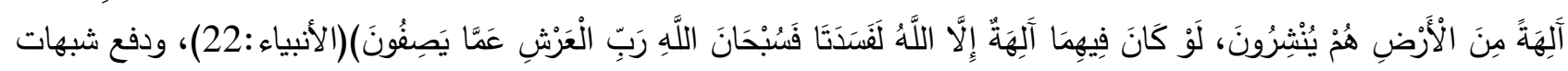

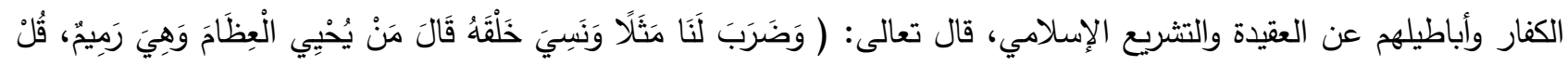

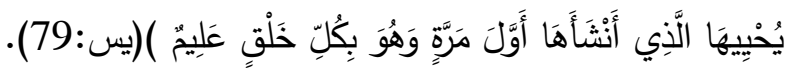
ج. تثقيف المجتمع الإسلامي، وتزويده بالأحكام الصحيحة على الأحداث والوقائع وفق معيار الإنى الإسلام، وتحصينه من الأفكار

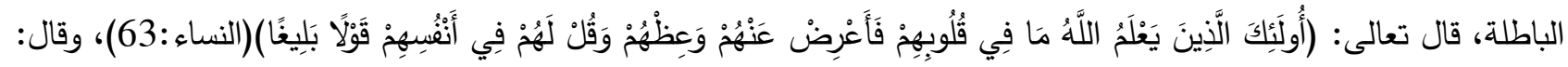

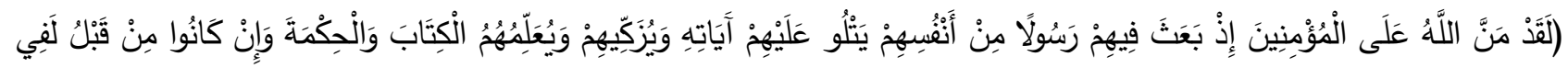

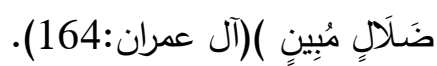
د. نقل الأحداث والوقائع في العالم ككل بمصداقية النية وموضوعية متتاهية، مع توجيه الأفهام لفهمها فهماً صحيحاً وفق الثقافة

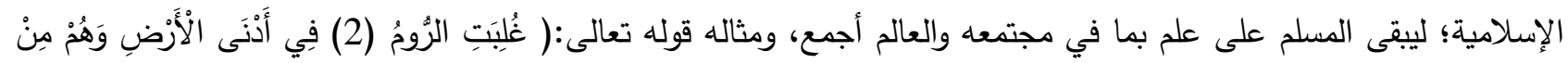

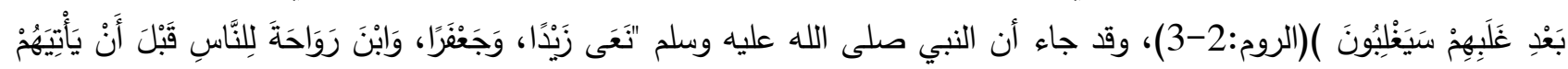

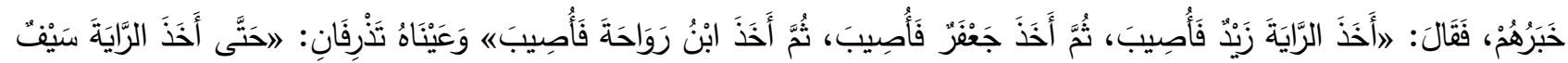

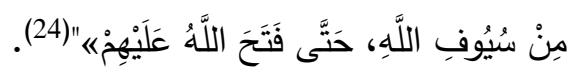
هـ إظهار حقيقة الحياة الإسلامية وطبيعتها، وجعل الهيمنة للقيمة الروحية في المجتمع المسلم؛ التي تكفل السعادة المطلقة

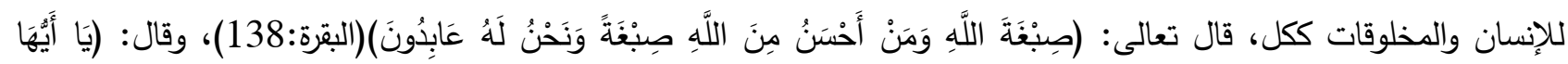

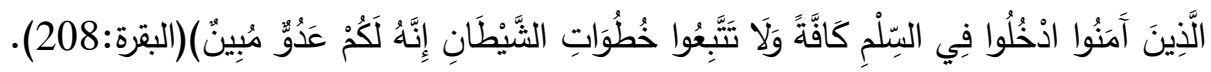

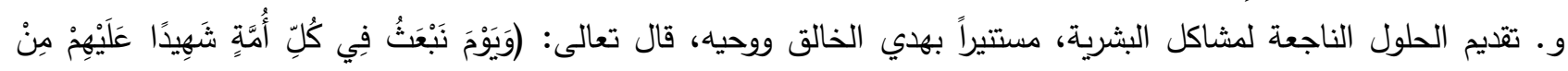

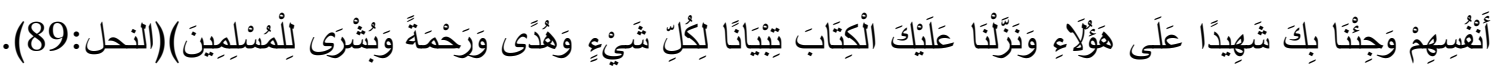
ثانياً: الإعلام عند غير المسلمين وأهدافه: 
أما أهل الباطل، فواقع الأداء الإعلامي عندهم غير مضبوط بقيد أو شرط، انسجاماً مع فكرة الحرية ومبدأ الغاية تبرر الوسيلة، عمدتهم الخداع والدجل والتمويه في سبيل تحقيق أهدافهم ومصالحهم، والترويج لأفكارهم ومعتقداتهم وسلوكياتهم الباطلة دون اكتراثٍ لما قد يسبيونه من طمس لحقائق الأشياء وواقعها، أو من تدمير لعقول الشباب وسلوكياتهم، أو هدم لحضارات الأمم وثقافاتها ومعتقداتها.

1- تاريخ الإعلام عند غير المسلمين وسماته: ومن قديم الزمن والكفار يحاولون التشكيك في الدين الحق وأهله، فقال تعالى:

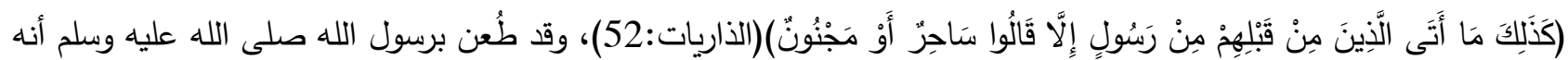

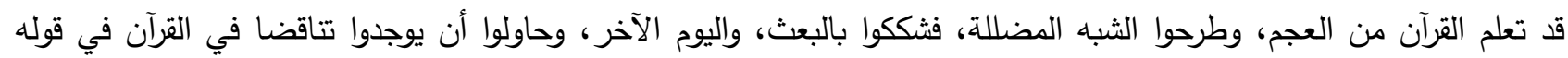

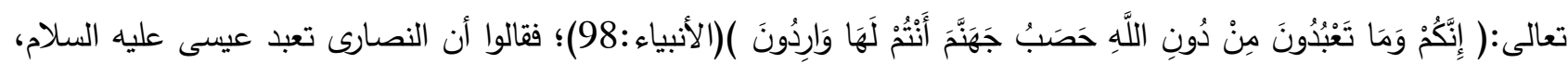

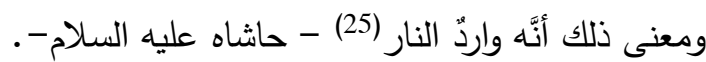
وبعد ذلك تولى اليهود والنصارى هذه المهة؛ فأنشأوا في القديم دوراً للوضع بالحديث الثريف، مهنتها بث الأحاديث

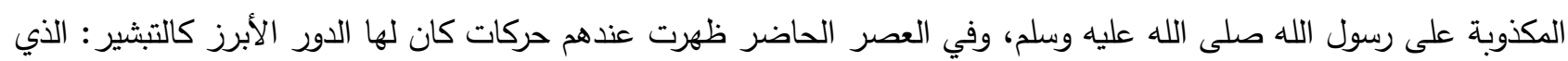
يحرص على تتصير الثعوب، من خلال وسائل دنيئة في استغلال حاجة الثعوب الفقيرة والمعدمة للغذاء والدواء والتعليم، فيبنون التهني

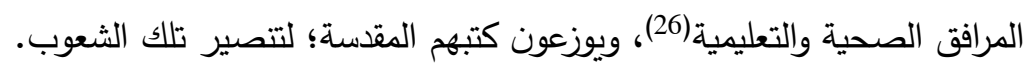
وكذلك حركة الاستشراق: التي تتخصص في دراسة عقائد أهل الشرق وعلومهم وعاداتهم وتقاليدهم وتراثهم الفكري والمادي

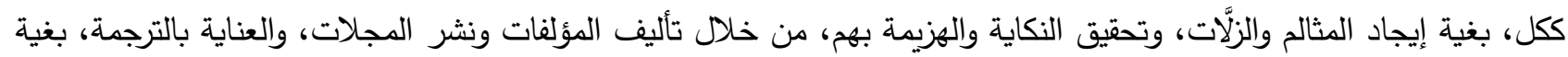

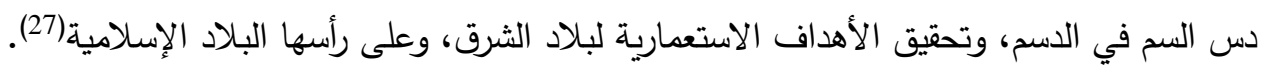

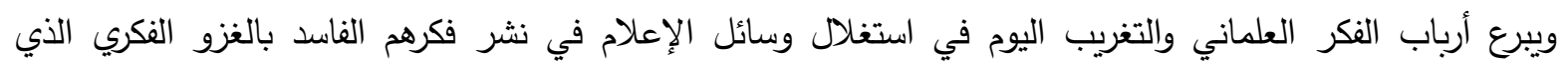

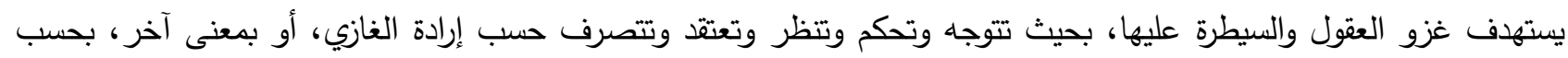

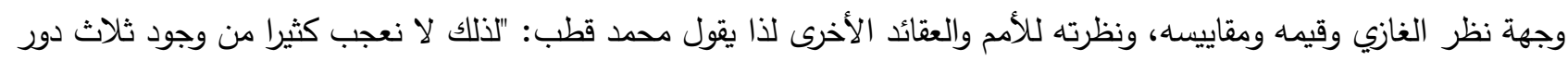
صحفية كبيرة لبنانية مسيحية مارونية في القاهرة، وإن كان السؤال يظل باقياً: لماذا اختار أولئك المسيحيون المارونيون اللئل اللبنانيون

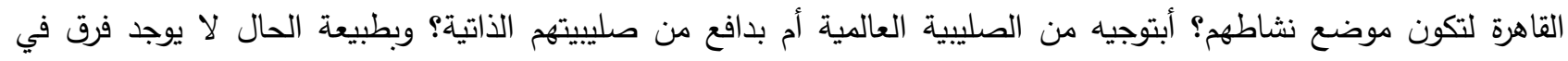
النهاية بين هذا الوضع وذاك، فالقنوات الصليبية تلتقي كلها في النهاية في مجرى واحد (...) فهي تمتدح الإسلام وتمدح رسوله مناكية العظيم صلى الله عليه وسلم (...) فالإسلام يمتدح بما يرضي عواطف المسلمين، نعم. ولكن لا يتحدث عنه كنظام حياة وشريعة حكم، وحينما تتاقش المشاكل القائمة في مصر أو في العالم الإسلامي، فلا يقدم لها الحل من شريعة الإسلام، ولا حتى من روحله . .إنما تقدم الحلول - كما سنرى - من التجربة الأوروبية ومن (الحضارة الأوروبية) بل أكثر من ذلك (...) إنما هو حديث مناسبات

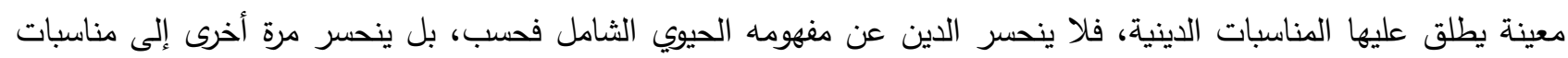
عارضة في حياة المسلم"(28). 
ويروي المطبقاني في حديثه عن التغريب في التعليم قول لويس عن أثر المدرسين العسكرين ومقصدهم في البلاد

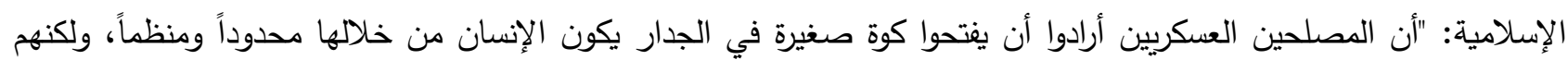
سمحوا بفيضان اخترق آلاف الثقوق مسبباً الدمار وواضعاً بذور حياة جديدة"(29)، فما هي بذور الإنياة الإنيان الجديدة التي قصدها؟ إنها الأفكار والقيم ووجهات النظر الغربية التي تفرز التصرفات وأنماط العيش الغربية بما فيها من إباحية ومادية. وقد ذكر هدار في معرض حديثه عن حال المسلمين بعد التوسع والفتوح: "نلك أن المسلمين بعد امتداد حركة الفتوح صادفوا ملاً وديانات مختلفة كانت تقف عقبة في سبيل انتشار الإسلام وتقدمه في البلاد المفتوحة، وكان أصحاب هذه الديانات من السريان والنصارى والفرس والزردشتيين والحرانين والصابئة وغيرهم قد هضموا التراث اليوناني وتمثلوه أحسن تمثيل، كما مُرِّنوا على أساليب الجدل والمحاكاة لإحاطتهم بوسائل المنطق اليوناني، عندئذ أحس المسلمون بحاجتهم لوسائل هذا المنطق وإلى ولى التدريب على أساليب الجدل؛ للدفاع عن الإسلام ضد خصومه وإقناع الهنكرين له من أصحاب الديانات الأخرى"(30).

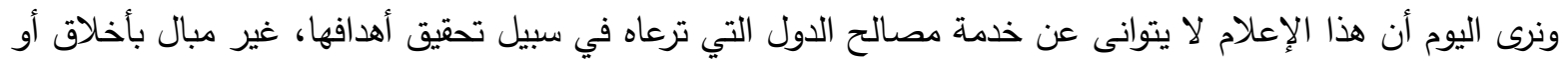

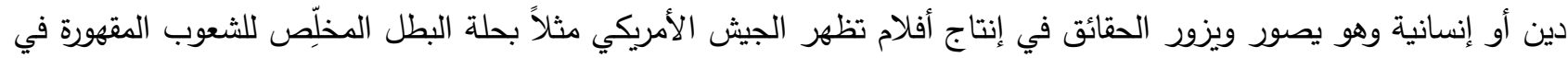
العراق وأفغانستان وغيرها...، وما فتئ هذا الإعلام يستحدث الوسائل والأساليب باسم العولمة؛ ليجعل العالم كالقرية الصغيرة

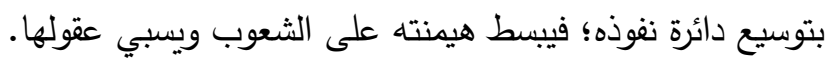
ويتلخص بذلك، أن الإعلام الغربي القائم على الغزو الفكري والثقافي، يستهدف ثقافات الأمم وعقائدها؛ لتغيير مقاييسها

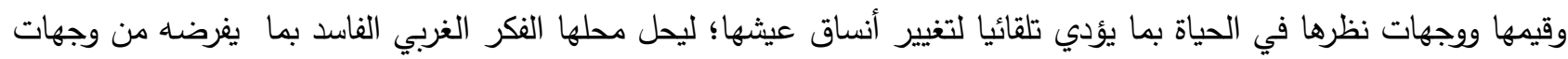
نظر ومعايير في الحياة؛ ليقى الغرب الكافر هو المهيمن على الأمم بفكره وقوته يسومها سوء العذاب، يمتص دمائهائها ئها دون شعورها

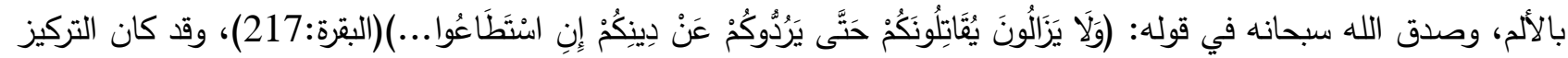

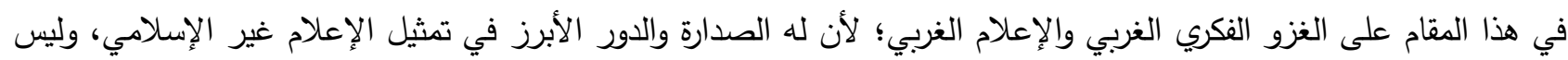
المقصود حصر الإعلام غير الإسلامي فيه وحده. 2-أهداف الإعلام عند غير المسلمين:

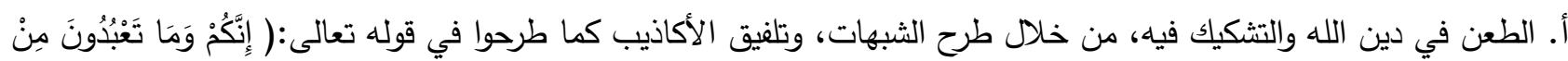

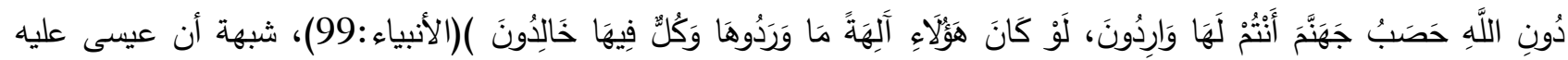

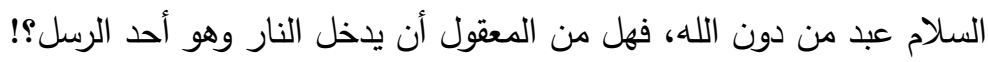
ب. تثويه العقيدة الإسلامية وتلويثها بالفكر الغربي، والسعي لتتكر المسلمين لدينهم، وإشاعة الفساد الخلقي وإبهارهم بالمدنية

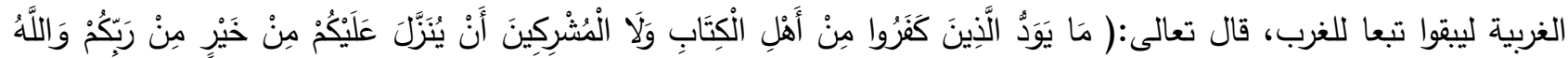

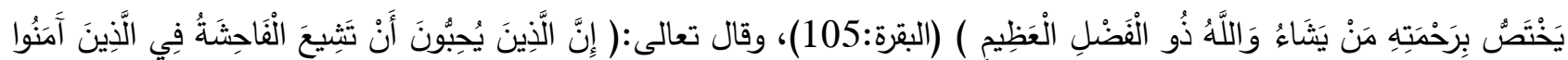

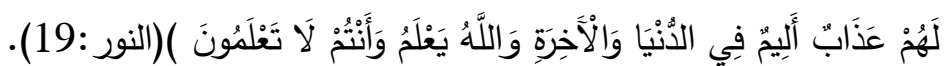
ج. تثويه الثعوب المسلمة وإبقائها تبعاً لها؛ لتمسي كثعوبهم بلا مقصد أو هدف أسمى يحدو أذهانها، بل منتهى اهتمامها السمر

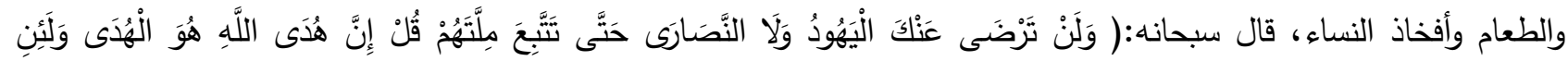

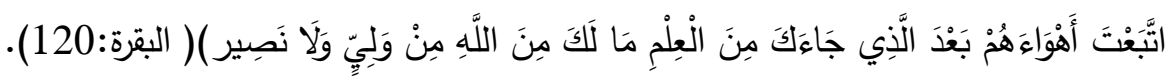

29- المطبقاني. الاستثراق والاتجاهات الفكرية في التاريخ الإسلامي (دراسة تطبيقية على كتاب برنارد لويس) (ص 487).

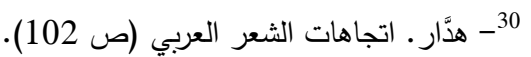


د. تثكيل مظلة إعلامية تحمي شعوبهم من خطر التعرف على العالم الخارجي، وما به من حقائق وأفكار ووقائع قد يسبب معرفتها خطراً على أصحاب النفوذ السياسي والاقتصادي العلماني والرأسمالي وسياساتهم؛ لتبقى مستعبدة تساق سوق الأنعام (31). ويتضح مما سبق أن هذا النوع من الإعلام هو موضوع دراسة هذا البحث لكونه المهيمن والسائد في وقتتا الحاضر ؛ لما

$$
\text { العيشألة المسلمون اليوم من ضعف وهوان على الناس. }
$$

أولا: الاتصال الثخصي: وهو التواصل الثخصي المباشر دون وسائل مادية أو وسائط نقل يستعان بها في عملية الإرسال، وقد تلخص في الثعر والخطابة في القديم، ويندرج تحت هذه الوسيلة الأحداث المفتعلة والمرعبة، والإثاعات المعدَّة لما فيها من الإنسان إيماءات ورأي جمعي.

وقد ذكر د.عرفان: "أن مسألة القضاء والقدر والصفات الإلهية ظهرت في الإسلام من تعاليم الكنيسة النصرانية ونفوذ أساتذتها المتكلمين - ويتابع - تحاشا أهل الكتاب الجدل العلني، وأخذ بعضهم يدخل الإسلام ليعملوا من خلاله، فكانوا يثيرون الأسئلة من داخل المسلمين (...) كما هيأ جو الأمن والحرية الذي عاشه النصارى في ظل دولة الإسلام إمكانية الجدل ودخول

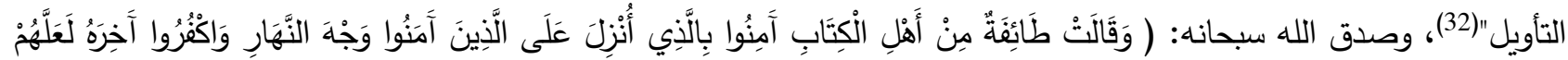

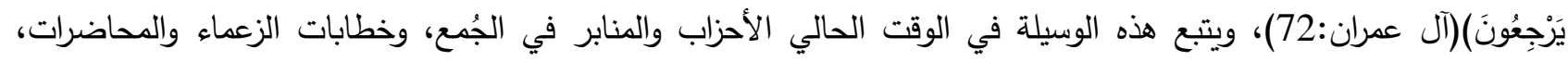
والمؤتمرات والمسارح السياسية والاجتماعية، والنثرية والغنائية. وتبرز أهمية التواصل الثخصي في كونه لا يحمل دليلاً ملموسا على أصحابه في الفكر الذي يتواصلون فيه، وفي قوة تأثيره على الجماهير على مر العصور، سواءً كان في الحق كما في دعوة النبي - صلى الله عليه وسلم - لقومه، أو في الباطل

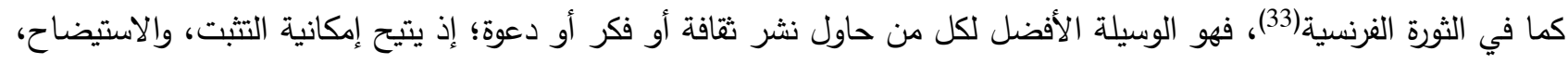
والاستفسار ، وهو يعتبر أقدم وسائل الإعلام ظهوراً.

ثانيا: الاتصال المرئي والمسموع والمقروء (34):

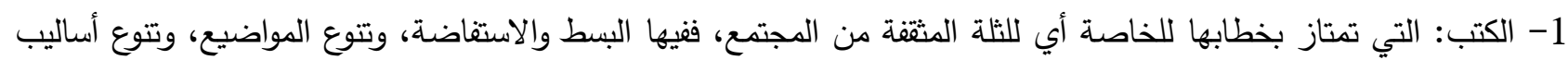
الخطاب من شعر ونثر وقصة ورواية بحيث تلبي جميع الميول والرغبات، ونتيجة لذلك تُحقق قوة إقناعية عالية. 2- الصحافة: التي تحتوي الجرائد والمنشورات والمجلات التي تتميز بسهولة الوصول إليها وأرشفتها للرجوع لها في في أي وقت يختاره القارئ؛ فيراجع ما يريد مراجعته بالسرعة التي يريدها، وهي ذات انتشار أوسع من الكتب وتغطي جمهورا أكبر، إلا أنها أقل تأثيراً

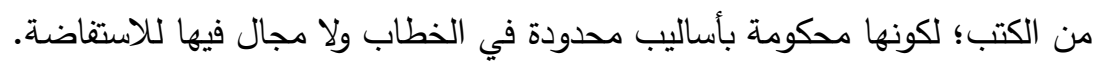
3- الراديو : بما يحويه من أخبارٍ وأغانٍ وأفكارٍ ، وما يتميز به من مساحات مكانية وجماهيرية واسعة يغطيها، متخطياً حاجز الأمية والحواجز الجغرافية؛ حيث يصل للصغير والكبير، والمتعلم وغيره دون أدنى جهد من المستمع الذي يستطيع الاستماع له خلال العمل، كما أن الراديو يعطي مجالاً للتصور والتخيل والتنكير أكثر من التلفاز .

31 -32- انظر : شيللر . المتلاعبون بالعقول (ص20).

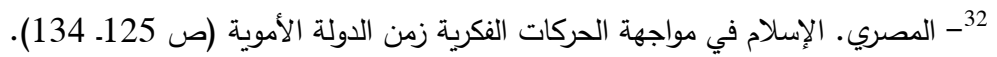

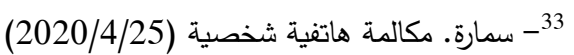
34- انظر : الدبسي. الإعلام الإسلامي (الأهداف والوظائف) (ص 15). وجبارة.

96 IUG Journal of Islamic Studies (Islamic University of Gaza) / CC BY 4.0 


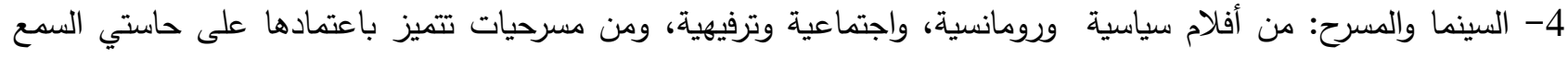
والبصر ، وجمعها بين الرؤية والصوت والحركة والألوان؛ فتملك على المشاهد نفسه وتأسر وجدانه وتتلاعب بعواطفها، إلا أنها أقل

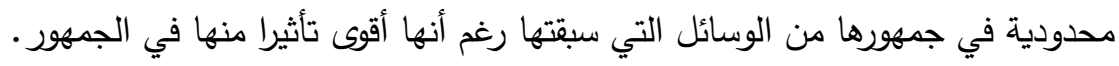
5- التلفاز واللواقط: تلك الوسيلة الأخطر على الإطلاق، التي تجمع بين قوة السينما والمسرح بالتأثير على الجمهور ، وسعة

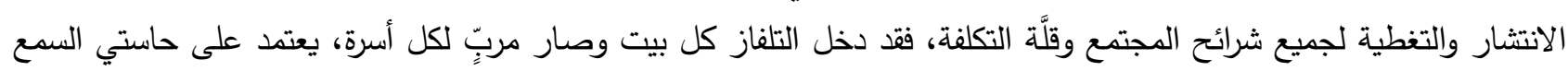

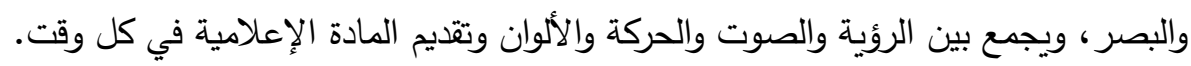

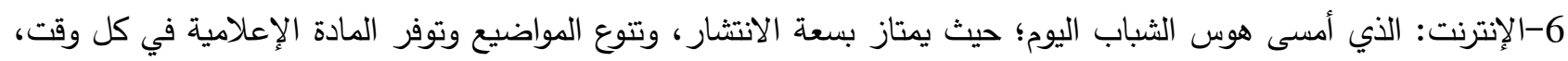

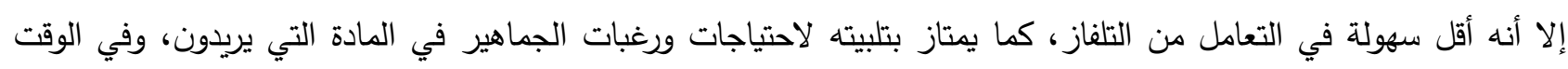
الذي يرغبون، من ثقافة وترفيه وغيرها...الخ. وفي الواقع إن وسائل اتصال الإعلام المرئي والمسموع والمقروء قد أصبحت في في الصدارة ودخلت كل بيت وقرية، وأمسى

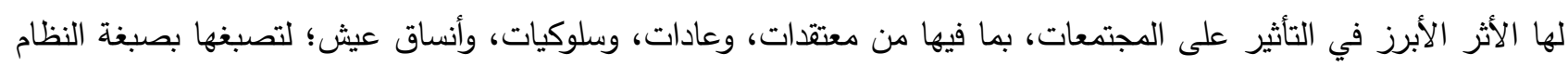
العالمي الجديد تحقيقا لمفهوم العولمة. وتظهر نظرة الإسلام لوسائل الإعلام بشكل عام من خلال ما نزل من قرآن في الثعر والثعراء(35)، تلك الوسيلة

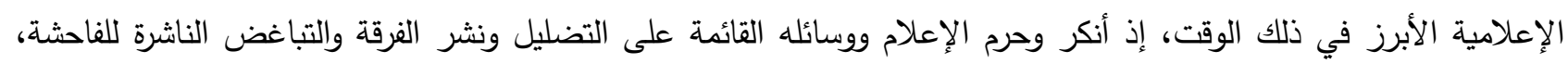

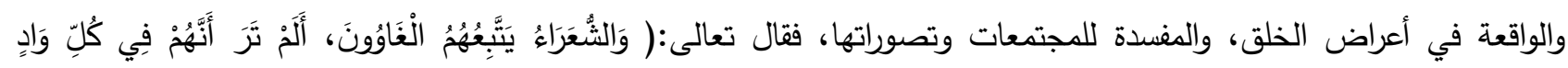

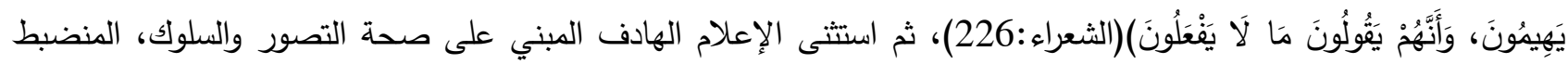

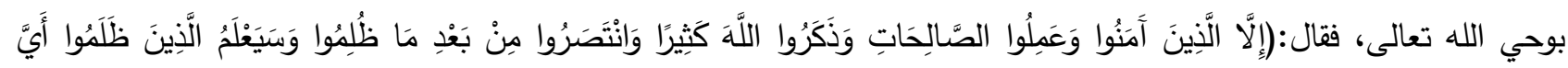

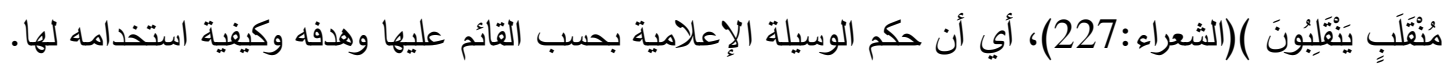
المطلب الثاني: مفهوم المجتمع. المسألة الأولى: تعريف المجتمع.

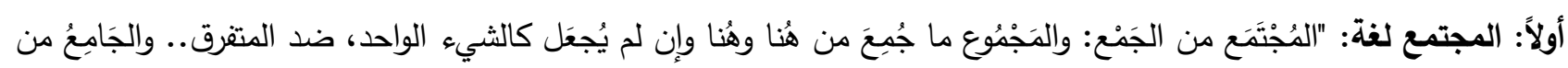

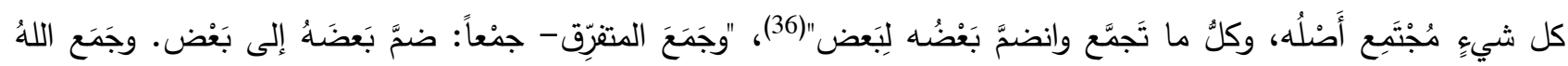
القلوبَ ألَّفها" (37). تبين مما سبق أن كلمة مجتمع تدل على تأليف المتفرق، ومكان الالتقاء بالأصل والاتفاق، ومكان المخالطة ونشوء

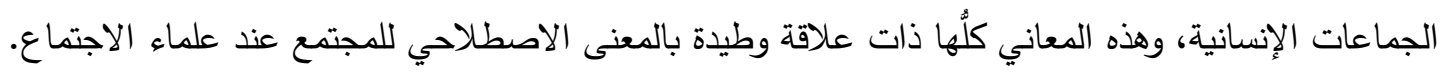
ثانياً: المجتمع اصطلاحاً: عرِّف المجتمع بعدة تعريفات، أبرزها:

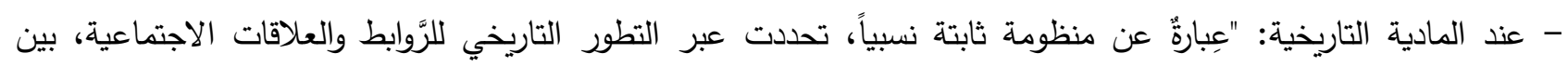
جماعات من الناس بمعنى الطبقة، تعزز وجودها قوة العادات والتقاليد ثم القوانين القائمة على أسلوب معين للإنتاج" (38). - "حصيلة منظومة المؤسسات والنظم والتنظيمات الاجتماعية"(39).

$$
\begin{aligned}
& \text { 35- انظر : الماوردي. النكت والعيون (ج4, ص190). } \\
& \text { 36- الفيروزبادي. القاموس المحيط (ص النس 710). }
\end{aligned}
$$

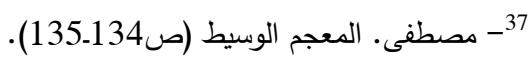

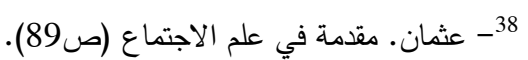

$$
\begin{aligned}
& \text { 39- عثمان. مقدمة في علم الاجتماع (ص90) في علمان. }
\end{aligned}
$$

97 IUG Journal of Islamic Studies (Islamic University of Gaza) / CC BY 4.0 
- "النسق المكون من العُرف المنوع والإجراءات المرسومة، ومن السلطة والمعونة المتبادلة، ومن كثير من التجمُعات والأقسام وشتى وجوه ضبط السلوك الإنساني والحريات"(40). - "جميعُ العلاقات بين الأفراد وهم في حالة تفاعل مع منظمات وجمعيَّات لها أحكام وأسس معينة. لكن المجتمع يشمل جميع

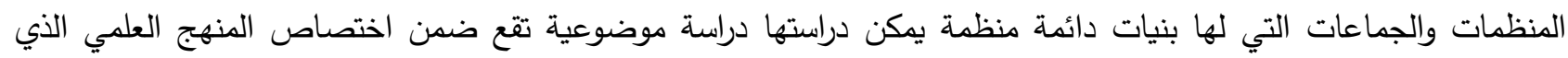
يسير عليه عالم الاجتماع"(41). يظهَرُ مما سبق أن هذه التعريفات متأثرة بوجهات نظر أصحابها عن الحياة، كما ظهر في تعريف الماديين للمجتمع الذين عزوا نشوء العلاقات والروابط الاجتماعية إلى أسلوب معين للإنتاج، غير أن هذا الأمر غير مستغرب؛ لأن الإنسان يفسر

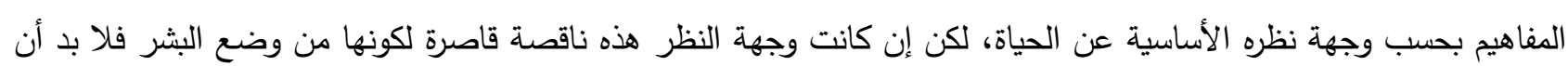

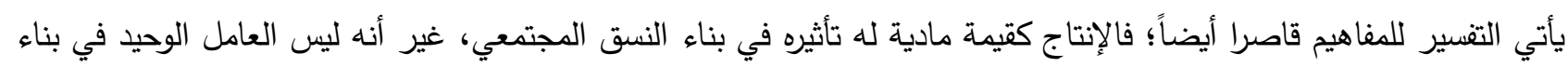

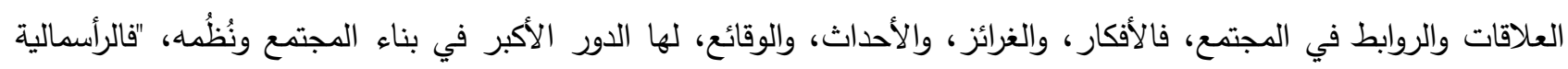

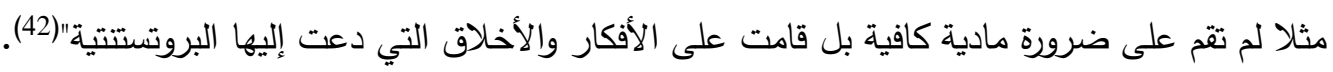

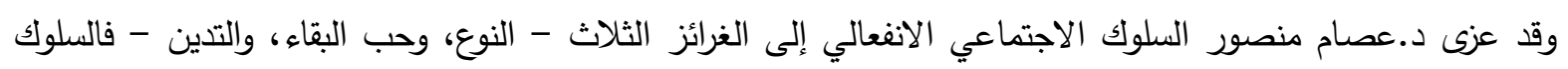

الاجتماعي الانفعالي مثل القتال، والهرب، والتملك، والحقد، والحسد والإيثار والأثرة...الخ ما هي إلا مظاهر للغرائز السالفة (43).

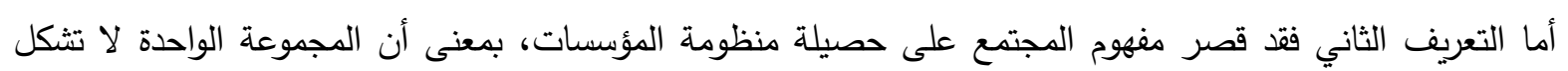
مجتمعاً وإن ربطت بينها علاقات دائمة ومصالح مشتركة، بل وكأنه يعرف الدولة ونظامها لا المجتمع.

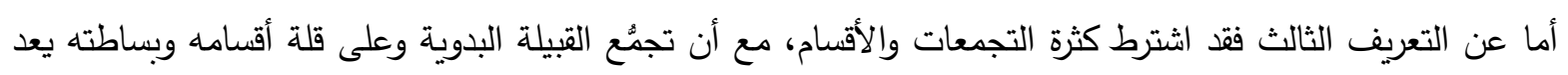
مجتمعاً بصرف النظر عن حجمه مقارنة بالمجتمع الحضري، وقد ذكر شتى وجوه ضبط السلوك الإنساني وأضاف إليها الحريات.

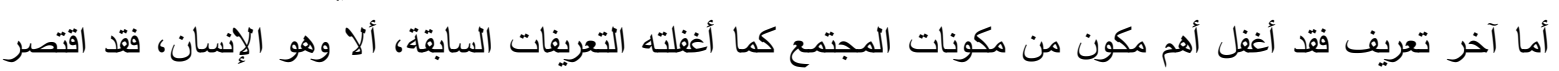

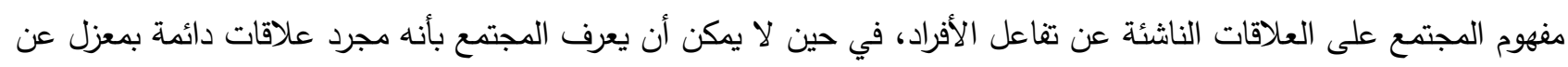

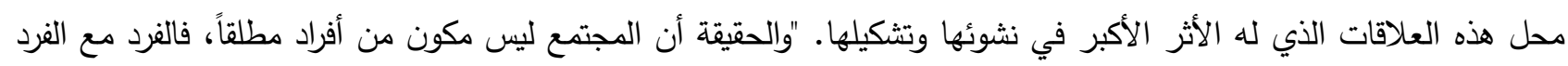

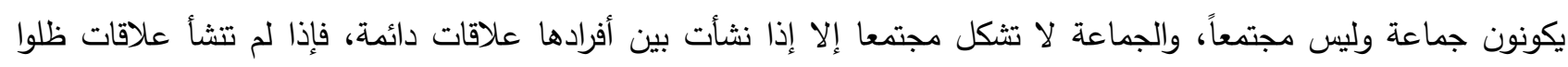

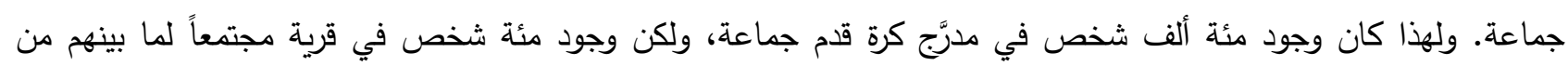

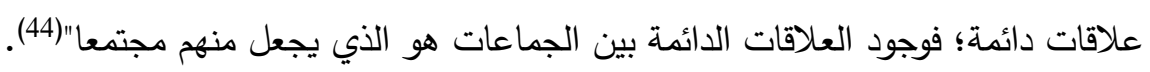

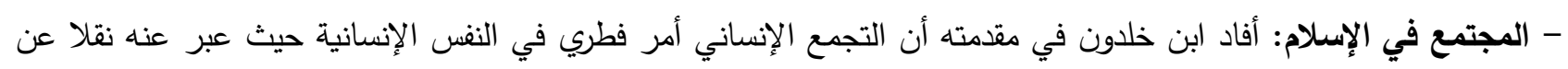

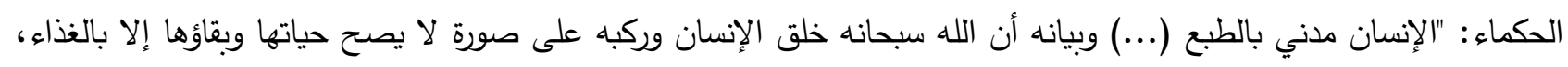

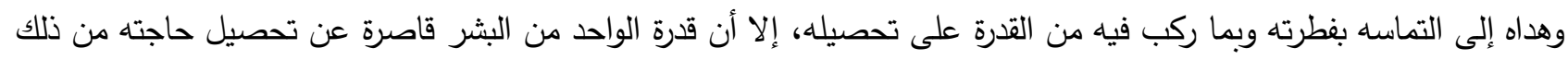

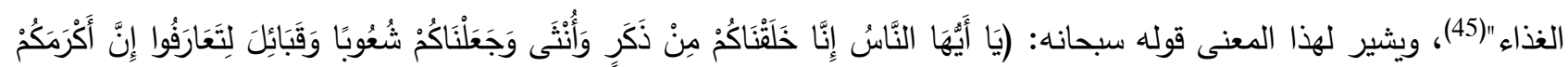

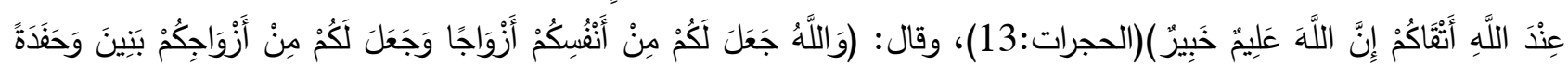

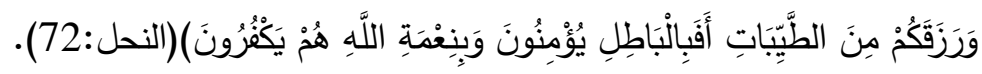

40- النبوي. مدخل إلى علم الاجتماع (ص87).

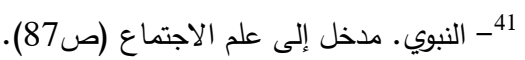

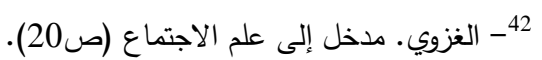

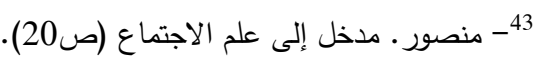

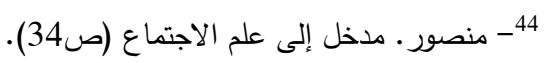

45- ابن خلدون. المقدمة (ص 41 ـ424). 
فهذه الآيات ترسم لنا الصورة الحقيقية الواضحة للمجتمع الإنساني؛ فقد بينت لنا نواة المجتمع الإنساني القائم على الزوجية المتمثلة بالأسرة، ثم الشعوب والقبائل التي تتألف من مجموع الأسر، وعبَّرت عن نشوء العلاقات الدائمة بالتعارف، وأن التهان

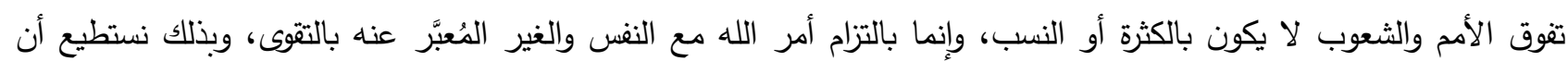

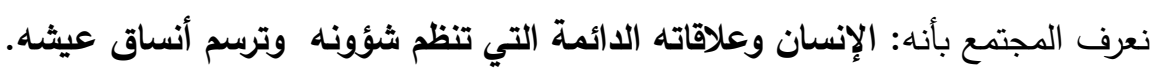
وبعد تحديد معنى المجتمع، لا بد من التعرف على ركنيه أكثر ، وعلى طبيعته، ليتسنى لنا للمس وآلية التغير فيه.

المسألة الثانية: أركان المجتمع وطبيعته.

1. الإنسان: وهو "الكائن الحي المخلوق لله تعالى، المتميز بالعقل والإرادة والاستخلاف في الأرض، والتكليف بالأيمان،

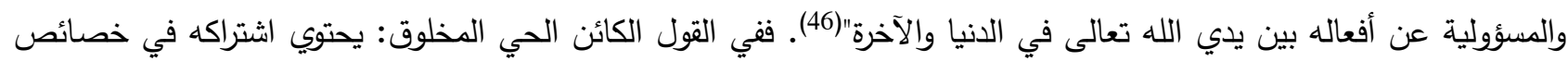
المخلوقات من حياة وموت ونمو وتبدل حال وتكونه من مواد الكون وعناصره، واشتراكه مع الحيوان في الحاجات والغرائز التي ما فا لئي

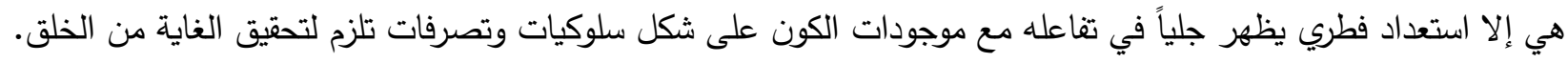

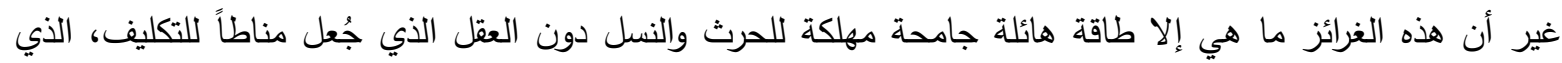
يحتوي التصورات، والمعلومات، والمعايير الصحيحة المستقاة من الوحي عن الكون والإنسان والحياة بمقتضى الإيمان والتكليف؛ لتحقيق الغاية من الوجود في عمار الأرض وسياستها بأمر الله وهديه؛ ليكون الإنسان هو خير البرية أو شرها تبعاً لإرادته وقصدها. 2.العلاقات الدائمة: ويقصد بها تلك العلاقات التي تأخذ طابع الديمومة، كعلاقة الأم بابنها، وعلاقة الزوج بزوجته، وعلاقلة الإنة الموظف بمجال الدولة ...الخ(47)، وهي الناشئة عن تفاعل الغرائز والحاجات مع موجودات الكون، لتثكل هذه التفاعلات في العقل

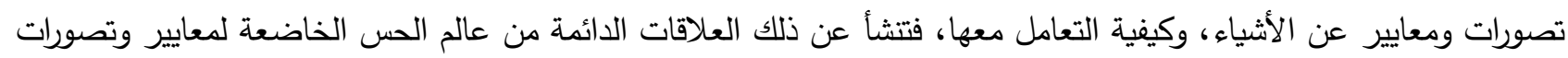

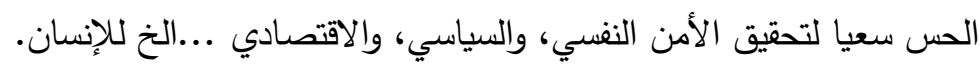
ولذلك وجد الوحي؛ لتزويد العقل البشري بالتصورات، والحقائق، والمعايير الصحيحة للأشياء؛ لتتحقق الغاية من الخلق

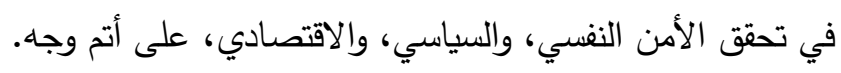

ثانياً: طبيعة المجتمع.

يفسر علماء الاجتماع نشوء المتمع البشري بتفسيرات عدة، أولها تفسير ابن خلدون الذي أفاد في مقدمته أن سبب نشوء

المجتمع الإنساني يعود لفطرته في عجزه عن إثباع حاجاته من الأمن والغذاء بمفرده، بوصفها قوام حياته (48).

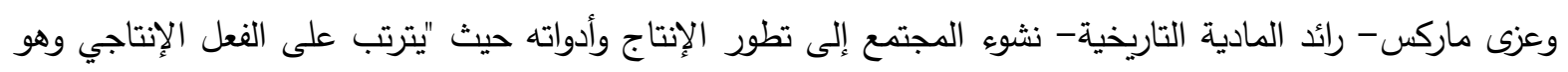

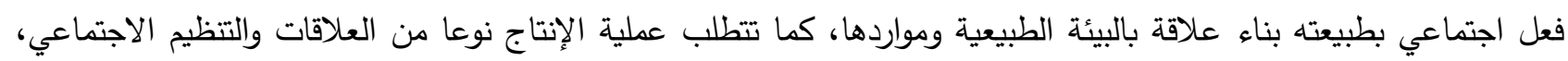
وتفترض عملية الإنتاج في علاقة الإنسان بالبيئة تحديد وجود موارد وتجهيزات وأدوات تثكل في مجموعها معنى مفهوم (وسائل

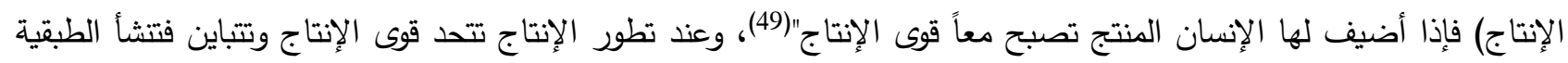
والصراع الطبقي.

46 سمارة. مفاهيم أساسية في العقيدة الإسلامية (ص 88).

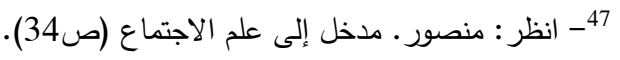

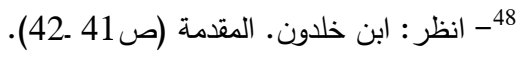

49- عثمان. مقدمة في علم الاجتماع (348).

99 IUG Journal of Islamic Studies (Islamic University of Gaza) / CC BY 4.0 
ويرى ماكس فيير أن سبب نشوء المجتمع وتغيره هو التحول والتغير الذي يحصل للأفكار والقيم، ودلل على ذلك بما

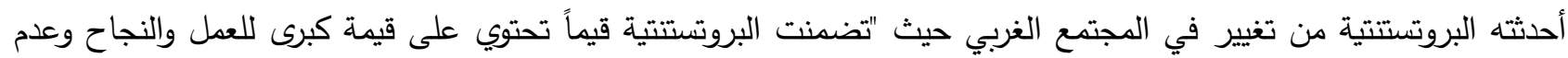

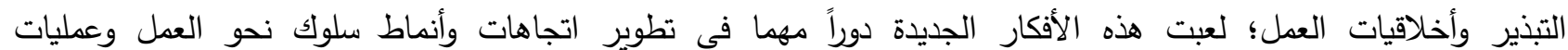
الإنتاج"(50). (150) أما طبيعة المجتمع في الإسلام فكل ما ذكر من عجز الإنسان عن إثباع حاجاته، ومن تطور الإنتاج وقواه، ومن تغير

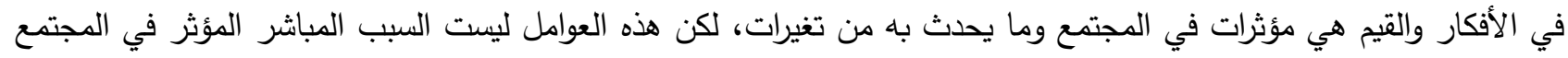
وعلاقاته؛ فيجب علينا أن لا نغفل الدور الأساسي للإنسان على هذه الأرض، وهو دور الخلافة الذي يقتضي تدبير شؤون حياته والتفاعل مع موجودات الكون وفق أمر الله تعالى. وقد اقتضت إرادته سبحانه وتعالى أن يكون مقتضى هذا التكليف العقل والإرادة التي يكونها الوحي، غير أن هذا العقل ما هو إلا حصيلة أفكار، وتصورات صالحة للحكم على الأشياء وإعطائها أوصافاً تحدد حقائقها، ووظائفها، وطريقة التعامل معها، وهذه الأفكار والتصورات إما أن يحصلها الإنسان من الوحي الإلهي الواصل إليه بطريق النبوة، فيهتدي به إلى التصورات والى والأفكار

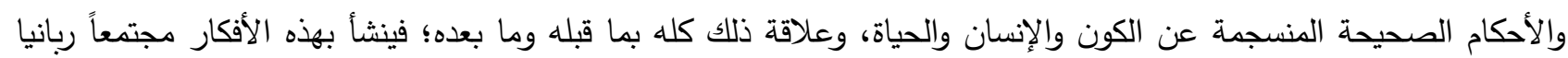

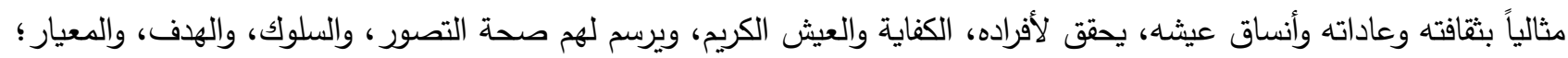

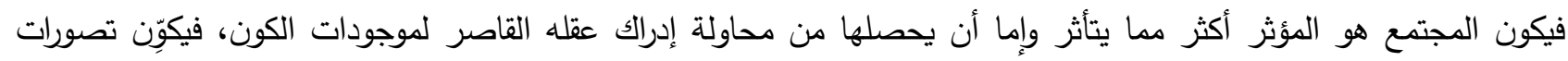

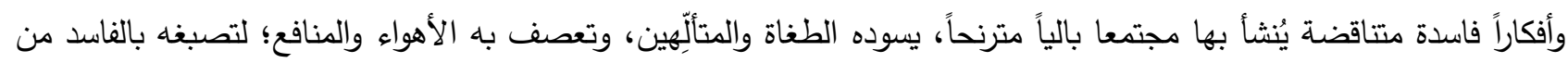
التصور ، والسلوك، والهدف، والمعيار؛ ليكون متأثراً بتعدد الأهواء والرغبات المادية المتقلبة وأربابها، فيكون متأثراً أكثر منه مؤثراً

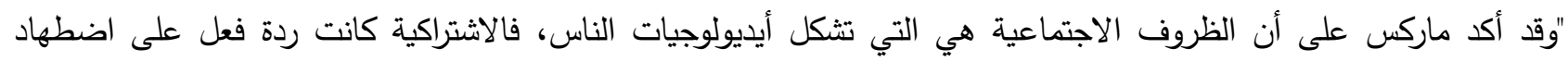
الرأسمالية"(51).

ويوضح ذلك أيضا ما حدث في أوروبا من تكوين تصورهم عن الكون والإنسان والحياة كردة فعل ضد الكنيسة وممارساتها(52)؛ فنشأت الإيديولوجية العلمانية، التي جعلت من العقل البشري آلهة، وهمِّشت دور الإله في واقع الحياة.

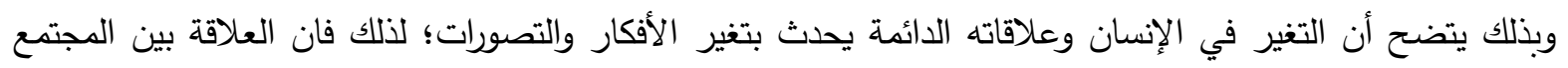

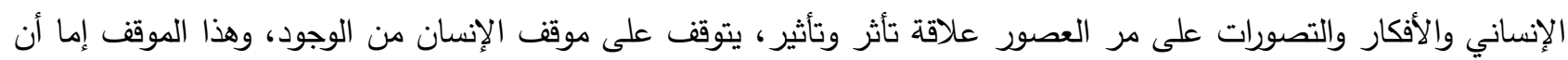

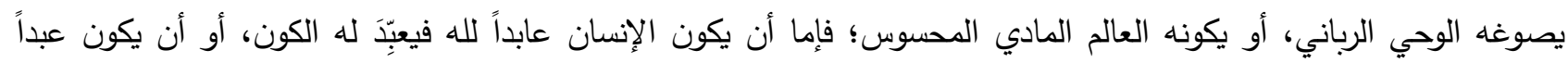
للكون وآلهته المزعومة.

ولا أدل على ذلك من مجيء الأنبياء عليهم الصلاة والسلام على مر الزمان؛ ليصححوا للمجتمعات البشرية التصور والسلوك، وتغير هذه المجتمات بتغيير تصوراتها، ثم النكوصِ إلى حالها بمجرد اندثار التصور الصحيح حتى بُعث النبي محمد

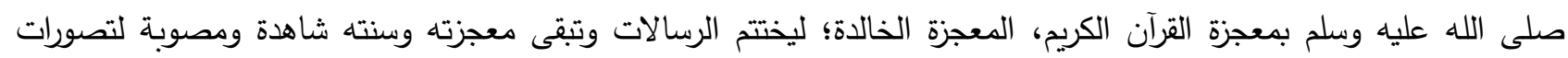
البشر وسلوكياتهم على مر العصور، وكما قال عمر رضي الله عنه: نحن قوم أعزنا الله بالإسلام فمتى ابتغينا غيره أذلنا اللهات(53).

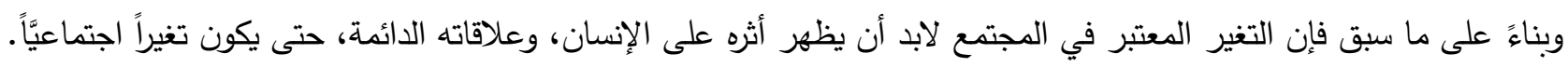
المطلب الثالث: تأثير الإعلام في الثقافة الإسلامية.

50- عثمان. مقدمة في علم الاجتماع (ص1351). 51 51 الغزوي. مخل إلى علم الاجتماع (ص فل 292).

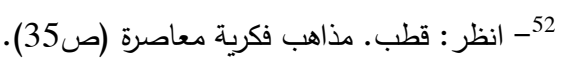

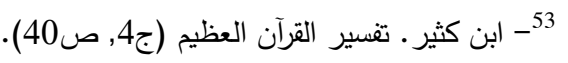


المسالة الأولى: مفهوم الثقافة وأنواعها.

أولاً: مفهوم الثقافة لغة واصطلاحاً.

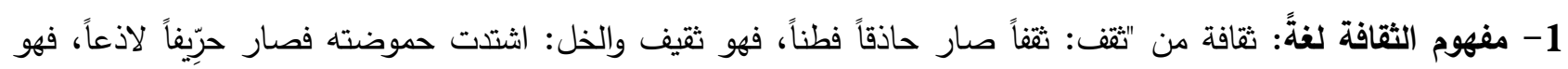

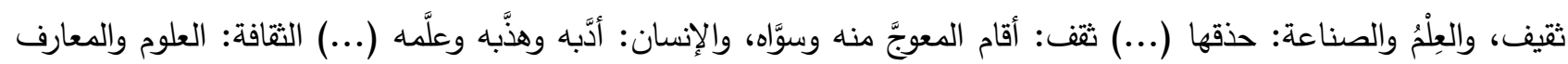

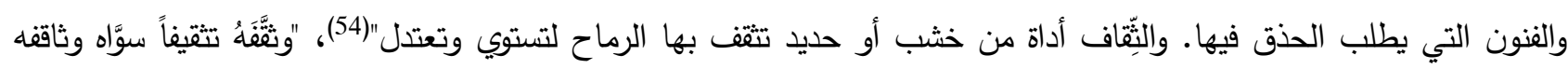

فثتقه كنصره غالبه فغلبه في الحذق" (55).

ويتضح من خلال ما ذكر أن لفظة الثقافة مستمدة من الجذر اللغوي تَفِفَت الذي يدل على الفِطنة، والحذاقة، وتقييم المعوج، وتتعدى هذه الألفاظ للإنسان؛ لتعبر عن الإنسان المُقوَّم بالأدب والعِلم والتهذيب.

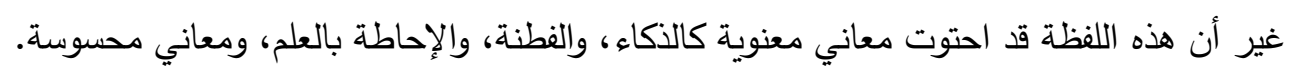

2- مفهوم الثقافة اصطلاحاً: عرِّفت الثقافة تعريفات عديدة منها:

- "جميع أنواع السلوك المتعلم والمتوقع في مجتمع؛ فيثمل المعنى العمران والأدوات ووسائل علاجها، كما يتضمن النظم والمعتقدات وأنواع المعرفة والفنون والآداب والقيم والمعايير والتقاليد والعادات والأعراف، أي كل ما أنتجه الإنسان أو ما تبناه ضمن حياته الاجتماعية"(56).

- "هي مجموع ما يحصل عليه الفرد من مجتمعه، من المعتقدات والتقاليد تكونت على مدى التاريخ"(57). - "جملة العلوم والمعارف والفنون التي يطلب الحذق فيها"(58).

ففي التعريف الأول، يتركز معنى الثقافة في السلوك المتعلم، ويذكر العمران والأدوات والوسائل دون التركيز على سمة

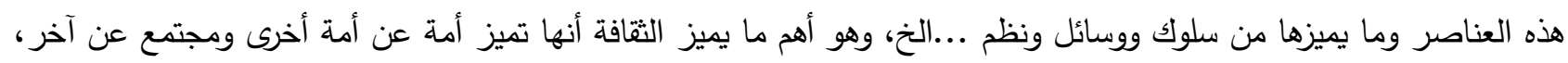
كما ظهر إدخال العلم التجريبي ضمن الثقافة في قوله أنواع المعرفة.

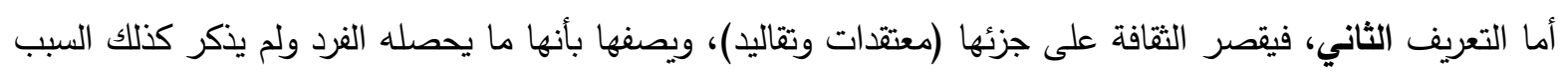
الذي يجعلها علامة فارقة لأمة على أخرى أو لمجتمع على آخر . والتعريف الثالث، عام يقتصر الثقافة على العلوم والمعارف دون التركيز أو مجرد الذّكِكر للمعتقدات والمفاهيم والأفكار المؤثّرة في السلوك، فهو يحتاج لضبط حدوده وإبراز معالمه. والظاهر أن العلماء لم يتفقوا على تعريفٍ واضحٍ للثقافة؛ لتكون لفظة دالة عليه في جميع المواقف والمحافل العلمية

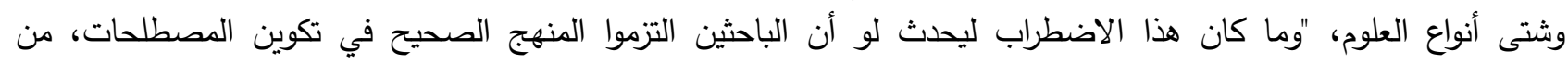

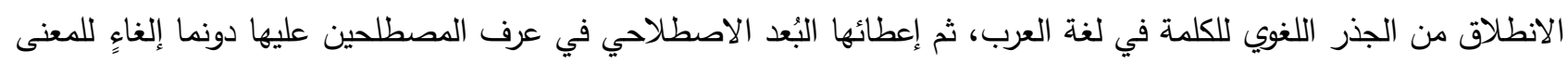

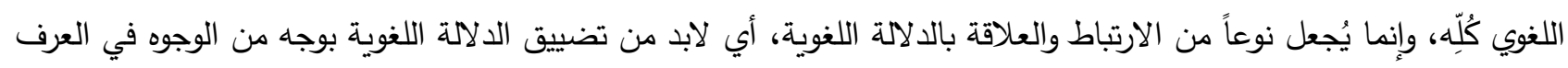
الاصطلاحي كي تصبح الدلالة الاصطلاحية للكلمة حقيقة عرفية لدى المصطلحين عليها (...) ثم لابد أن يكون المصطلح

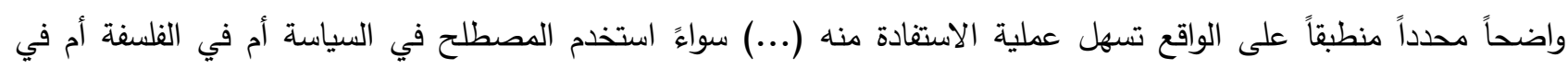
الاجتماع"(59).

$$
\begin{aligned}
& \text { 54 - مصطفى. الهعجم الوسيط (ص 98). }
\end{aligned}
$$

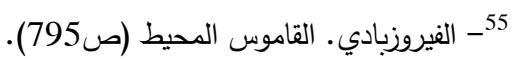

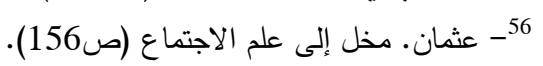

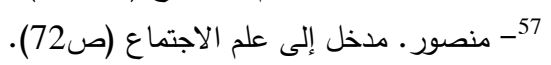

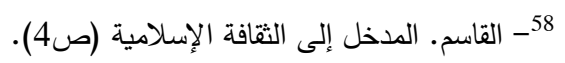

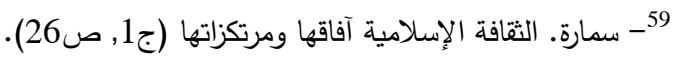

101 IUG Journal of Islamic Studies (Islamic University of Gaza) / CC BY 4.0 
ولعلَّ أنسب تعريف للثقافة بمعناها العام ما ذكره د. إحسان بأنها: "نمط معرفي مكتسب مرتبط بالإنسان في تكوين

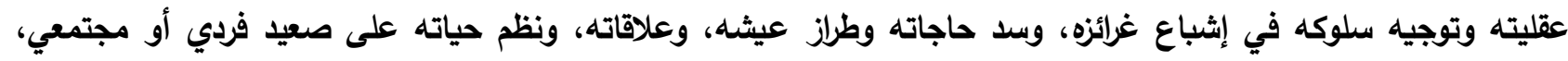

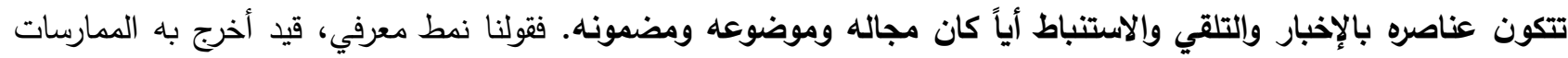
العملية والوسائل والأساليب المادية والمعارف الفطرية من الحركات الإرادية الصادرة عن الإنسان بفعل الطاقة الحيوية وما يصاحبها من مشاعر وأحاسيس فطرية كالتعبير عن الجوع والألم والحرمان ونحو ذلك. وقولنا يرتبط بالإنسان في تكوين عقليته وتوجيه سلوكه؛ قيد نخرج به المعارف العلمية التجريبية، وقولنا في إثباع غرائزه وحاجاته... قيود تحصر مجالات المعرفة الثقافية (...) وقولنا تتكون عناصرها بالإخبار والتلقي والاستتباط، قيد يبين كيفية تكون المعارف الثقافية ليميزها بذلك عن غيرها من

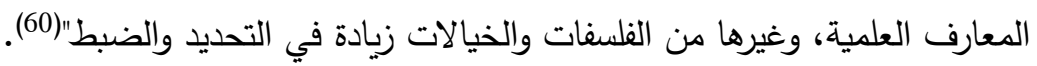

وعلى ذلك تكون الثقافة الإسلامية هي: "تمط معرفي تحتمه العقيدة الإسلامية، وتبعث على بحثه ووجوده، يتعلق بالإنسان في تكوين عقليته وميوله، وفي بناء علاقاته ونظمه، وتحديد أنماط سلوكه وطراز عيشه على صعيد فردي ومجتمعي ودولة وأمة" (61). ففي هذا التعريف تتحصر الثقافة وتتحدد بأنها النمط المعرفي المؤثر في الإنسان وعقليته وميوله، والموجّة له في سلوكه وعلاقاته ونظم عيشه، أياً كان مصدر اكتساب هذا النمط، سواءً كان مصدره الوحي الرباني المتمثل بالعقيدة الإسلامية، أم كان

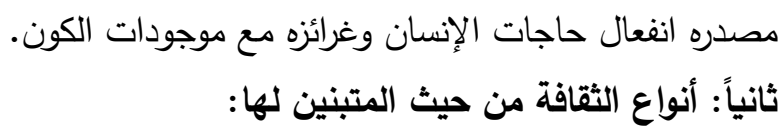
1. الثقافة الخاصة: وهي عبارة عن العناصر الثقافية التي يثترك فيها مجموعة معينة من أفراد المجتمع اتسموا بفكرٍ خاص قد يناقض الفكر العام وقد يتفرد عنه بأنماط سلوكية أو عادات أو تقاليد أو قيم تختلف عما هو مشترك بين جميع أفراد المجتمع،

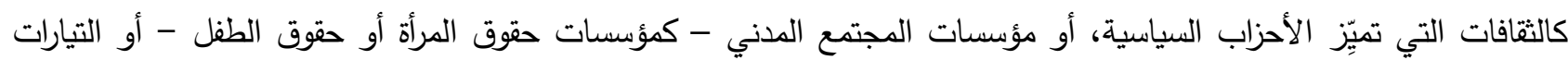
والطوائف الدينية التي تتميز بأفكار وسلوكيات ونشاطات خاصة تتميز عن فكر المجتمع وسلوكه، إما تركيزاً لبعض الفكر السائد، أو مخالفةً له، فالمجتمعات ذات الرقعة الجغرافية الكبيرة والتركيب السكاني المعقد تكثر فيها الخصوصيات الثقافية الثية أو الثقافات الفرعية والخاصة.

إلا أن هذا النوع من الثقافة يبقى ذائبا في العموميات، أو ما يسمى بالثقافة العامة وضعيف التأثير في ظلها، لكونه

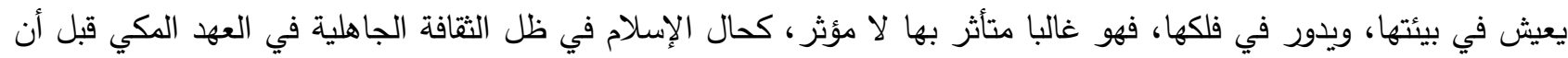
يصبح ثقافة سائدة كما أصبح في العهد المدني. 2. الثقافة العامة: أو ما يطلق عليه بالعموميات، أو الرأي العام، أو الثقافة السائدة، وهي التصورات والأفكار المشتركة لدى جميع

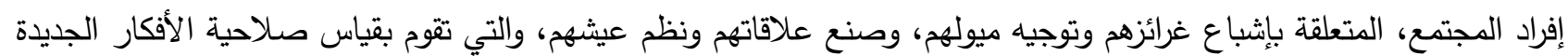
من عدمها، فهذا النوع من الثقافة ما هو إلا الدرع المنيع لهوية المجتمعات والحامي لخصوصياتها وملامحها، وهو الميزان الذي وني يزان فيه كل ما هو جديد من أفكار ومعتقدات، وقيم وميول، وعلاقات ونظم، والمحدد للمرغوب والمكروه، والحسن والقبيح، والنافع

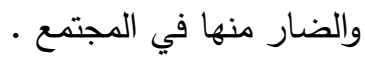
ويجدر هُنا مناقثة مفهوم الرأي العام؛ "رأي الأغلبية، وهو نموذج معين من الفكر والقول يعم ويسود على النماذج

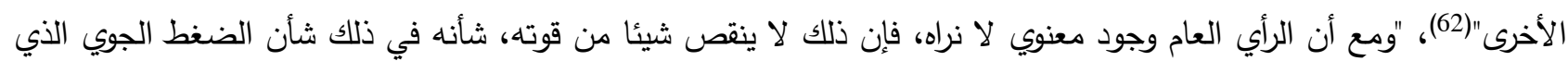
لا نراه ولكنه موجود"(63)، وقد عرف الري علماء النفس والاجتماع والسياسة الرأي العام بتعريفات منها: 
أ- "اعتتاق الجماعات لأفكار نظرية تأملية يقصد تغيير وتطوير المؤسسات السائدة"(64). ب- "مجموع اتجاهات الناس الأعضاء في نفس المجموعة الاجتماعية نحو مسالة من المسائل التي تقابلهم"(65).

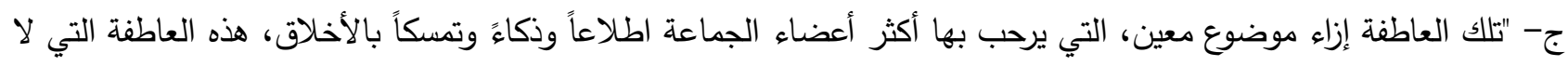
تفتأ وتعتنق تدريجياً من جانب جميع الأشخاص تقريباً التي تتكون منهم جماعة ذات مشاعر سوية تعيش في دولة متمدنة متحضرة" (66). فأول تعريف أغفل الجانب المادي السلوكي المعبر عن الرأي العام، وابتعد الثاني عن واقع الرأي العام المتمثل باتجاه واحد للمجموع، أما الثالث فقد أطلق عليه لفظ العاطفة وقرن بينها وبين أكثر أعضاء الجماعة ذكاءً في حين أن حقيقته لها حظاً

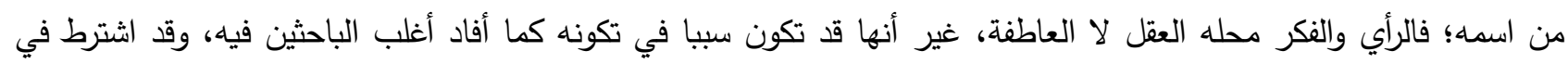
أعضاء الرأي العام المثالية وهي ليست شرطا في تكونه، فقد يكون الرأي العام فاسداً أو صالحاً تبعاً لمصدره وبذلك يمكن تعريفه

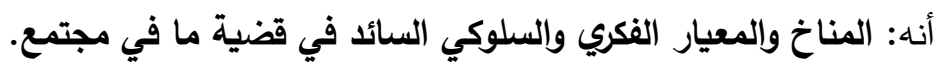

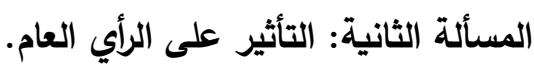

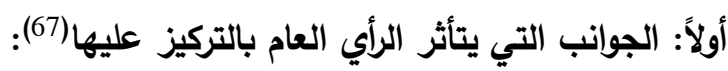

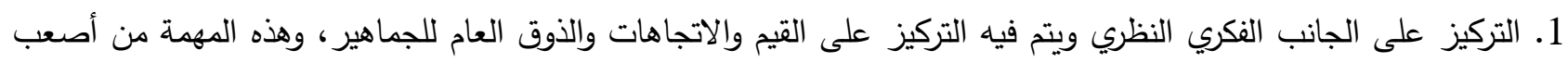
المهام لاى الإعلاميين حيث إن أصعب تغيير هو تغيير المعايير والأفكار والقيم، فهي الحصن المنيع للأمم من الغزو الفكري، حيث إن قيمة المجتمعات بما تعتتق من أفكار وقيم، فان ضُربت وضاعت ضلت طريقها وأصبحت كالغراب الذي نسي مشيته ولم

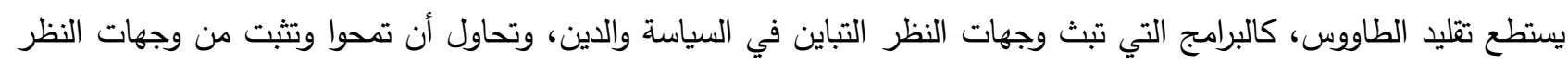

ما تثاء.

2. التأثير على مدى المعرفة والاستيعاب، لأن المعرفة تتأثر بالتعرض المتكرر للمعلومات وكذلك قد يتأثر الذهن بفكرة أو معلومة ما في الوسيلة الإعلامية تستدعي الوعي والانتباه عند المتلقين، وهذه المعلومة يرتبط تأثيرها بمقدار ما لها مساس وأهمية بالمتلقي ومدى تفسيره للمعلومة ومدى حاجته لها، كالبرامج الهابطة التي تفتقر لرقي الذوق، وتعنى بسفاف الأنياه الأمور وتوافهها، فقد يدرك

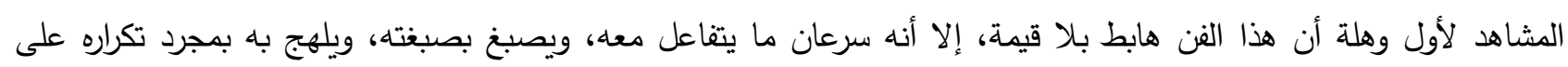

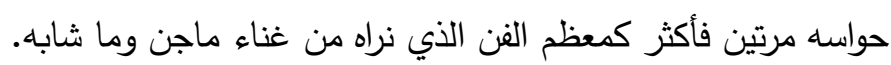
3. ترتيب الأولويات في المجتمع، ويكون من خلال إعطاء قيم للأشياء، وترتيب الأولويات، وإضفاء الأهمية وسلبها عن الحوادث

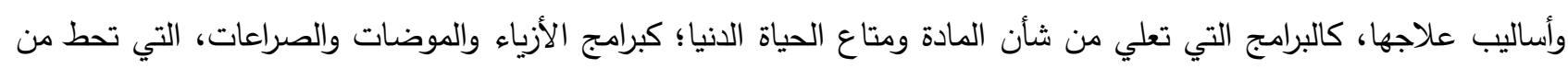

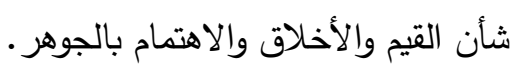
4. التركيز على التغيير في الجانب السلوكي، ونمط العيش، واستغزاز الغرائز ، وهذا النوع من التغيير يستغرق وقتا لحدوثه، وهو

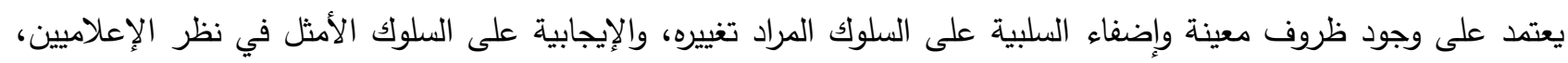

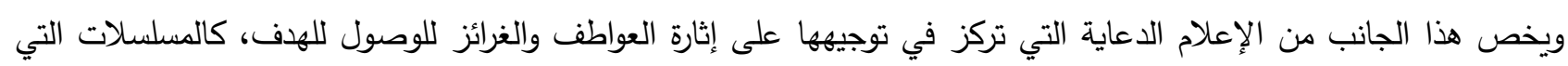
تعرض قصص الحب الثريفة بزعمهم؛ فتضفي على ما بها من سلوكيات صفة الثرعية بزعم أن الدين والإيمان بالقلب لا علاقة له بالسلوك الإنساني.

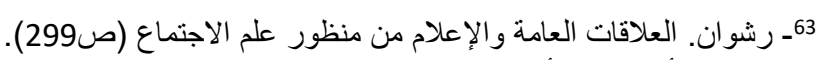

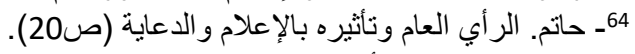

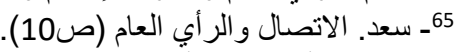

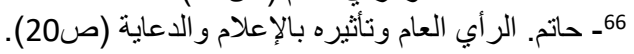

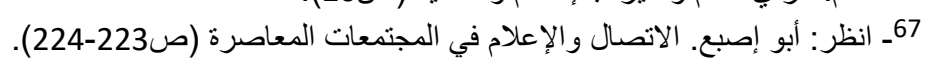
103 IUG Journal of Islamic Studies (Islamic University of Gaza) / CC BY 4.0 
ثانياً: عوامل تأثير وسائل الإعلام على الرأي العام (68): 1. يختلف تأثير الإعلام على الرأي العام بتتوع وسيلة الاتصال، فكل وسيلة إعلامية لا بد أن تتميز عن غيرها من الوسائل في

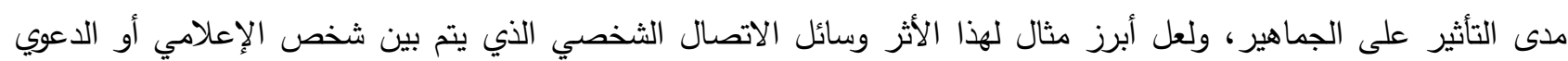

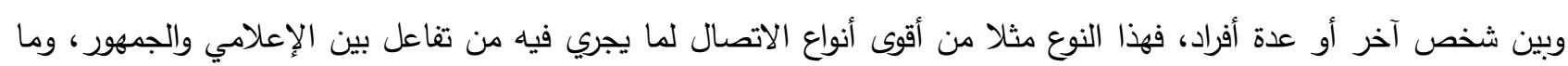

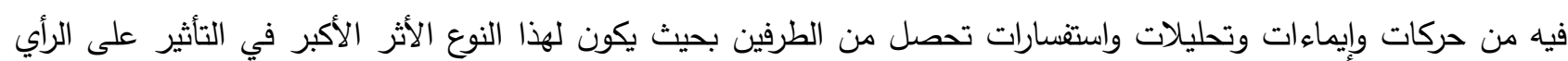

2. ويختلف كذلك أثر الإعلام باختلاف القضايا والمضامين التي يحويها، فكلما كانت القضايا أكثر مساساً لحاجات واهتمامات

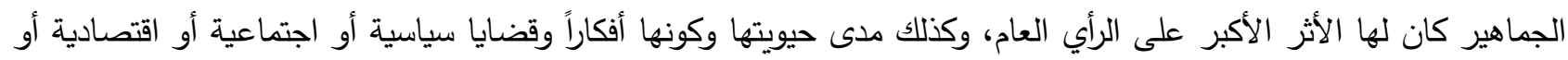

3. كما يختلف باختلاف شرائح الناس الذين يتعرضون للإعلام، فالثريحة المثقفة أقل تأثراً بوسائل الإعلام، والثريحة الثعبية أو العوام أكثر تأثراً بها، أما شريحة السياسيين فهم المسيطرون على وسائل الإعلام وما فيها أي أنهم المتلاعبون بالعقول. 4. وكذلك الظروف المحيطة بالمجتمع التي قد تجبر الإعلام على الاتجاه وجهة معينة حتى يستطيع التأثير ، فمثلا لا قيمة لإعلام

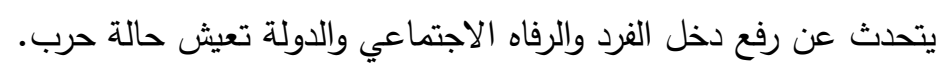
وتتم عملية التأثير على مستوى الفرد من خلال إضافة المعلومة الجديدة إلى إطاره المعرفي وربما يجعلها معياراً، أو يقبل

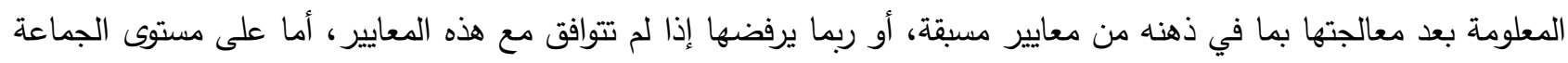

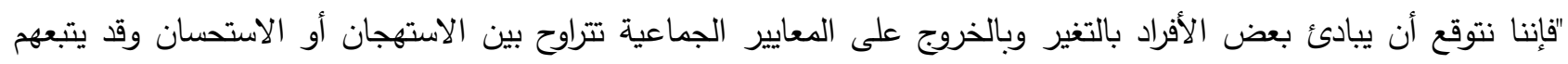

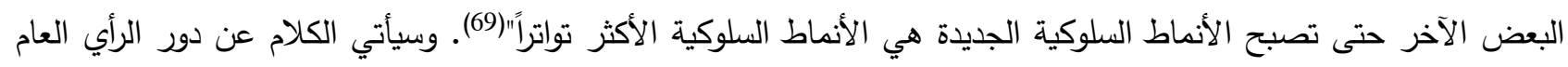

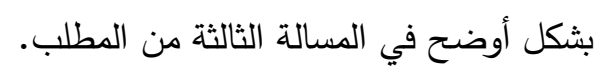
المسألة الثالثة: أثر الإعلام في الثقافة الإسلامية. إن أهم ما يؤثر في عملية تأثير الإعلام في الثقافة هو طبيعة الثقافة نفسها، ومدى الإملامية وعي الإنسان على ثقافته، فإن كانت

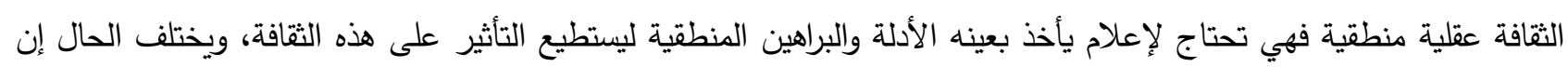
كانت الثقافة عاطفية. ويتأثر مستوى التأثير كذلك في مدى وعي الإنسان على ثقافته ومعرفته بها "فثثلاً استخدمت وبشكل واسع وشامل رسائل

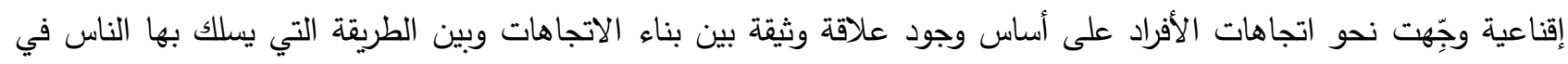

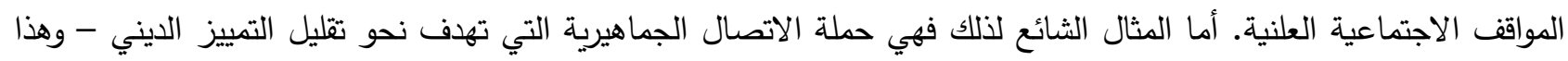

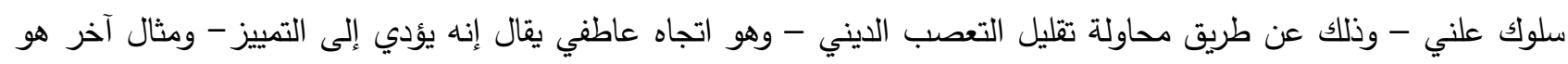
تشجيع شراء الأدوية الأصلية- سلوك علني - وذلك بغرس الخوف من سوء الصحة أو استمرار المعاناة - حالة أو عملية نفسية-

وقد جرى استغلال الجماهير وإثغالهم في حملات إعلامية متتابعة حول جنون البقر ، وأنغلونزا الطيور والخنازير ، ومن ثم

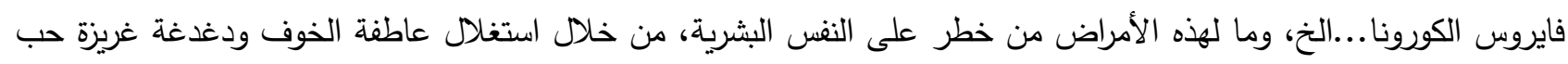
البقاء؛ لينشأ رأي عام في ضرورة أخذ الأساليب الوقائية اللازمة من هذا المرض، من نظافة وتطعيم وعلاج؛ حتى يسيطر هذا

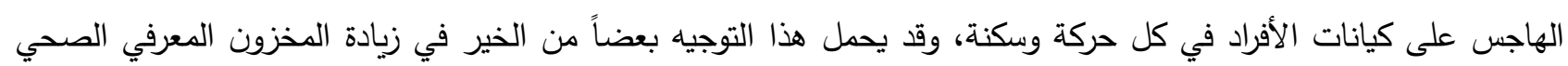


ومن ثم ينعكس على السلوك الوقائي لدى الجماهير ، إلا أن الثيء يحكم عليه بأصله وأساس وضعه، إذ لا يمكن إغفال دور كبرى شركات الأدوية في العالم الرأسمالي في هذه الحملة الإعلامية التي تجاهلت طاحونة القتل والتدمير في العالم التي تدير رحاها

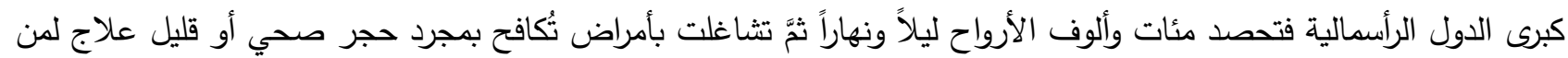

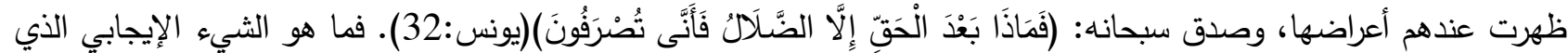
ستقدمه الثقافة الغربية للثقافة الإسلامية..؟! ويجدر الإشارة إلى أن الإعلام لا يستطيع التأثير في الثقافة بمعزل عن دراسة الثقافة ذاتها، والأحداث التي تكتنفها، فمن

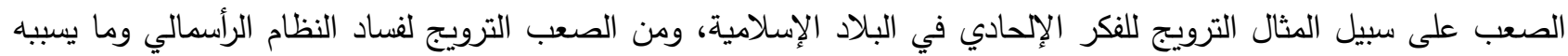

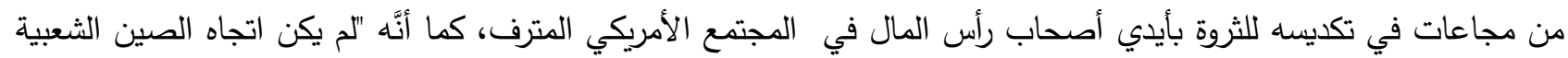
إلى الثيوعية نتيجة الدعاية أو التعاليم الماركسية وحدها ولكن حكم تثانج كاوتشيك الفاسد" (71). أولاً: أثر التواصل الإعلامي الثخصي: فقد ظهر مثلاً في دعوة أحمد القادياني في الهند بدافع من الإنجليز "أخذ القادياني يدَّعي

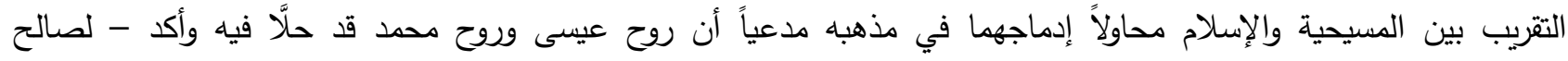

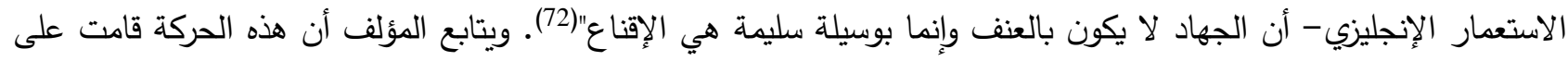
أنقاض هدم الخلافة العثمانية؛ لسد الفراغ الذي حصل عند المسلمين من جراء ذلك ويتابع "إن القاديانيين كانوا يرون أن وطنهم الروحي الذي يحجُون إليه كائن في قاديان وليس في مكة المكرمة"(73).

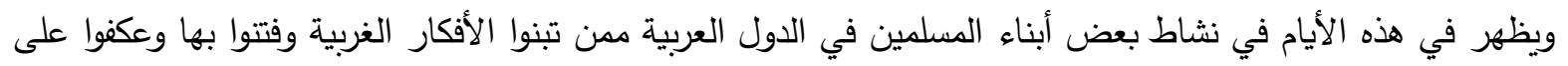
نشرها والدعوة لها من خلال منظمات ومؤتمرات وتجمعات مشبوهة بحجة حقوق الإنسان وحقوق المرأة؛ ليدعوا لتحرر المرأة، لهاء وحقوق المثليين، وضرورة تغيير قوانين الأحول الثخصية والميراث وغيرها(74).

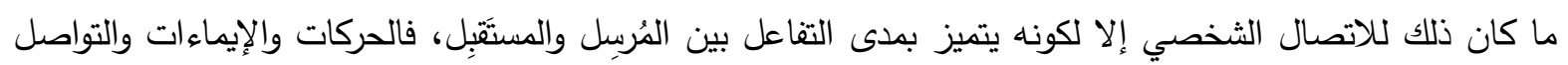

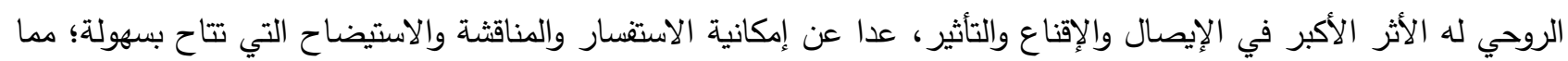
يجعل الأثر الأكبر في إيصال الفكرة وتغيير الرأي. وقد ضعف استخدام هذا الاتصال عند المخلصين من المسلمين لما يواجهون من ضغوطات من حكامهم، وهيمنة النظم التعليمية العلمانية والفراغ الفكري والثقافي؛ بسبب الجهل الذي نتج عن ضعف الدولة العثمانية وانحسار دورها بالاهتمام بالعلم والعلماء في أواخر عهدها وتعرض الأمة لهجمات الغزو الفكري وحملات التغريب؛ مما أدى إلى فقدان المسلمين لحصنهم

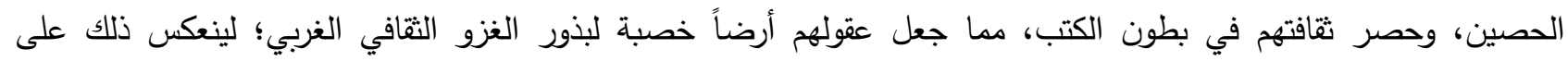

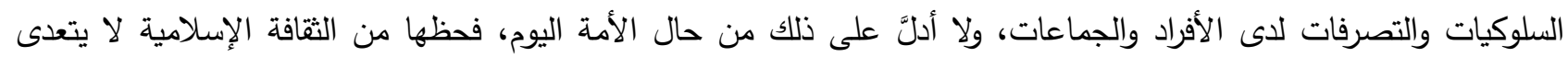
ركعتين أو أربع في المسجد دون سائر نشاطات الحياة؛ حتى غدا تديننا بالإسلام كما حذرنا رسول الله صلى الله عليه وسلم، وكما

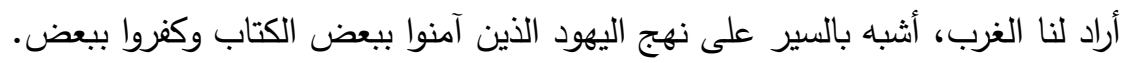
ثانياً: أثر الاتصال المرئي والمسموع والمقروء: فيبرز من خلال اتساع جماهيره على اختلاف شرائحهم بين مثقف وأمي وسياسي...الخ، وهو بذلك على العكس من الاتصال الثخصي الذي يستهدف شرائح معينة ومحدودة، فالاتصال الجمعي في

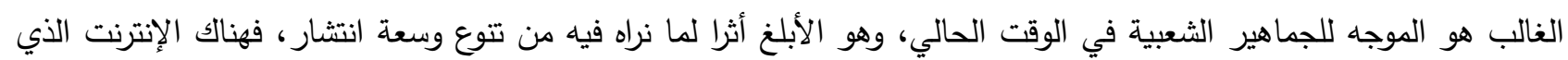

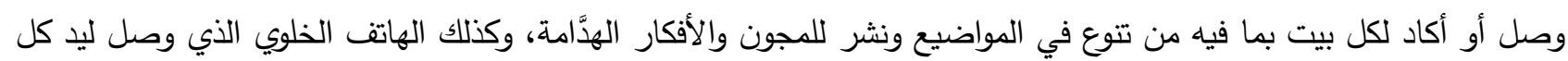

71- رشوان. العلاقات العامة و الإعلام من منظور علم الاجتماع (ص238).

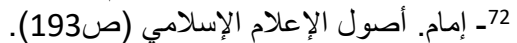

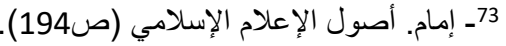
74 - 7مارة. مكالمة هاتفية (2020/4/25). 
شاب وما له من أثر في تتاقل الصور والأفلام الخليعة التي تثغل الثباب عن الحق وتدخلهم في أتون هوس الثهوات والملذات، بعيدا عن العفة والنهضة والرقي الفكري.

ويظهر كذلك أثر الاتصال الجمعي فيما صارت إليه قيم المجتمع الإسلامي، فغدا المعروف منكراً والمنكر معروفاً،

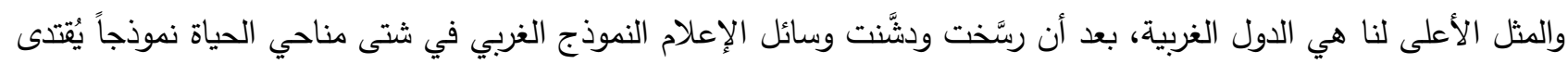

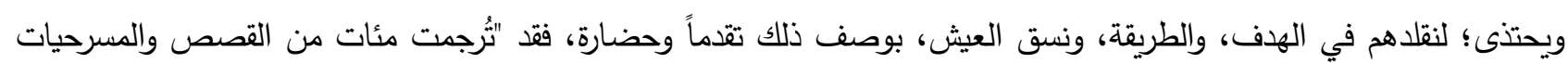
والكتب التي تحمل الفكر الغربي - العلماني - الجاحد للدين المناوئ له مع عناية خاصة بنشر أفكارٍ عن نظرية التطور الداروينية، فأما القصص والمسرحيات فقد كان الهدف من نشرها على نطاق واسع هو تحطيم التقاليد الإسلامية التي تمنع الاختلاط وتنفر من الفاحشة والتحلل الخلقي"(75). وأمسى حال كثيرٍ من العوام كالأنعام يساقون سوقها، هائمين لاهثين وراء بطونهم وفروجهم، وخواصنا على ثلاث طرات طرائق:

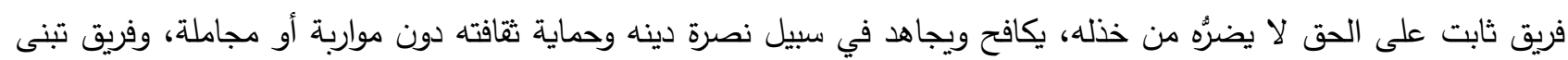

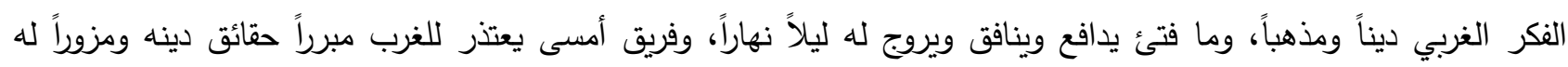

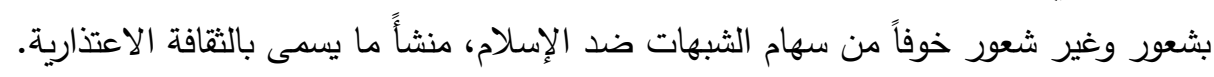
ثالثاً: التغيرات الجلية في العناصر الرئيسة للثقافة الإسلامية:

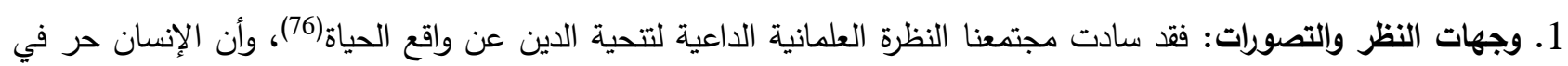
فعل ما يشاء؛ لأن الله خلق الكون وتتزَّه عن تصريفه وأوكل هذه المهمة للإنسان، وسخر الإعلام كل طاقاته لتعزيز هذه الأفكار، كأل

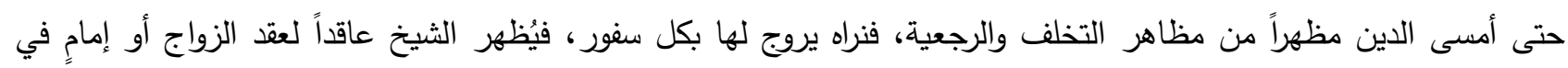

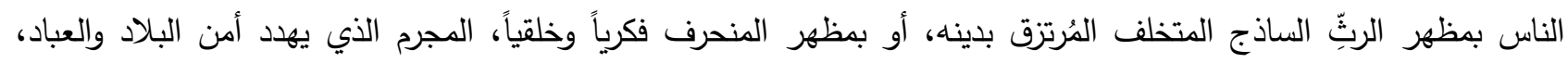
المتحجر في الفكر وضيق الأفق، المُكدِر لصفو حياته وحياة غيره، المعاني من الفقر والعوز والضغوط الاجتماعية التي ألجأته

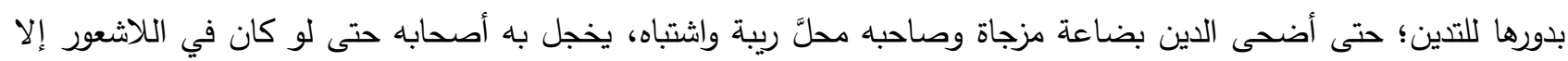

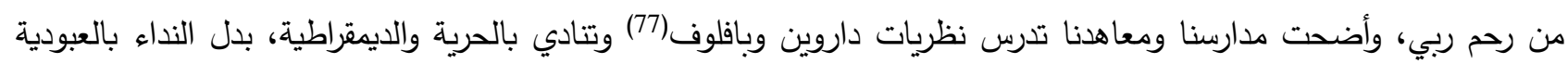
والحاكمية لله سبحانه، فيقول محمد قطب: أما الكتب التي تحمل الفكر العلماني فالهدف من ترجمتها واضح كذلك يقول أ. شاتيلييه في مقدمة كتابه الغارة على العالم الاسلامي: "ولا شك أن إرساليات التبشير من البروتستتنية وكاثوليكية، تعجز عن أن تزحزح العقيدة الإسلامية في قلوب منتحليها، ولا يتم لها ذلك إلا ببث الأفكار التي تتسرب من اللغات الأوروبية (...) وتمهد السبيل لتقدم إسلامي مادي. وتقضي إرسالية التبشير لبناتها من هدم الفكرة الدينية الإسلامية التي لم تحفظ كيانها وقوتها إلا بعزلتها لتابها وانفرادها"(78)، "وقد استطاعت اليهودية العالمية عن طريق ترويج أفكار داروين وتوسيع نطاقها أن تحطم ما كان قد بقي من عقائد

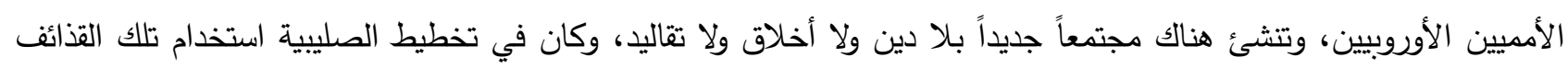

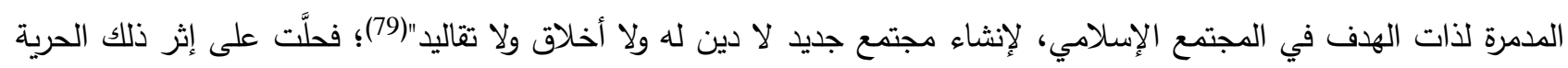

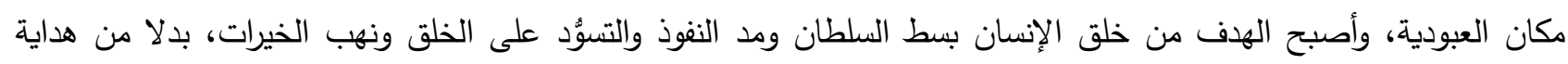

75- قطب. واقعنا المعاصر (ص 235). 76- انظر : إمام. أصول الإعلام الإسلامي (ص 199 192. 77- نظرية التطور لداروين, والارتباط الشرطي لبافلوف. 78- انظر : قطب. واقعنا المعاصر (ص 238-237). 79- قطب. واقعنا المعاصر (ص 237 237). 
الناس والرأفة بهح وإخراجهم من الظلمات إلى النور، وتعددت الولاءات للمال وللسلطان وللقوم وللعشيرة وللفرقة وللمنصب تبعا للهوى كلُ بحسب هواه.

2. القيم والقناعات: تبدَّلت القناعات فكان مفهوم السعادة ومصلحة البشر مرهوناً بالتزام أمر الله سبحانه والتباع هديه فأضحت في الرغبة والهوى والمصلحة المظنونة، فكل مشبع للحاجة، مرض للرغبة، محقق للمتعة فيه السعادة والصلاح، واعتلت القيمة

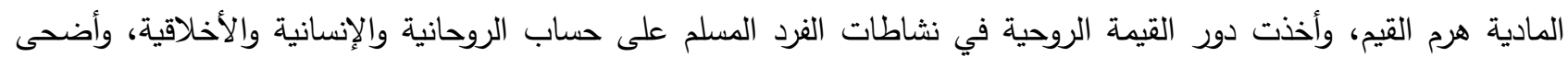
المال القيمة الحقيقية لكل شيء توزن به الرجال والأعمال، وسادت القيم الغربية في تقديس حرية الفرد وإرادته واحترام خياره مهما كان فاسداً، ومهما خالف الأعراف والأخلاق والدين، فما هي إلا قيود فرضها المجتمع الغاشم القاهر للفرد وحريته، "وقد كان الفن وته الذي يترجم هو الفن الذي تخلص تماماً من القيم الدينية، وراح يدعو إلى إقامة مجتمع طليق من تلك القيم، ودئ... مجتمع يهبط تدريجياً حتى يصبح مجتمعا حيوانيا في النهاية"(80). 3. النظم: فقد تحولت النظم من نظم إسلامية إلى نظم وضعية دكتاتورية تحكم بالحديد والنار رغم احتوائها على نزغ يسير من الأحكام الثرعية في الزوجية والميراث، فالثيء يعرف بأساسه وجُلّهِ، ففي مجال السياسة: حل النظام الجمهوري والنظام الديمقراطي مدَّعي الحرية الذي يركز على حاكمية الثعب وشرعية قرار الأغلبية(81)، وحق الثعب في تقرير مصيره وتتظيم شؤونه في الحياة في داخل الدولة وخارجها، انطلاقاً من الإيديولوجية العلمانية. وفي الاقتصاد ساد النظام الاشتراكي فترة من الزمان، ثم انحسر بفعل المد الرأسمالي الذي سادت أفكاره، "الأغنياء حصلوا

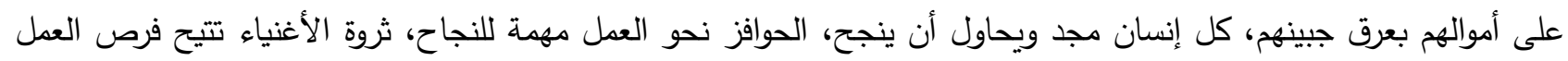
للفقراء (...) هذه تبريرات جزء من إيديولوجيا المجتمع الرأسمالي وإن كان هناك من يعارضها في هذه المجتمعات، ويستخدم

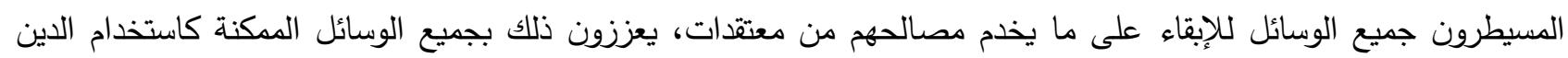

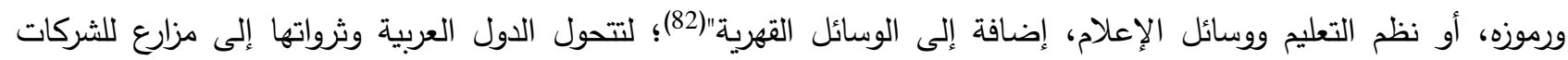

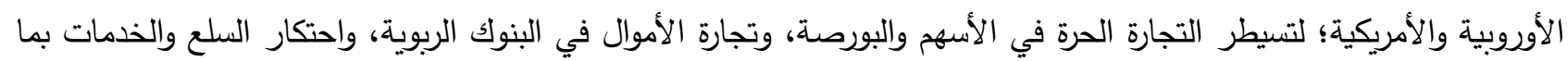
يسمى بحقوق الامتياز .

وفي الاجتماع ترى الثيوعية تقديس المجتمع وأنه ملهم الأفراد ومقومهم وقوام حياتهم، فليس للفرد الحقير الضعيف

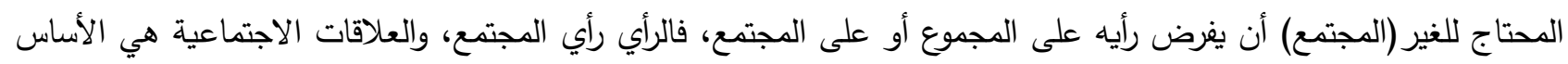

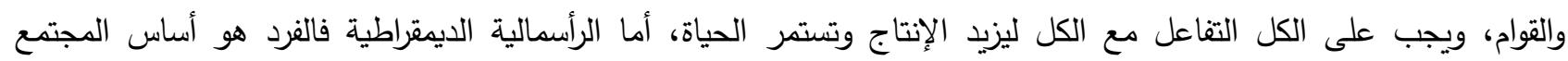

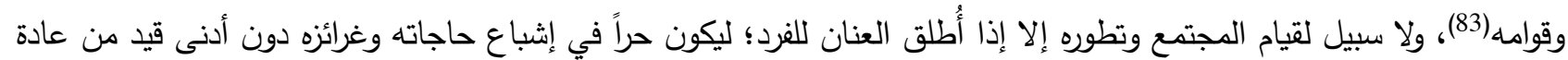
أو دين أو عرف اجتماعي؛ حتى تتفجر طاقاته في الإبداع والتطوير (84)، وليس للمجتمع الذي ما هو إلا مجموعة أفراد - بزعمهم-

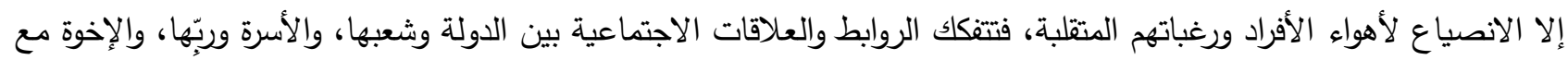
بعضهم، تبعاً لتعدد الرغبات والأهواء والأفكار والتتافس على الألى المصالح. فزال على إثر ذلك كله نظام الخلافة، ودُرست أحكام الملكية في الإسلام، وبدأ ينهار النظام الاجتماعي الإسلامي؛ بدعوات هدَّامة لتنظيم النسل وتحديده، وهدم الأسرة أخلاقياً؛ ليمسي ذلك كله جزءاً من التاريخ في طي النسيان لا رجوع إليه.

$$
\text { 80- قطب. واقعنا المعاصر (ص 237). }
$$

81- انظر : قطب. مذاهب فكرية معاصرة (ص 231) 181.179).

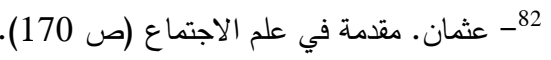

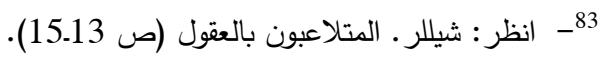

84- - انظر : جيمس. معنى الحقيقة (ص 22-21).

107 IUG Journal of Islamic Studies (Islamic University of Gaza) / CC BY 4.0 
4. المعايير والمقاييس: فقد تم تعطيل الثرع كمقياس للتصرفات والسلوكيات وأزيل سلطانه، فلم يبق للحلال والحرام مكان، وأمست

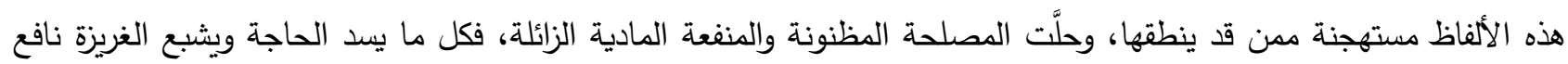

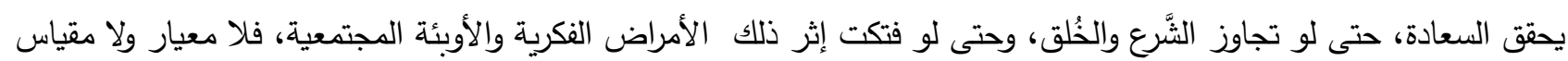
غير هوى النفس المتقلب الذي لا يعرف الثبات، وكان ذلك نتيجة تزيين المنكرات واستثارة الغرائز في وسائل الإعلام حتى أضحى الضى

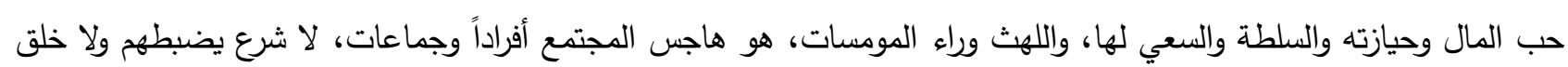

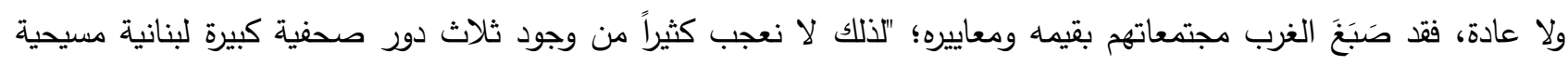
مارونية في القاهرة - ويفسر د. محمد قطب ذلك - أن الهدف كان ضرب الأزئ الزهر لكونه المركز الروحي والثقافي للمسلمين ليكون

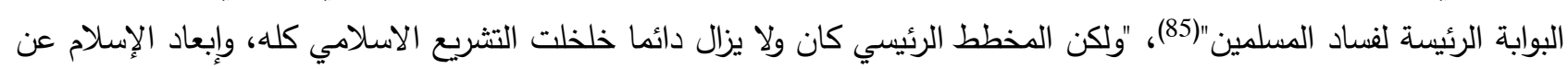
مركز القيادة وتوجيه الحياة السياسية والاقتصادية والاجتماعية للمسلمين"(86).

المسألة الرابعة: وظيفة الثقافة وأثرها في المجتمع. ويقصد هنا الثقافة السائدة لأن الثقافة الخاصة كما أسلفنا يكاد ينعدم أثرها في المجتمع لما للثقافة السائدة من سطوة

أولاً: وظيفة الثقافة في المجتمع:

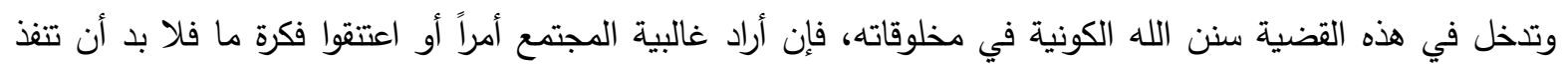

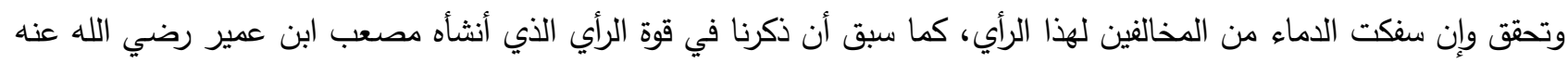
في المدينة حول الإسلام وأثره في استقبال النبي صلى الله عليه وسلم بالدفوف والأهازيج، رغم وجود المنافقين واليهود ومشركي

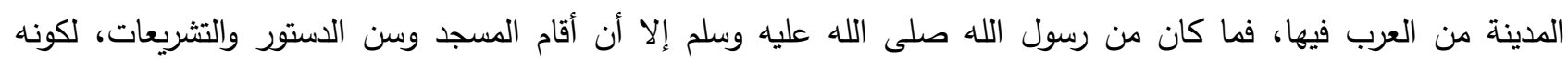

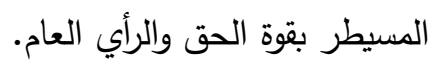

وقد سذَّر روَّاد الفكر الغربي من مبشرين ومستشرقين وسائل الإعلام في خدمتهم للتأثير على الرأي العام حتى يعمل عمله في المجتمع الإسلامي باعتباره المؤثر في ثقافة المجتمع وما ينتج عنها من نسق في العيش، كونها الحصن الحصين الحصني

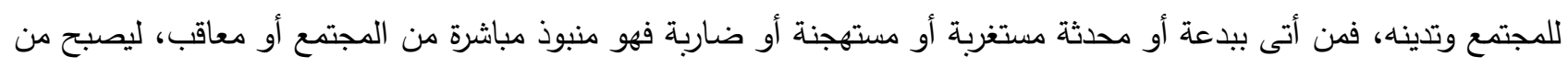

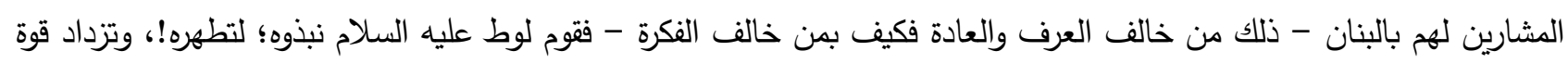

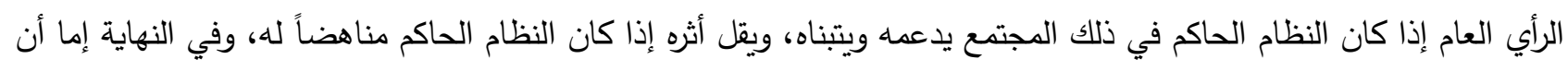

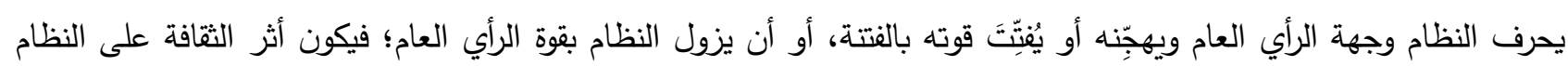

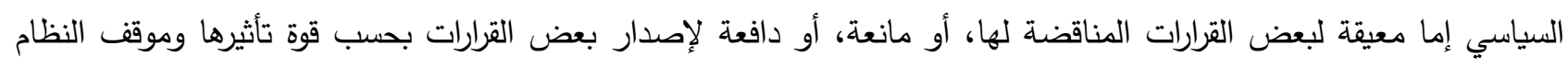

ثانياً: أثر التغير في الثقافة في المجتمع الإسلامي: يظهر أثر الثقافة على النظم والعلاقات الاجتماعية في السلوكيات والعادات والتقاليد والإنتاج الأدبي والفني لدى ألفئ ألفراد المجتمع وجماعاته، فهي تقوم بدورين رئيسين، الأول: محاكمة الأفكار ومحدثات المجتمع، والثاني: تعزيز الأفكار والقيم السائدة في المجتمع، فإذا ضَعُفت الثقافة وتزعزعت وتراجع دورها أضحى المجتمع نهاً لفاسد الأفكار والمعتقدات والقيم؛ دخلت هذه الأفكار في ثقافة المجتمع، ولكي تتضح الصورة؛ سنضرب بعض الأمثلة التي تبرز أثر التغير في الثقافة على نشاطات المجتمع وعلاقاته: 
1- مجال التصورات: أُِّفت الفنون والآداب التي تُككي من جذوة عالم الحس، والتي يبرز فيها الانبهار بما عند الغرب من أفكار،

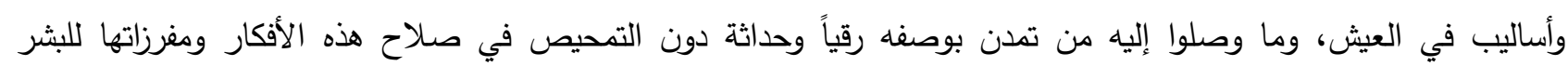

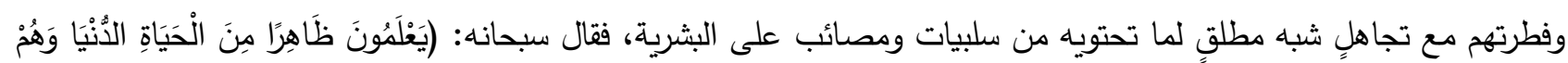

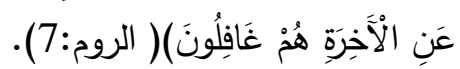

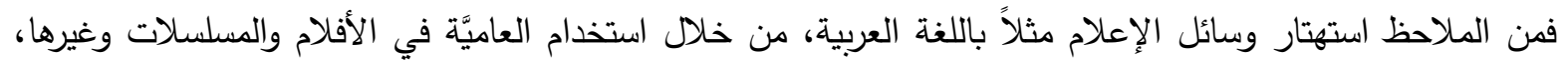

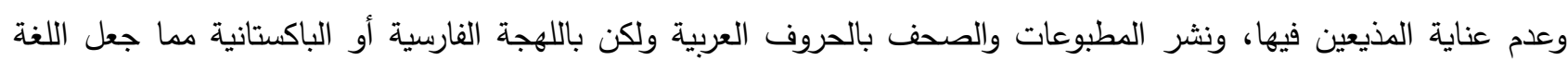

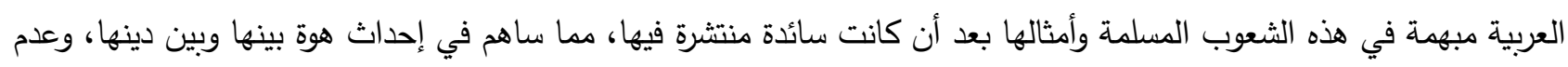
فهمها المباشر لكتاب ربها، وما يسود المجتمعات العربية من عُجمة بنطق اللغة العببية وفههها حتى بين النخب فيها، وتعثرهم في

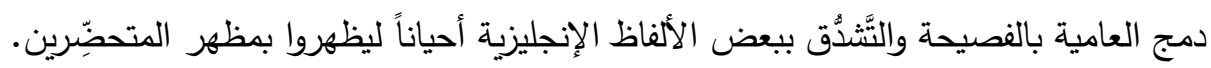

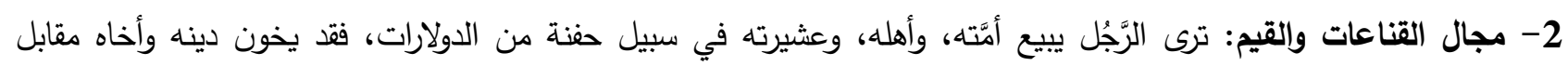

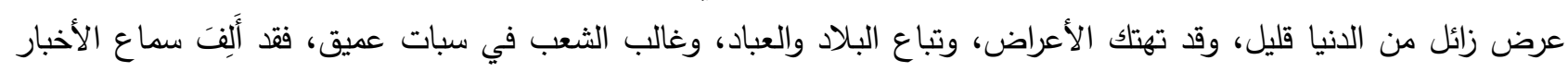

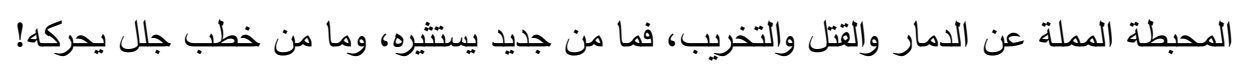

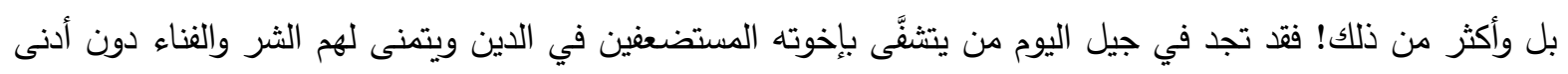
انتماء أو حمية بدعوى ضرورة السير في ركب الدول المتقدمة وهجر الموروث الموسوم بالرجعية، "ونثأ في أحضان هذا الإعلام بلإ

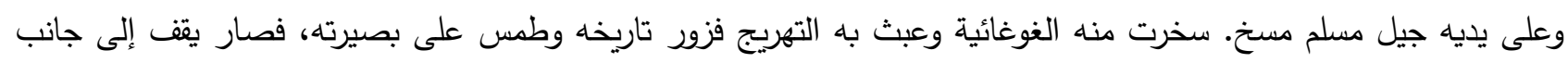

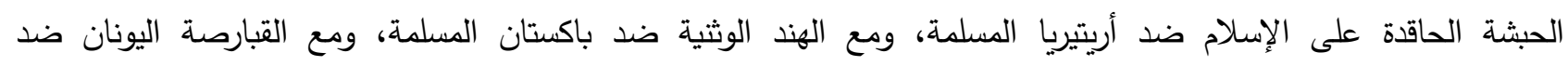
الأتراك...الخ"(87).

3- مجال النظم: فقد فُرضت علينا نُظمٌ وضعية ثُألَّهُ البشر ؛ فتستبدل حكم الله سبحانه بأهواء البشر، فخضع الجميع جهلاً وخوفاً، وربما طبَّل البعض لها وزمَّر، إما مغلوبين أو مسكورين بدعوى العصبيات، فساد الظلم والجور في كل النواحي؛ ففي الاقتصاد

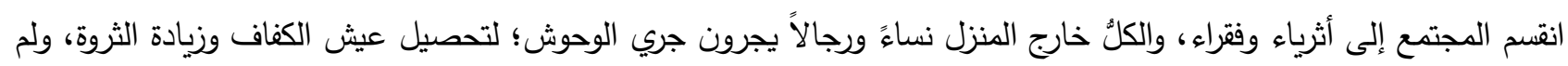

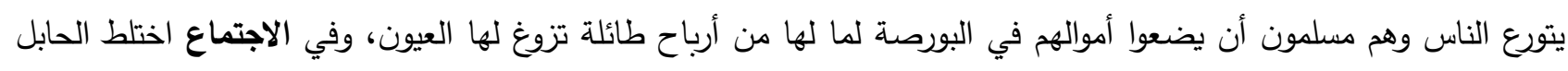

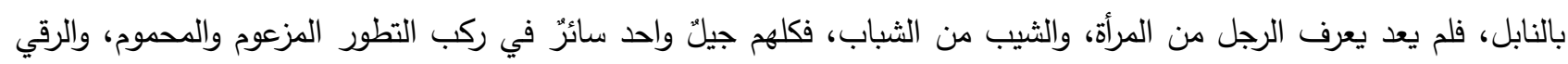
الكالح، فتفككت وانهارت الكثير من الأسر، وسادت الجريمة والرذيلة. وترى الأب فاقداً سلطته على زوجه وأبنائه بحجة الحقوق والحريات، وترى الابن يسب أباه وقد يضرببه دون خوف أو الوني

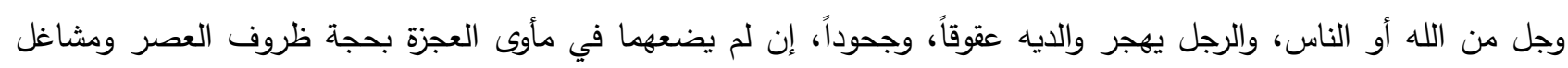
الحياة، وفي السياسة استبدل نظام الحكم الإسلامي بعد هدم الخلافة العثانية في بلاد الإسلام والمسلمين بالنظم الوضعية -

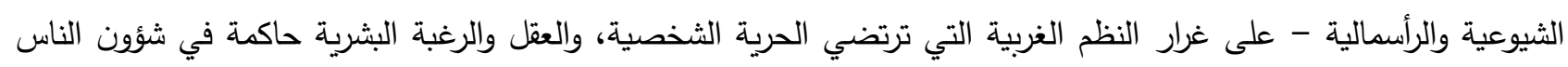

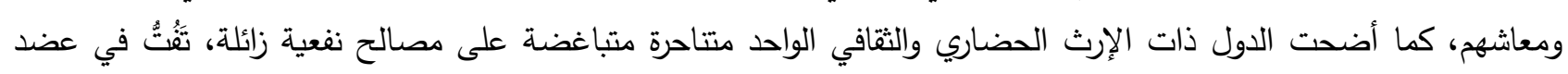
بعضها البعض، وتتآمر مع عدوها ضد نفهـا

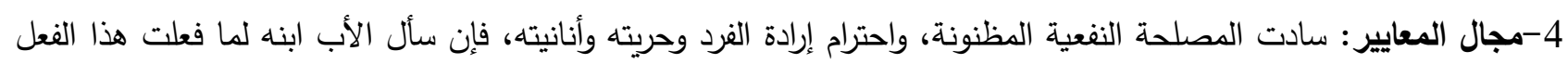

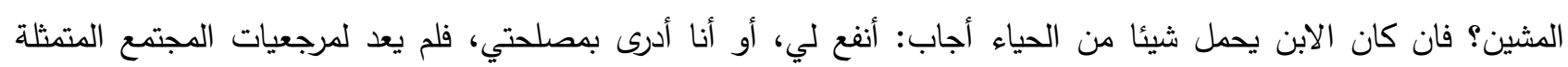

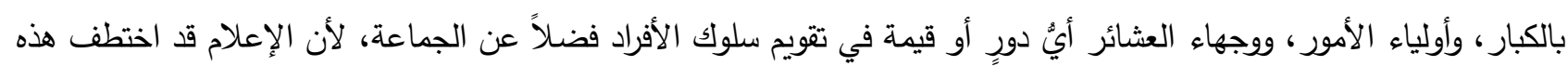
السلطة وسلبها إياهم بكل أسف. 
هذه باختصار شديد بعض الأمثلة في تحوّل السلوكيات والعلاقات في مجتمعاتتا، ولو أردنا الإسهاب في ذلك لألفت بذلك

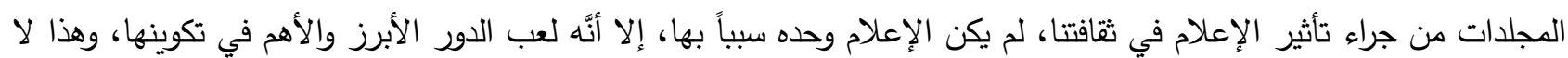

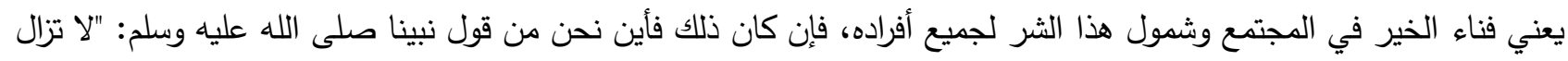

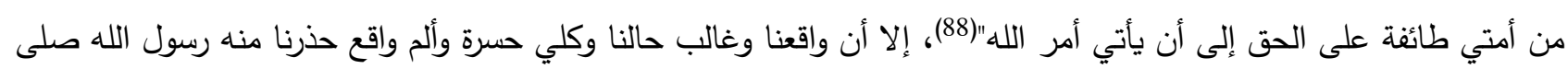

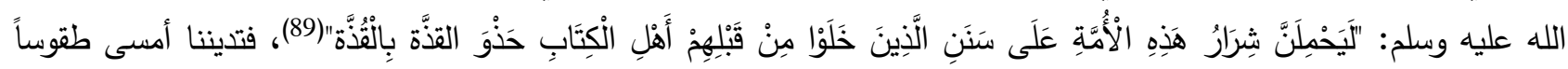

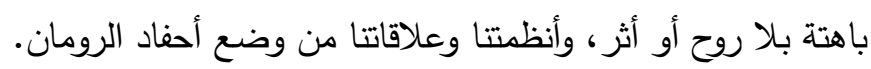

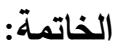
أولاً: أبرز النتائج: 1. تحليل تعريفات مصطلحات الدراسة ومناقشتها، وتحديد مفهومها وبيانه في الإسلام وغيره، والخروج ببعض التعريفات بما يخدم موضع الدراسة كمفهوم: الإعلام، والمجتمع، والرأي العام..الخ.

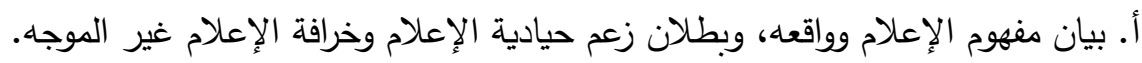

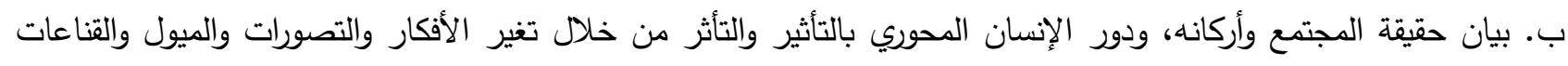
والنظم والمقاييس وتطبيقها فيه. ج. بيان مفهوم الرأي العام وتعريفه، ومدى تأثره بالإعلام ووسائله، ودوره المحوري في كيفية التغيير في الثقافة العامة للمجتمعات التئه

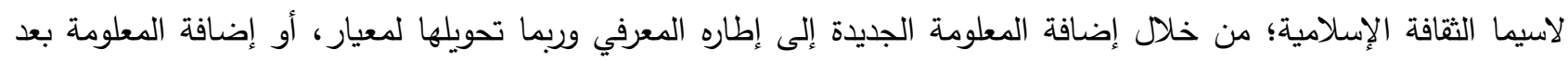

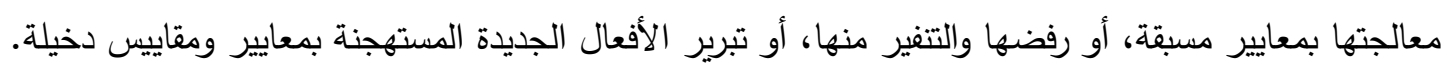

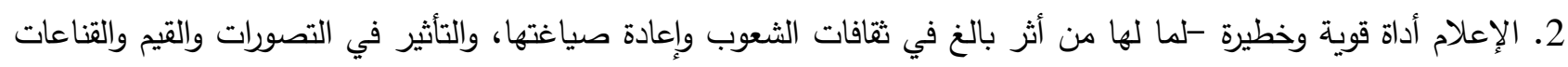
والميول والنظم-تخضع لأهداف القائمين عليها ومخططاتهم، ولابد من استغلالها في الخير ونشر الدعوة ودري الثبهات. 3. يستهدف الإعلام المعاصر -لمسيطر عليه من الغرب -الثقافة الإسلامية بجميع عناصرها سعياً لطمس هويتها وإعادة

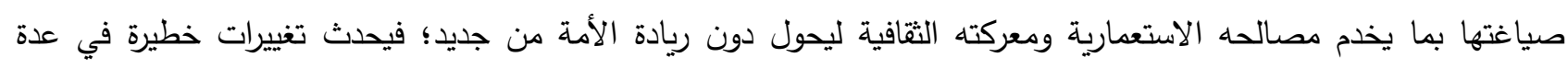

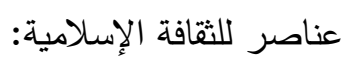
أ. التصورات والعقائد والأفكار : طغيان النزعة العلمانية في المجتمعات الإسلامية بفصل الدين عن واقع الحياة، وانتشار الثبهات المضللة، والنظر للدين والتدين كنوع من الرجعية والتخلف.

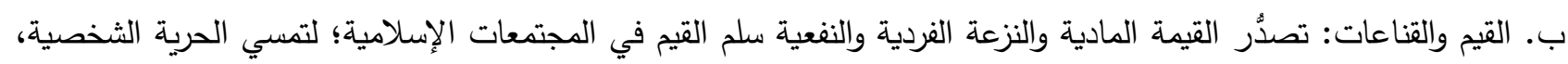
والمصلحة المظنونة، والسعادة البشرية رهينة إثباع الرغبات والمنافع المادية بديلاً عن رضا الله سبحانه والتزام أمره.

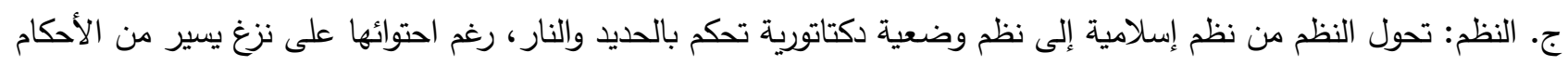
الثرعية في الزوجية والميراث، ففي مجال السياسة: حلت النظم الوضعية محل الخلافة الإسلامية - الجمهوري الديمقراطي -

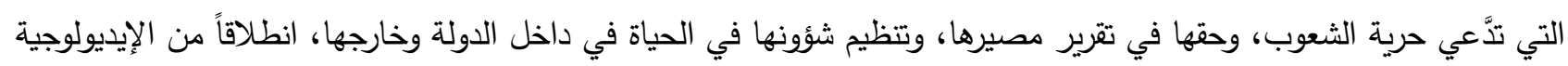

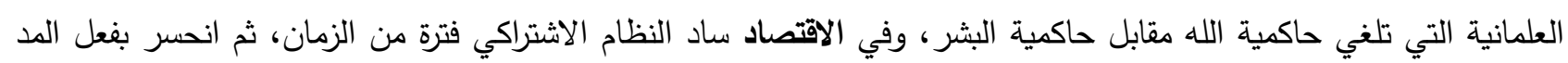

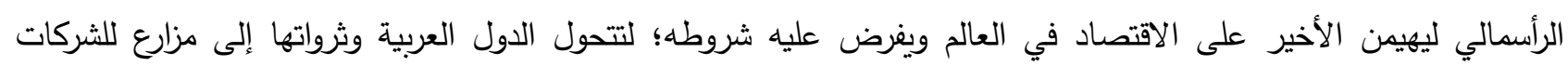

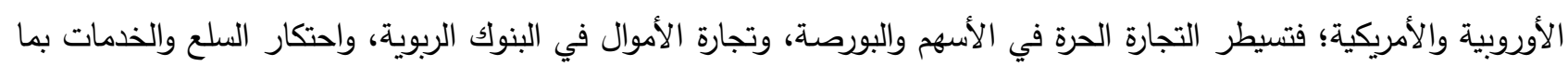
يسمى بحقوق الامتياز • وفي الاجتماع طغت فكرة الحرية الثخصية، وتضخمت الأنا الفردية على حساب النظم العشائرية والعائلية،

$$
\begin{aligned}
& \text { 88- البيضاوي. أنوار التنزيل وأسرار التأويل (ج2, ص341). }
\end{aligned}
$$

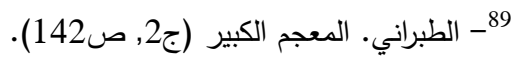

110 IUG Journal of Islamic Studies (Islamic University of Gaza) / CC BY 4.0 


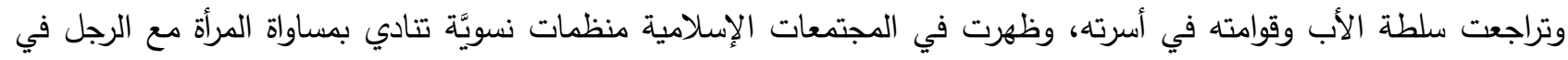
القوامة والميراث، وحقها في التحرر من سلطة الرجل والدين والعادات، وأخرى حقوقية تتادي بحقوق الإنسان في التحرر من قيود الدين والعادات والتقاليد، وتضغط على الدول لسن التشريعات، وفرض القوانين المبررة لتلك الدعوات الهدامة. د. المقاييس والمعايير: تعطيل الشرع كمقياس للأعمال والتصرفات، وتراجع قيمة الحلال والحرام في النفوس، واعتماد القوانين والوضعية المستندة للحرية الثخصية والنفعية كبديل لشرع الله سبحانه.

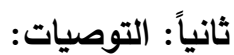

1. تأسيس أكاديميات خاصة بالإعلام الإسلامي الهادف؛ لإعداد إعلاميين مسلمين مخلصين منضبطين بأحكام الشرع الحنيف؛ ليكونوا كوادر في إعلامنا وصنَّاعَ قرارٍ فيه، يوجهوه وفق أمر الله وهدي رسوله صلى الله عليه وسلم.

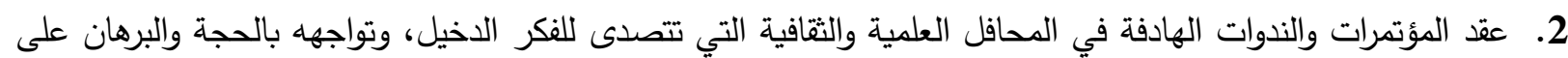
المستوى المحلي والعالمي. 3. تفعيل دور التواصل الثخصي من العلماء والدعاة في التوعية ونشر الدعوة، ودرء الثبهات من أذهان الواهمين والمضلَّلين من أبناء المسلمين.

\section{قائمة المراجع والمصادر}

ابن أبي شيبة، عبد الله. (1409هـ). الكتاب الدصنف في الأحاديث والآثار. (تحقيق: كمال يوسف الحوت). ط 1. الرياض: مكتبة الرشد.

ابن خلدون، عبد الرحمن. (د. ت). كتاب العبر وديوان المبتدأ والخبر الدعروف (بالهقدمة). (د. ط). (د. م). (د. ن).

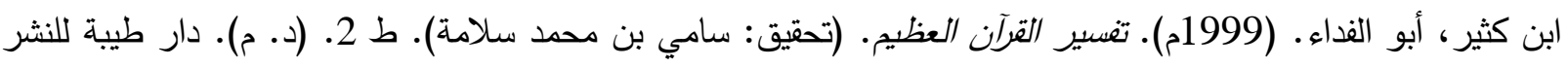
والتوزيع. ابن منظور ، محمد. (1414 هـ). لسان العرب. ط 3. 3. بيروت: دار صادر .

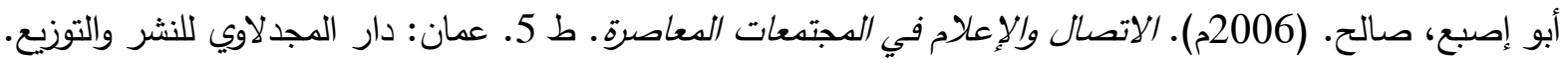
أبو زيد، فاروق. (2010م). الإعلام والديدراطية. ط 1 1. القاهرة: عالم الكتب.

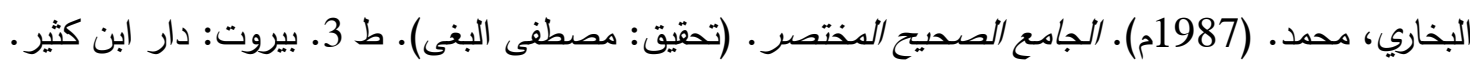
تثومسكي، ناعوم. (2003م). السيطرة على الإعلام. (ترجمة: أميمة عبد اللطيف). ط 1. القاهرة: مكتبة الثروق الدولية.

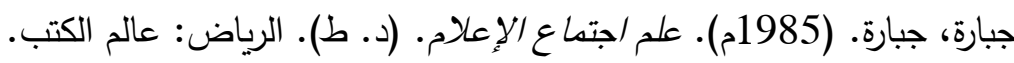

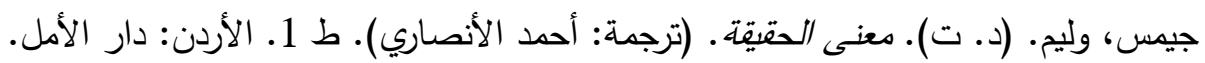

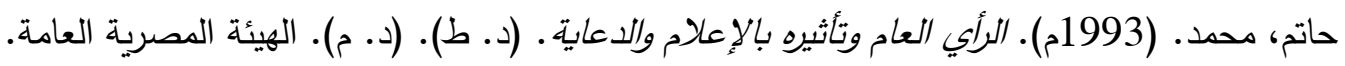

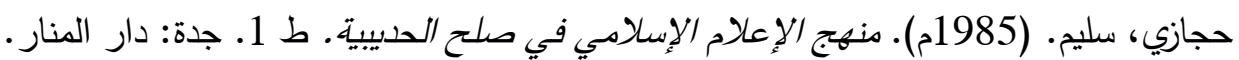

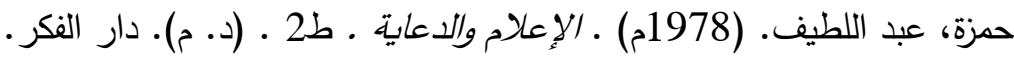
الحنفي، عبد المنعم. (د. ت). الدعجم الثامل لدصطلحات الفلسفة . (د. ط). (د. م) م). (د. ن) ن). الدبسي، عنان. (1990). الإعلام الإسلامي (الأهداف والوظائف). (د. ط). (د. م). دار العصماء. الدجني، يحيى. (2007م). الدعوة إلى الله أصولها ووسائلها وأساليبها. ط 2 2. غزَّة: مكتبة آفاق. الدميري، مصطفى. (1988م). الصحافة في ضوء الإسلام. (د. ط). مكة المكرمة: مكتبة الطالب الجامعي. 
رشوان، حسين عبد الحميد. (1997م). العلاقات العامة والإعلام من منظور علم الاجتماع. (د. ط). (د. م). الدكتب

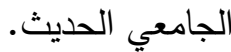

الساموك، سعدون. (2006م). في الهذ/هب الفكرية الدعاصرة. (د. ط). عمان: دار وائل للنشر .

سعد، إسماعيل. (1996م). الاتصال والئري العام. (د. ط). الإسكندرية: دار المعرفة الجامعية.

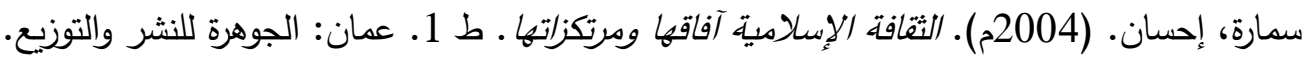
سمارة، إحسان. (2005م). مغاهيم أساسية في العقيدة الإسلامية. (د. طان). إربد: دار الكتاب الثقافي. شيللر، أ.هربرت. (1986م). المتلاعبون بالعقول. (ترجمة: عبد السلام رضوان). (د. ط). (د. م). المجلس الوطني للثقافة والفنون والأدب. عالم المعرفة. الطبراني، سليمان. (1983م). الدعجم الكبير. ط 2. (تحقيق: حمزة بن عبد المجيد السلفي). الموصل: مكتبة دار العلوم

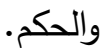
الطبري، ابن جرير • (2000م). جامع البيان في تأويل القرآن . (تحقيق: أحمد محمد شاكر ). ط 1. (د. م). مؤسسة الرسالة.

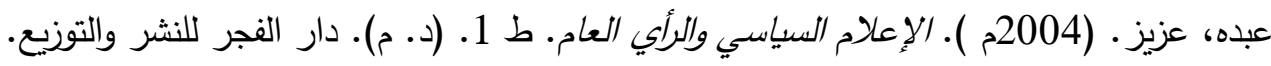

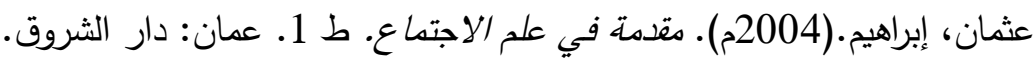

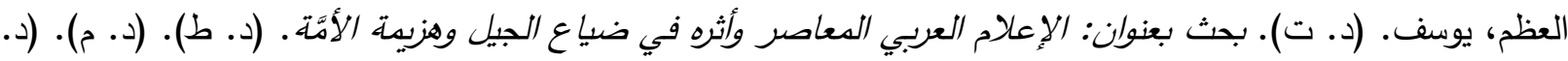

عودة، محمود. (د. ت). أساليب الاتصال والتغيير الجماعي. (د. ط). بيروت: دار النهضة العربية.

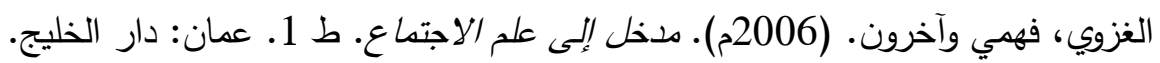

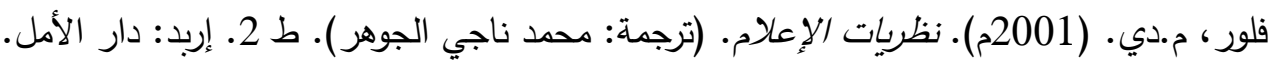
الفيروزبادي، مجد الدين. (2005م). القاموس المحيط. (تحقيق: مكتب تحقيق التراث في مؤسسة الرسالة). ط 8. مؤسسة الرسالة للطباعة والنشر والتوزيع. القاسم، خالد وآخرون. (2007) ). الددخل إلى الثقافة الإسلامية. . (د. ط). الرياض: جاضعة جامعة الملك سعود.

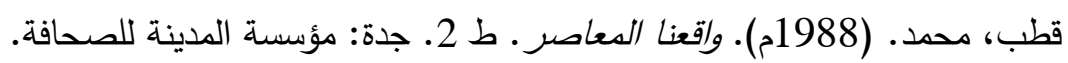
قطب، محمد. (2008م). مذاهب فكرية معاصرة. ط 10. القاهرة: دار الشروق.

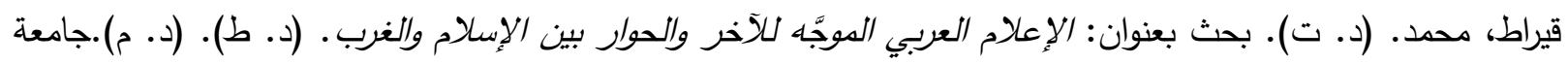

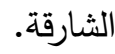
لبيضاوي، عبد الله. (1418هـ). أنوار التنزيل وأسرار التأويل. (تحقيق: محمد عبد الرحمن مرعشلي). ط 1. بيروت: دار إحياء التراث العربي. الماوردي، علي. (د. ت). النكت والعيون. (تحقيق: السيد ابن عبد المقصود بن عبد الرحيم). (د. ط). بيروت: دار الكتب

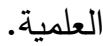
المصري، جميل. (1995م). الإسلام في مواجهة الحركات الفكرية زمن الدولة الأموية. (د. ط). الدار البيضاء: دار الثقافة.

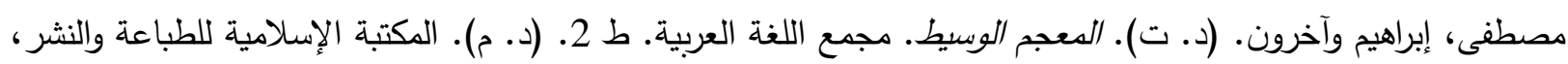
مجمع اللغة العربية. المطبقاني، حازم. (1995). الاستشراق والاتجاهات الفكرية في التاريخ الإسلامي (دراسة تطبيقية على كتاب برنارد لويس). (د. ط). الرياض: مكتبة الملك فهر الوطنية. 


$$
\begin{aligned}
& \text { منصور ، عصام. (2008م). دذخل إلى علم الاجتماع. ط 1. عمان: دار الخليج. } \\
& \text { الميداني، عبد الرحمن. (2000م). أجنحة الدكر الثلاثة وخوافيها: التبشير - الاستشراق - الاستعدار، دراسة تحليلية وتوجيه. }
\end{aligned}
$$

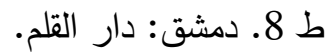

$$
\begin{aligned}
& \text { النبوي، نايف. (2001م). مدخل إلى علم الاجتماع. ط 1. عمان: دار الثروق. } \\
& \text { ندوة: (د. ت). نحو إعلام إسلامي فاعل ومؤثر،(د. ط)، (د. م). القيادة الثعبية الإسلامية العالمية. } \\
& \text { النسفي، عبد الله. (1998م). مدارك التنزيل وحقائق التأويل. (تحقيق: يوسف علي بديوي). ط 1. بيروت: دار الكلم } \\
& \text { الطيب. } \\
& \text { النيسابوري، مسلم.(د. ت). صحيح مسلم. (تحقيق: محمد فؤاد عبد الباقي). (د. ط) بيروت: دار إحياء التراث العربي. } \\
& \text { الهاشمي، مجد. (2001م). الإعلام الدولي والصحافة عبر الأقهار الصناعية. (د. ط). عمَان: دار المناهج. }
\end{aligned}
$$

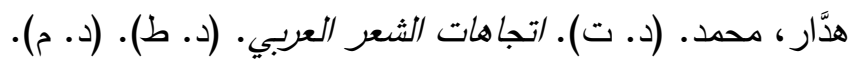

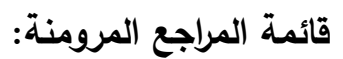

Ibn abi shaibah، A. (1409AH). AL- kitab AL-musannaf fi AL-hadith w aal-a' thar (in Arabic).(Edited by: kamal yousef AL-hout) .Riadh: AL-Rushd library.

IbnKhaldūn، A. Kitāb Al-'ibarWa-dīwān Al-mubtada'Wa-al-khabar (Almuqaddimah) (in Arabic) .

IbnKathir ، A. (1999 AD). Tafsir al-Qur'an al-'Azim (in Arabic). (edited by Sami bin Muhammad Salameh). Dar Taibah for publishing and distribution.

IbnManzūr، M. (1414 AH). Lisan Al-Arab (in Arabic). Beirut. Dar Sader.

Abu Isba'a، S. (2006 AD). Communication and media in contemporary societies (in Arabic). Amman: dar almajdalawi for publishing and distribution.

Abu Zaid، F. (2010 AD). Media and Democracy (in Arabic). Cairo: A'lamAlkutub.

Bukhari، M. (1987 AD). al-jami' al-sahih al-mukhtasar (in Arabic). (Edited by: Mustafa Albaghi).

Beirut: darIbnKathir.

Chomsky، N. (2003 AD). Media Control (in Arabic) (Umaimah. Abdullatif، trans.). Cairo: Alshorouq international library.

Jibara، J. (1985 AD). Sociology of media (in Arabic). Al-Riadh: A'lamAlkutub.

James، W. The meaning of truth (in Arabic). (Ahmad. Alansari، trans.). Jordan: Alamal for publishing.

Hatem، M. (1993 AD). Public opinion and its influence on the media and propaganda (in Arabic). Egyptian general staff.

Hijazi، S. "The method of islamic media in Al- hudaibiah conciliation" (in Arabic). Jiddah: Almanar for publishing.

Hamzeh، A. (1978 AD). Media and propaganda (in Arabic). Al-fikir for publishing.

Al-hanafi، A. The comprehensive dictionary of philosophy terms (in Arabic).

Aldibsi، A. (1990 AD). The Islamic media: Objectives and functions (in Arabic).Ala'sma'a for publishing.

Aldajani، Y. (2007 AD). Preaching: its origins، means، and methods (in Arabic). Gaza: A'faq library.

Aldimiri، M. (1988 AD). Journalism in the light of Islam (in Arabic). Mecca: University student library.

Rashwan' H. (1997 AD). Public relations and media in the perspective of sociology (in Arabic). The modern university office.

Alsamouk، S. (2006 AD). "Contemporary ideologies” (in Arabic). Amman: Wae'elfor publishing. 
Sa'ad‘I . (1996 AD). "Communication and public opinion" (in Arabic). Alexandria: alma'arifahaljamie'iiah for puplishing.

Samarah، E. (2004 AD). "The Islamic Culture: scope and principles (in Arabic).Amman: Aljawhara for publishing and distribution.

Samarah، E. (2005 AD). " Key concepts in the Islamic creed (in Arabic). Irbid: al-kitab al-thaqafi for publishing.

Schiller‘H. Mind managers (in Arabic). (Abdelsalam. Radwan‘ trans). National Council for Culture، Arts and Literature. A'alamalma'rifah.

Al-tabarani، S. (1983 AD). Mu'jam al-kabir (in Arabic). (edited by: Hamzeh bin Abdelmajid Alsalafi). Almosul: Alo'loumwaalhikam library for publishing.

Al- tabari، I. (2000 AD). Tafsir Al-tabari (in Arabic). (edited by: AhmahMuhammed Shaker). AlRisalah for publishing.

Abdo، A. (2004 AD). Political media and the public opinion (in Arabic). Vol1. Al-Fajir for publishing and distribution.

Othman' I. (2004 AD). Introduction to Sociology (in Arabic). Amman: Al-shorouq for publishing.

Al- Adhim- Y. published thesis: Contemporary Arabic media and its role in the generation loss and nation defeat (in Arabic).

Odeh، M. Communication methods and social change (in Arabic). Beirut: Al-nahda Al-arabiyyah for publishing.

Al- Gazwi، Fr et.al. (2006 AD). Introduction to Sociology (in Arabic). Amman: Al-khalij for publishing.

Fleure، M.D. (2001 AD).Communication theories (in Arabic). (Muhammed Naji Al-jawhar. Trans). Irbid: Al- Amal for publishing.

Alfirouza'badi، M. (2005 AD). Al- Qamous Al- Muheet (in Arabic) . ( edited by: Al- Turath in AlRisalah association. Beirut: Al-Risalahfor print، publishing، and distribution.

Al-Qasem، Khalid، et.al. (2007 AD). Introduction to Islamic Culture (in Arabic). Al-Riadh: King Saud University.

Qutub، M. (1988 AD). Our Contemporary reality (in Arabic). Jeddah: Al-Madina association for journalism.

Qutub، M. (2008 AD). Contemporary Ideologies (in Arabic). Cairo: Al-Shorouq for publishing.

Qirat· M. Published thesis: Arabic media oriented to the others and the dialogue between Islam and the West (in Arabic). Al-Shariqa University.

Al-Baidawi، A. (1418 AH). Anwar Al-tanzil wa Asrar al-ta'weel. (edited by: Muhammed Abdulrahman Mara'ashly). Beirut: Ehia'a Al-turath Al-araby for publishing.

Al-Maroudy، Ali. Jokes and Eyes (in Arabic). (edited by: Said bin Abdelmaqsoud bin Abdelrahim).

Beirut: Al-kutub Al-e'lmeiah for publishing.

Al-masri، J. (1995 AD). Islam against ideologies in the time of Umayyad State (in Arabic). Casablanca: Al-thaqafa for publishing.

Mustafa، I، et.al. ). Mu'jam al-waseet.Arabic Language Academy(in Arabic). Islamic library for print and publishing، Arabic language Academy.

Al-matbaqani، H. (1995 AD). Orientalism and intellectual orientations in the Islamic history (in Arabic). (Application study on Bernard Lewis' book). Al-Riadh: King Fahd national library.

Mansour، I. (2008 AD). Introduction to Sociology (in Arabic). Amman: Al-khalij for publishing.

Al-maidani، A. (2000 AD). the triple suites of deceit and their secrets: evangelization، orientalism، colonialism، analytical study (in Arabic). Demascus: Al-qalam for publishing.

Al-nabawi، N. (2001 AD). Introduction to Sociology (in Arabic). Amman: Al-Shorouq for publishing.

Conference: Towards an effective and influential Islamic media (in Arabic). The Global Islamic Popular Leadership. 
Al-nasfi ، A. (1998 AD). Madarek Al-tanzeel wa Haqae'q al-ta'weel (in Arabic). (edited by: Yousef Ali Bdeiwi). Beirut: Al-kalim Al-taiieb for publishing.

Al-neisaburi، M. Sahih Muslim (in Arabic). (edited by: Muhammed Fuad Abdulbaqi). Beirut: Ehia'a Al-turath Al-araby for publishing.

Al-hashmi، M. (2001 AD). Journalism and international media across satelites (in Arabic). Amman: Al-manahej for publishing.

Haddar‘ M. Arabic poetry trends (in Arabic). 